\title{
ESTUDO DAS TRANSFORMAÇÕES NA CONFORMAÇÃO DOS MACIÇOS ARBÓREO/ARBUSTIVOS DO PARQUE DA ESCOLA SUPERIOR DE AGRICULTURA "LUIZ DE QUEIROZ” - UNIVERSIDADE DE SÃO PAULO, ATRAVÉS DE FOTOGRAFIAS AÉREAS VERTICAIS E LEVANTAMENTOS FLORÍSTICOS DE ÉPOCAS DISTINTAS.
}

Henrique Sundfeld Barbin

\author{
Dissertação apresentada à Escola Superior de \\ Agricultura “Luiz de Queiroz”, Universidade de São \\ Paulo, para obtenção do título de Mestre em \\ Agronomia, Área de concentração: Fitotecnia.
}

PIRACICABA

Estado de São Paulo - Brasil

Julho de 1999 


\title{
ESTUDO DAS TRANSFORMAÇÕES NA CONFORMAÇÃO DOS MACIÇOS ARBÓREO/ARBUSTIVOS DO PARQUE DA ESCOLA SUPERIOR DE AGRICULTURA “LUIZ DE QUEIROZ” - UNIVERSIDADE DE SÃO PAULO, ATRAVÉS DE FOTOGRAFIAS AÉREAS VERTICAIS E LEVANTAMENTOS FLORÍSTICOS DE ÉPOCAS DISTINTAS.
}

\section{HENRIQUE SUNDFELD BARBIN}

Engenheiro Agrônomo

Orientador: Prof. Dr. VALDEMAR ANTONIO DEMÉTRIO

\author{
Dissertação apresentada à Escola Superior de \\ Agricultura “Luiz de Queiroz”, Universidade de São \\ Paulo, para obtenção do título de Mestre em \\ Agronomia, Área de concentração: Fitotecnia.
}

PIRACICABA

Estado de São Paulo - Brasil

Julho de 1999 
Dados Internacionais de Catalogação na Publicação (CIP) DIVISÃO DE BIBLIOTECA E DOCUMENTAÇÃO - Campus “Luiz de Queiroz"IUSP

Barbin, Henrique Sundfeld

Estudo das transformações na conformação dos maciços arbóreo/arbustivos do Parque da Escola Superior de Agricultura "Luiz de Queiroz" universidade de São Paulo, através de fotografias aéreas verticais e levantamentos florísticos de épocas distintas / Henrique Sundfeld Barbin. - - Piracicaba, 1999.

94 p. : il.

Dissertação (mestrado) - - Escola Superior de Agricultura Luiz de Queiroz, 1999.

Bibliografia.

1. Cronologia 2. Composição Florística 3. Fotografia aérea 4. Fotointerpretação 5. Geoprocessamento 6. Paisagismo 7. Parque da ESALQ 8. SIG - IDRISI I. Título

CDD 634.9

\section{“Permitida a cópia total ou parcial deste documento, desde que citada a fonte - O autor”}


Aos meus pais

Décio e Bernadete

Ao meu irmão e cunhada

Alexandre e Giselis

\section{À sobrinha}

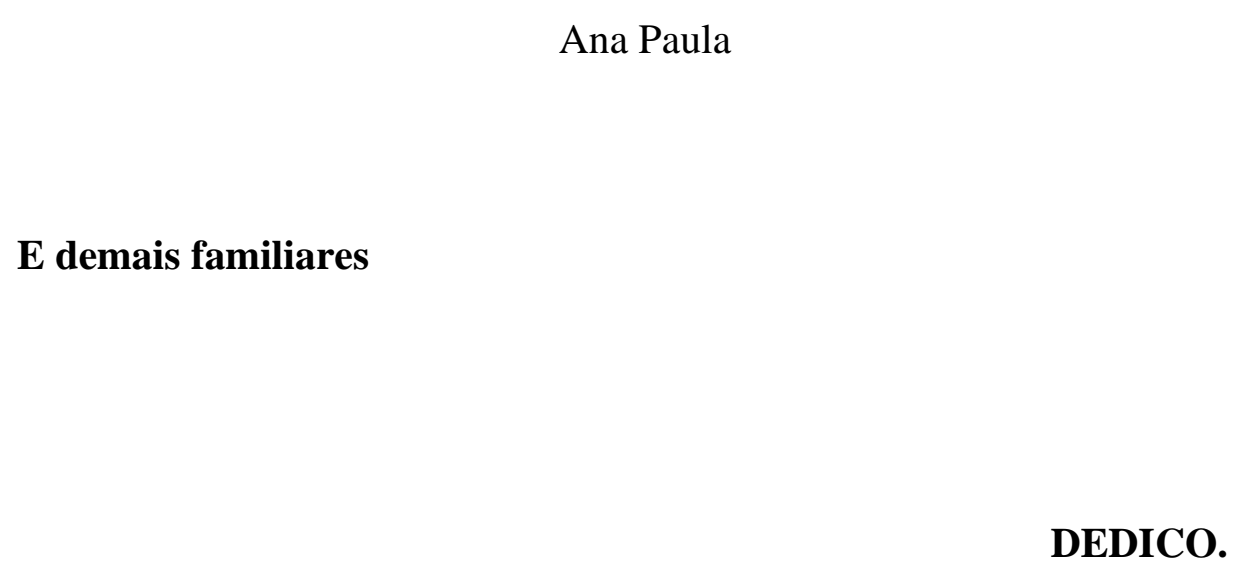




\section{AGRADECIMENTOS}

Ao meu Orientador Prof. Dr. Valdemar Antonio Demétrio, a amizade, dedicação e confiança em mim depositada;

Aos integrantes da Banca Examinadora da Dissertação: Prof. Dr. Valdemar Antonio Demétrio, Prof. Dr. Roberval de Cássia S. Ribeiro e Prof Dr. Hilton Thadeu Z. do Couto, bem como os Suplentes: Prof. Dr. Keigo Minami e Prof ${ }^{a}$ Dr $^{a}$ Maria Esmeralda S. Payão Demattê.

Aos integrantes da Banca Examinadora da Qualificação nas pessoas de: Prof. Dr. João Tessarioli Neto, Prof. Dr. João Alexio Scarpari Filho e Prof. Dr. Valdemar Antonio Demétrio;

À Comissão de Pós-graduação do curso de Fitotecnia da ESALQ/USP, a oportunidade concedida;

À Coordenadoria de Aperfeiçoamento de Ensino Superior (CAPES), pela concessão da bolsa de estudos;

À Prof ${ }^{\mathrm{a}}$. Dra . Maria Esmeralda Soares Payão Demattê, a amizade, carinho, admiração e introdução ao ramo de paisagismo;

Ao Eng. Agr. Rodolfo Ricardo Geiser, pela amizade, as oportunidades concedidas e o apoio na realização deste trabalho;

Aos professores, funcionários e pós-graduandos do Departamento de Produção Vegetal, a amizade e ajuda prestada;

Aos professores, funcionários, pós-graduandos e estagiários do Engenharia Rural, a amizade, convivência e ajuda dispensada;

Aos professores e funcionários do Departamento de Ciências Exatas, a amizade e auxílios;

Aos professores do Departamento de Botânica, a ajuda prestada;

Aos meus amigos, que de uma forma ou de outra me apoiaram neste trabalho;

À Gráfica da Unimep, a amizade, ajuda e qualidade nos serviços prestados;

Aos que participaram no desenvolvimento da dissertação, nas pessoas de: Silvio Frosin de Barros Ferraz, Jesuíno Ferrari, Anderson L. do Nascimento, Prof ${ }^{a}$. Dr ${ }^{a}$. Ana 
Maria L. P. Lima, Eng. Agr. Marcelo Crestana, Jorge A. Wiedl, José Mário Frasson Scafi, Prof. Dr. Carlos Alberto Vettorazzi, Prof. Dr. Rubens Angulo Filho, Prof. Ms. Jorge G. da Graça Raffo, Prof . Dr $^{\mathrm{a}}$. Clarice G. B. Demétrio, Debora Nunho Giandoni; Valter Antônio Milanez, Eliana Sabino, Daniela G. B. Demétrio, dentre outros. 


\section{SUMÁRIO}

Páginas

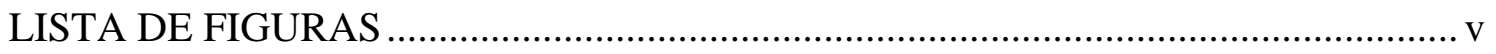

LISTA DE TABELAS .................................................................................... ix

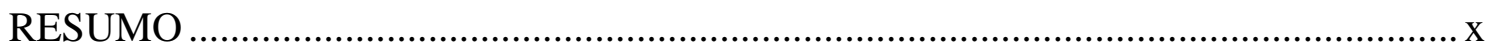

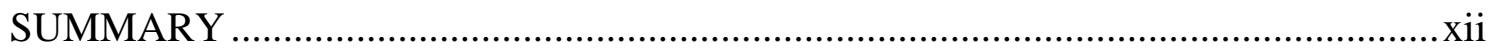

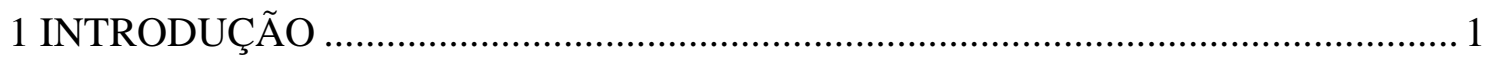

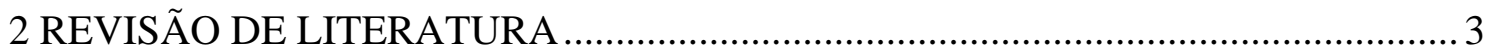

2.1 Estilo de Jardim Inglês ...................................................................................... 3

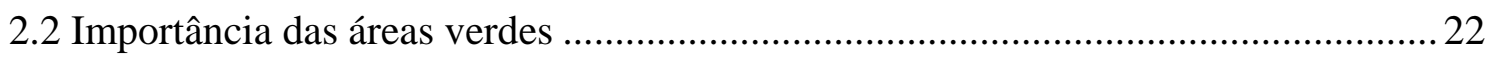

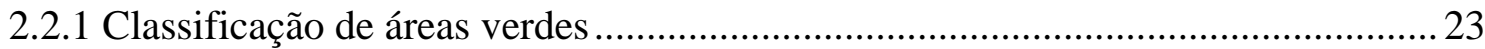

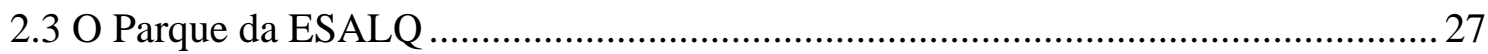

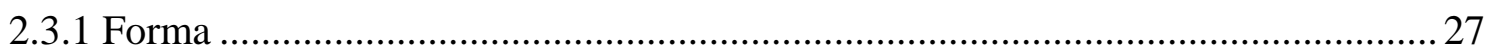

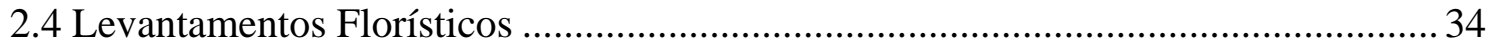

2.5 Fotointerpretação e Técnicas Cartográficas .......................................................... 37

2.6 Sistemas de Informações Geográficas (SIG) ..................................................... 42

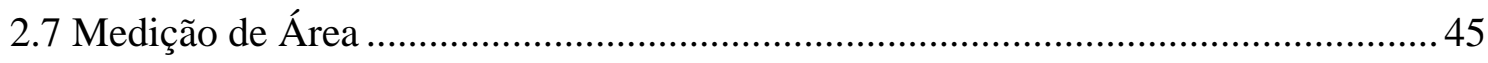

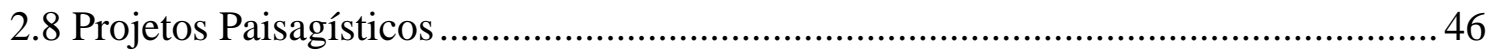

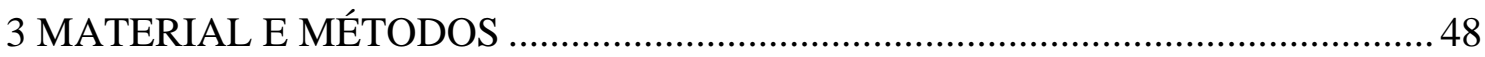

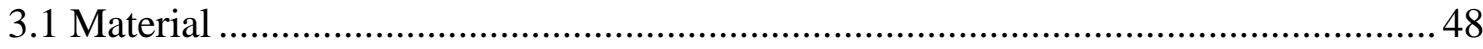

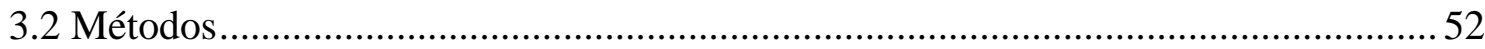

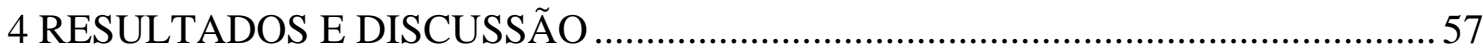

4.1 Descaracterização da Área de Cobertura Arbórea ................................................. 57

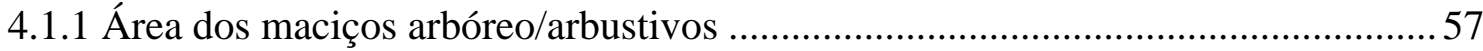

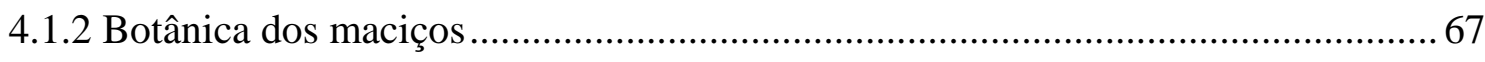

4.1.3 Espécies ornamentais de pequeno porte....................................................... 78

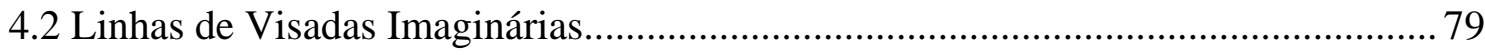

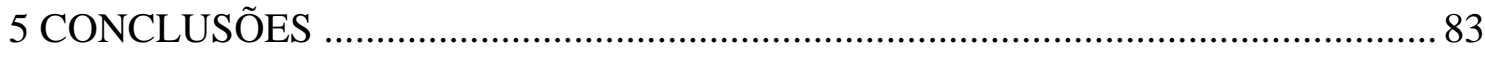

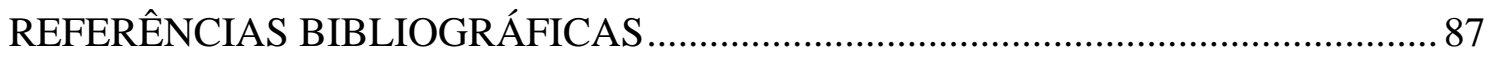




\section{LISTA DE FIGURAS}

Página

1 Desenho mostrando as alamedas: larga (côncava) e a estreita (plana) .......................... 7

2 Projeto paisagístico no Estilo Inglês, mostrando as alamedas

principais mais largas e as secundárias, mais estreitas ........................................ 7

3 Fotografia do Parque da ESALQ, tirada na década de 50,

ilustrando uma alameda desprovida de pavimento ............................................... .8

4 Desenho mostrando como deve ser a bifurcação de duas

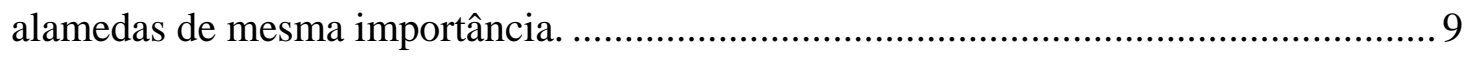

5 Desenho mostrando como deve ser a bifurcação entre uma alameda principal e uma secundária. A guia A, é da alameda

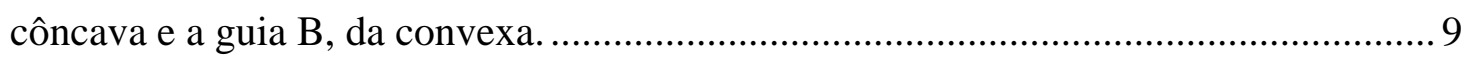

6 Desenho mostrando como deve ser a bifurcação entre uma

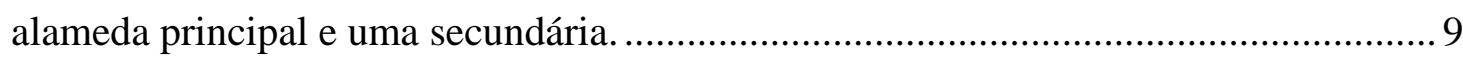

7 Desenho mostrando a entrada de um parque ladeada

por maciços arbóreos.

8 Desenho mostrando o ângulo de visão que a segurança do parque deve ter para evitar a entrada de pessoas onde $\mathrm{H}$, é a edificação; C, é o gramado existente entre os portões de entrada e L, é o local de visão da segurança 11

9 Desenho mostrando como deve ser o relevo do gramado principal. Onde as linhas AE, CD, FE e GE, delimitam os declives e E é a cota mais baixa do vale 12 
Página

10 Desenho mostrando a borda do maciço recortada, (desenho à esquerda) e arredondada (desenho à direita). 14

11 Desenhos mostrando as várias maneiras de distribuir regularmente as árvores. 15

12 Desenhos mostrando as várias maneiras de distribuir irregularmente as árvores onde T, representa 3 árvores; $\mathrm{K}$, para 4; C, para 5 e S para 7................... 16

13 Desenho mostrando como se deve dispor as árvores, para direcionar as linhas de vista.

14 Desenho mostrando como se deve distribuir o canteiro de flores na frente da edificação. 18

15 Projeto Paisagístico de Parque para a Praça de São Bento, em Niterói-RJ, elaborado por Arsenio Puttemans. 20

16 Projeto Paisagístico de um parque no Estilo Inglês de Paisagismo. 21

17 Fotografia ilustrando o maciço 13, logo após a sua implantação .28

18 Fotografia ilustrando o maciço 9, logo após a sua implantação. 28

19 Desenho do Projeto Original do Parque da ESALQ visto em perspectiva 30

20 Planta baixa ilustrando a área total do Parque. No destaque pode se observar a área projetada originalmente. .31 
Página

21 Fotografia ilustrando a troca de solo na implantação do Parque por volta de 1906 33

22 Mapa com os prédios e os nomes das ruas que delimitam o Parque e os números dos maciços arbóreo/arbustivos estudados. 49

23 Planta baixa mostrando o relevo do Parque. 50

24 Projeto Original do Parque da ESALQ. 51

25 Mapa contendo os maciços arbóreo/arbustivos, as linhas de visada imaginárias obstruídas (linhas vermelhas), as desobstruídas (linhas azuis) e os prédios. 55

26 Planta baixa do Projeto Original com layer contendo os maciços apresentados na fotografia aérea de 1995 59

27 Fotografia do Parque da ESALQ, mostrando árvores plantadas com espaçamento maior, com o intuito de não formação de maciço, conforme o projetado por Puttemans 60

28 Gráfico da equação de regressão linear ajustada e dados observados. 61

29 Fotoimagem ressaltando os maciços arbóreo/arbustivos presentes na fotografia aérea de 1962, (áreas coloridas) sobreposto por layer elaborado na digitalização da fotografia aérea de 1945 (contornos em preto). 63

30 Fotoimagem ressaltando os maciços arbóreo/arbustivos presentes na fotografia aérea de 1969, (áreas coloridas) sobreposto por layer elaborado na digitalização da fotografia aérea de 1962 (contornos em preto). 
Página

31 Fotoimagem ressaltando os maciços arbóreo/arbustivos presentes na fotografia aérea de 1973, (áreas coloridas) sobreposto por layer elaborado na digitalização da fotografia aérea de 1969 (contornos em preto). 64

32 Fotoimagem ressaltando os maciços arbóreo/arbustivos presentes na fotografia aérea de 1993, (áreas coloridas) sobreposto por layer elaborado na digitalização da fotografia aérea de 1973 (contornos em preto). 64

33 Fotoimagem ressaltando os maciços arbóreo/arbustivos presentes na fotografia aérea de 1995, (áreas coloridas) sobreposto por layer elaborado na digitalização da fotografia aérea de 1993 (contornos em preto).

34 Fotoimagem ressaltando os maciços arbóreo/arbustivos presentes na fotografia aérea de 1995, (áreas coloridas) sobreposto por layer elaborado na digitalização da fotografia aérea de 1945 (contornos em preto), sendo, portanto a maior amplitude, em anos, estudada. 65

35 Foto ilustrando uma muda de árvore que foi plantada no perímetro do maciço número 7 66

36 Foto ilustrando uma muda de árvore que nasceu espontaneamente sob área sombreada no perímetro do maciço número 11 67

37 Imagem mostrando as linhas de visada obstruídas (linhas vermelhas), os maciços 17, 18, os mini-maciços 24c e 24g e o Prédio da Seção de Alunos, que interrompem as linhas. 80 


\section{LISTA DE TABELAS}

1 Área de cada maciço arbóreo/arbustivo $\left(\mathrm{em} \mathrm{m}^{2}\right.$ ), nos anos investigados

Página

e no projeto original, calculada por meio do software IDRISI 58

2 Razão de Crescimento dos maciços arbóreo/arbustivos do Parque.

3 Lista do levantamento florístico, realizado em 1965, das espécies vegetais arbóreas e arbustivas encontradas em parte do Parque (maciço 1 ao 22) e o número de exemplares de cada espécie 68

4 Lista do levantamento florístico, realizado em 1991, das espécies vegetais arbóreas e arbustivas encontradas em parte do Parque (maciço 1 ao 22) e o número de exemplares de cada espécie

5 Lista das espécies arbóreas e arbustivas que foram extintas do Parque no período estudado. 73

6 Lista das espécies arbóreas e arbustivas incorporadas ao

Parque no período estudado. 75

7 Lista das espécies arbóreas e arbustivas que aparecem no levantamento de 1965 e no de 1991 76

8 Lista com as espécies ornamentais de pequeno porte, presentes no Parque, segundo o levantamento florístico realizado em 1965 78

9 Lista com as espécies ornamentais de pequeno porte, presentes no Parque através de cadastro realizado in loco, em agosto de 1998 


\title{
ESTUDO DAS TRANSFORMAÇÕES NA CONFORMAÇÃO DOS MACIÇOS ARBÓREO/ARBUSTIVOS DO PARQUE DA ESCOLA SUPERIOR DE AGRICULTURA “LUIZ DE QUEIROZ” - UNIVERSIDADE DE SÃO PAULO, ATRAVÉS DE FOTOGRAFIAS AÉREAS VERTICAIS E LEVANTAMENTOS FLORÍSTICOS DE ÉPOCAS DISTINTAS.
}

\author{
Autor: HENRIQUE SUNDFELD BARBIN \\ Orientador: Prof. Dr. VALDEMAR ANTONIO DEMÉTRIO
}

\section{RESUMO}

No presente estudo, utilizaram-se de fotografias aéreas verticais e levantamentos florísticos de épocas distintas, para acompanhar as transformações ocorridas nos maciços vegetais do Parque da Escola Superior de Agricultura "Luiz de Queiroz" (ESALQ), da Universidade de São Paulo (USP), em Piracicaba. O Parque, de 15.000 m², construído no Estilo Inglês de Paisagismo, foi implantado ao redor de 1907 e teve crescimento descontrolado e demasiado das áreas de seus maciços arbóreo/arbustivos, comprovado pela análise de fotografias aéreas verticais a partir do ano de 1945, que mostram o aumento em área dos referidos maciços propostos no projeto original. Nos projetos paisagísticos, considera-se a média de vinte anos, para que a cobertura florística atinja os limites representados geograficamente, desde que na implantação, a escolha de espécies, plantios, condições edafo-climáticas, tratos culturais etc, também sejam contempladas no planejamento. Usando-se o software IDRISI, fotografias aéreas verticais dos anos 1945, 1962, 1969, 1973, 1993 e 1995 e o projeto original do Parque, calculou-se a área de cada um dos 24 maciços vegetais presentes no Parque, nos diferentes anos e estas foram confrontadas. Os resultados mostram um grande crescimento dos maciços, uma vez que o somatório das áreas dos mesmos, projetados em 1907, perfazem um total de $28.641 \mathrm{~m}^{2}$ de cobertura arbórea, prevista para 1927, vinte anos após a sua concepção, medidas estas que deveriam ser mantidas. Em 1945, o somatório de suas áreas já perfaziam $40.576 \mathrm{~m}^{2}$, portanto $11.935 \mathrm{~m}^{2}$ além do projetado inicialmente (1907) e em 1995 (última fotografia obtida), a área de cobertura arbórea era de $77.221 \mathrm{~m}^{2}$, portanto mais da metade $(51,5 \%)$ da área total do Parque $\left(150.000 \mathrm{~m}^{2}\right)$ e 
ainda, $170 \%$ a mais de cobertura arbórea do que o projetado inicialmente. No período de 1945 a 1995, o incremento arbóreo foi de $36.655 \mathrm{~m}^{2}$, praticamente dobrando a área total de cobertura.

Levando-se em consideração os anos de 1945 e 1995 (maior amplitude, em anos, deste estudo), os maciços cresceram, em área, praticamente na mesma proporção, sendo estas ajustadas a uma reta.

Uma das características importantes do Estilo Inglês de Paisagismo, são as linhas de visada que ressaltam pontos de interesse, como edificações, árvores exóticas e outros. No projeto original do Parque da ESALQ, foram planejadas dez linhas de visada. Em 1995, seis dessas linhas estavam obstruídas pelo crescimento não planejado dos maciços e também pela construção de um prédio em área do Parque. Destas, quatro podem ser desobstruídas, através de práticas simples de manejo e as outras duas, ficam impossibilitadas de desobstrução devido à presença do referido prédio.

Quanto ao estudo dos levantamentos florísticos de parte dos maciços arbóreo/arbustivos (do maciço de número 1 ao de número 22), realizados no Parque nos anos de 1965 e 1991, os mesmos foram digitados no software Access. Pelo levantamento florístico realizado em 1965, constata-se que o Parque era formado por 444 indivíduos arbóreo/arbustivos, sendo este valor aumentado para 2.904, segundo o levantamento florístico realizado em 1991. Com relação às espécies arbóreas e arbustivas encontradas, em 1965, no Parque existiam 241 espécies, número este, diminuído em 1991, para 215 espécies. Nota-se ainda, grande domínio em número de indivíduos, de algumas espécies sobre outras e a formação de reboleiras de algumas espécies. Ainda sobre os levantamentos florísticos, através de confrontos realizados, utilizando-se do software Access e os respectivos levantamentos, nota-se, a extinção de 154 espécies arbóreo/arbustivas e incremento de outras 124, estando apenas 90 espécies, presentes nos dois levantamentos (1965 e 1991).

Todos estes fatos apresentados, indicam a necessidade de um manejo adequado urgente dos maciços vegetais do Parque da ESALQ, para evitar maior descaracterização do mesmo. 


\title{
STUDY OF THE TRANSFORMATIONS IN DISPLAY OF ARBOREAL/SHRUBS MASSES OF THE PARK OF THE ESCOLA SUPERIOR DE AGRICULTURA " LUIZ DE QUEIROZ " USING VERTICAL AERIAL PICTURES AND FLORÍSTICS SURVEYS OF DIFFERENT TIMES
}

\author{
Author: HENRIQUE SUNDFELD BARBIN \\ Adviser: Prof. Dr. VALDEMAR ANTONIO DEMÉTRIO
}

\section{SUMMARY}

In the present study, vertical aerial pictures and floristic surveys from different times were used to assess the transformations on plant masses of the Park of Escola Superior de Agricultura "Luiz de Queiroz " (ESALQ), Universidade of São Paulo (USP), in Piracicaba - SP - Brazil. The Park, comprised of $15.000 \mathrm{~m}^{2}$, was built in the English Landscape Style, near 1907 and has had ever since too much uncontrolled growth of arboreal/shrubby masses, as determined by the analysis of vertical aerial pictures in 1945. In the large seales landscape projects it is expected twenty years for the plant mass to reach its peak, considering that the choice of species, planting, edafoclimatic conditions, cultural treatments etc are also regarded in the planning. The area of the 24 masses existents on the Park was calculated on different years and compared, using software IDRISI, vertical aerial pictures of 1945, 1962, 1969, 1973, 1993 and 1995 as well as the original project of the Park. The results show excess of growth of the plant mass. In 1907 the total area of the added $28.641 \mathrm{~m}^{2}$. As foreseen for 1927, twenty years after its conception, such measurements should remain the same. In 1945, these areas added $40.576 \mathrm{~m}^{2}$ (11.935 $\mathrm{m}^{2}$ above the original project); and in 1995 (last obtained picture), the area of arboreal covering was of $77.221 \mathrm{~m}^{2}$, more than half $(51,5 \%)$ of the total area of the Park $\left(150.000 \mathrm{~m}^{2}\right)$ and $170 \%$ larger than the area of the initial project. From 1945 to 1995, the arboreal increment was of $36.655 \mathrm{~m}^{2}$, practically doubling the total area of arboreal covering.

On 1945 and 1995, the masses grew, in area, pratically in the same proportion, and were adjusted to a straight line. 
One of the important characteristics of the English Landscape Style, rely on points that can be see through lawn the area, forming "lines of view"- leading to uninterrupted view of the opposite side across the lower strata (lawn). The value points of interest, such as constructions, exotic trees and others. In the original project of the ESALQ`s Park, ten lines of view were planned. In 1995, six of those lines were obstructed by the untamed growth of the masses and also for the construction of a building in area of the Park. Four of them can be cleared through simple management practices. Unfortunately the others, are no longer of liable for desobstruction due to the presence of the referred building.

The study of the floristic surveys of the arboreal/shrubby masses (masses number 1 to 22), carried out in the Park in the years of 1965 and 1991, were typed in the software Access. The floristic survey of 1965 shows that the Park was formed by 444 arboreal/shrubby individuals, which increased to 2.904 in the floristic survey on 1991. In the 1965, survey were found 241 arboreal/shrubby decreasing 215 species in 1991, with an increased dominance of some species on others (in numbers) as well as aggregate groups. The extinction of 154 arboreal/shrubs species and the increment of 124 was observed. Only 90 species were common to both surveys (1965 and 1991).

The presented facts, indicate the need of an urgent management of the masses of the ESALQ’s Park, to avoid farther uncharacterization. 


\section{INTRODUÇÃO}

O Parque da Escola Superior de Agricultura “Luiz de Queiroz”, é o único parque no Estilo Inglês de Paisagismo existente no Brasil, cujas características, foram parcialmente preservadas. Criado ao redor de 1907, compreende aproximadamente 15 ha, sendo, na cidade de Piracicaba - SP, onde está instalado, o segundo maior em dimensões e o mais freqüentado dentre os cinco parques existentes, que são: Parque do Zoológico (com 4,8 ha), Parque da Zona Leste (3,26 ha), Parque da Rua do Porto (25,2 ha) e o Parque do Mirante (com 1,64 ha). Estes citados parques, pertencem ao Estilo Misto de Paisagismo, que dá liberdade total ao paisagista, de misturar vários estilos. O Parque da ESALQ, é classificado, segundo Montenegro (1983), como sendo parque de preservação e setorial, pois, tem a finalidade de conservar valores naturais que mereçam ser perpetuados e estudados além de ser grande área destinada a recreação de toda a população municipal e regional, que o utiliza principalmente nos finais de semana e nas férias.

Formado por uma gama de espécies vegetais, nativas e exóticas, é muito utilizado pelos cursos ministrados na referida Escola, para estudos, pesquisas e atividades didáticas, sendo de grande valor histórico e científico. Contribui na amenização do microclima regional e é incluído no cálculo do índice de área verde da cidade de Piracicaba - SP (3,6 m²/hab.), sendo representado apenas por parte de sua área

total (apenas $50.000 \mathrm{~m}^{2}$ ), por estar sob a égide do Estado e, não à Prefeitura Municipal de Piracicaba. O Parque da ESALQ, com os $50.000 \mathrm{~m}^{2}$, representa 5,15\% do total da área verde utilizada no cálculo do índice de áreas verdes de Piracicaba.

O Parque é formado por canteiros de tamanhos e formas variadas, separados por ruas e compostos por cinco gramados e vinte e quatro maciços arbóreo/arbustivos, 
algumas construções, além de um canteiro que circunda o prédio da administração (Prédio Central), conforme ilustrado na Figura 22, na página 49. Ao longo dos tempos, os referidos maciços cresceram desordenadamente e demasiadamente, do ponto de vista de projeto paisagístico, vindo a modificar algumas das importantes características do Estilo Inglês de Paisagismo, propostas pelo arquiteto paisagista, idealizador do projeto do Parque, o belga Arsenio Puttemans. Do ponto de vista silvicultural, nota-se um grande domínio, em número, de algumas espécies vegetais sobre outras, dentro dos maciços arbóreo/arbustivos.

O presente trabalho tem como objetivos, estudar no decorrer dos anos, as transformações dos traçados ocorridos nos maciços vegetais projetados, utilizando-se de recursos computacionais e fotografias aéreas, bem como confrontar levantamentos florísticos dos maciços do Parque, elaborados em épocas diferentes. 


\section{REVISÃO DE LITERATURA}

Realizou-se a revisão de literatura abordando aspectos utilizados no estudo em questão, com o propósito de se obterem subsídios necessários para fundamentá-los.

\subsection{Estilo de Jardim Inglês}

O Estilo Inglês rompe a retidão e simetria das linhas e distribuição dos maciços arbóreo/arbustivos, característica dos outros estilos da época, promovendo uma nítida aproximação com a natureza. Predominado pelas linhas curvas das alamedas, conduz à observação tanto de pontos de destaque, através de espaços deixados entre maciços, quanto de impedir totalmente a vista do observador, através da implantação de maciços arbóreo/arbustivos em locais estratégicos, causando a impressão, de se estar caminhando dentro de uma mata fechada (Lima, 1987). Esses pontos de destaque, geralmente ficam a longas distâncias do ponto onde se encontra o observador, chegando às vezes estarem do lado contrário, próximos aos limites do Parque. Devido a esses fatos, o projetista pode criar linhas de visadas imaginárias e distribuir os maciços arbóreo/arbustivos pelo parque, de modo a não impedirem a visualização dos alvos a serem destacados.

Nos parques de Estilo Inglês, estão presentes grandes gramados, com amplos caminhos e se valoriza a topografia do terreno. Plantas floríferas compõem grandes manchas coloridas sobre o verde, onde árvores aparecem em pequenos grupos (AFLOTECC, 1990). ${ }^{1}$

\footnotetext{
${ }^{1}$ AFLOTECC - Assessoria Técnica e Consultoria S/C Ltda. Apostila de Curso - São Paulo, 1990. Não publicada
} 
Segundo Montenegro (1983), a mais antiga menção de ajardinamento, vem da China, onde o homem agrupou plantas tentando imitar a natureza e este foi o embrião do Estilo Paisagístico (Inglês). Pouco depois da China, surgiu na Pérsia e Egito, a semente de outra tendência de jardim - o geométrico ou regulares.

Segundo Santos (1975), essas duas tendências se difundiram pelos povos antigos, sendo alguns deles transpassando fronteiras. O Estilo Naturalista da China passou ao Japão no século VI, sofrendo modificações, se adaptando à cultura e filosofia do povo. Este Estilo só se tornou conhecido na Inglaterra no século XVIII, através de constantes viagem dos europeus à China, que puseram em moda o gosto pelas coisas vindas de lá. Em 1756, Chambers na volta de uma de suas viagens à China, foi quem introduziu definitivamente a idéia de colocar características chinesas nos jardins ingleses através de desenhos dos jardins do Príncipe de Gales em Kew, segundo os preceitos daquele país. No ano seguinte, publicou um volume em que desenha edifícios, móveis, trajes e utensílios chineses, onde dedica um capítulo a arte de compor os jardins segundo o uso dos chineses, explicando como são feitos. Posteriormente, conduzido pelas mãos hábeis de Kent, o jardim inglês adquiriu características próprias. Mercadal (1949), já coloca em dúvida a origem desse novo Estilo, dizendo que alguns autores atribuem a Charles-René Dufresny, neto do jardineiro Anet.

Santos (1975), relata que antes do Estilo Inglês se firmar na própria Inglaterra, a resistência dos ingleses à influências estranhas e continentais, mantinha o seu estilo fiel a tradição medieval. Apesar de que, com o tempo, as idéias do Renascimento foram abrindo caminho, lentamente, no país. Na primeira metade do século XVII, foi criado, na Inglaterra, um parque ítalo-francês, que mais tarde sofreu a influência do Estilo de Palladio. Nesses tempos os jardins regulares foram enriquecidos na Inglaterra por uma forma original de canteiro, adaptado na França. A Inglaterra, sofreu influência do humanismo, através da topiaria feita na Holanda, quando Guillerme III da Holanda ocupou o trono da Inglaterra em 1689, pondo fim a velha tradição. Porém, alguns autores ingleses ridicularizaram o exagero da arte de topiaria, atacando violentamente os jardins clássicos e estes foram se modificando, perdendo algumas de suas características, aumentando os terrenos planos, marcando as grandes linhas e dividindo os espaços 
intermediários e retirando os obstáculos visuais, fazendo desaparecer os muros de cimento e as árvores esculturadas.

Montenegro (1983), relata que enquanto isso o estilo de jardins regulares, se dividiram em dois ramos. Os jardins Egípcios, que ficavam nas margens do rio Nilo, com grandes planos horizontais orientados pelos pontos cardeais pois, na época, a astrologia era a crença que dominava e o outro ramo foi o dos jardins Persas, onde os mais famosos do Estilo foram os Jardins Suspensos da Babilônia.

Em meados do século XVII, o Estilo Egípcio foi introduzido na França e em Roma. Neste último, foi modificado, dando surgimento ao Estilo Italiano (Jardim da Renacença). Porém, com a introdução de arquitetos italianos na corte da França, as idéias do Estilo Italiano foram ganhando espaço. Surgiu então a Escola de Jardim do Renascimento Francês, que serviu de base ao grande arquiteto e jardinista de Luis XIV, André Le Nôtre, para criar uma série de jardins e parques. Surgia aí o Estilo Francês de jardinagem, onde o Parque de Versalhes (criado por Le Nôtre), é o maior exemplo do Estilo.

Ainda Santos (1975), assevera que um determinado estilo, quando alcança o seu máximo de perfeição, entra na fase em que, a repetição das formas consagradas, se torna cansativa e consequentemente, o desinteresse e quase sempre o abandono. Além de que, nem todo imitador tem a mesma habilidade artística de Le Nôtre, descaracterizando as obras. Foi por isso que no século seguinte, o Estilo Francês caiu, a começar do próprio Luis XIV já envelhecido e cansado do estilo do parque de Versalhes. Aí Marly Leroi, passou a construir um refúgio para o grande monarca. Com a morte de Luis XIV, os artistas passaram a criar outros jardins em outros estilos completamente diferentes do Francês. Iniciava a era do Estilo Luis $\mathrm{XV}$, que se modificou buscando maior aproximação com a natureza. Este novo Estilo não foi criado na França e sim nas Ilhas Britânicas, que, como já comentado, se inspiraram nos jardins chineses do Velho Império. O Estilo Inglês, que se espalhou por parte da Europa, inclusive para a França, onde no século XVIII, estava a ponto de se destruir o parque de Versalhes. Este Estilo ficou em evidência durante dois séculos, tornando-se em seguida complicado no traçado, com exageros na decoração e deu lugar ao Estilo Misto de jardinagem. Este Estilo, 
conforme já comentado, não é preso a nenhuma regra básica, dando ao jardinista a liberdade de criação.

As características do Estilo Inglês de Paisagismo, segundo alguns autores, estão relatados abaixo:

Montenegro (1983), cita que o Estilo é marcado por extensos gramados, pequenos bosques, caminhos em curvas suaves e arbustos ou árvores isoladas.

Santos (1975), o Estilo Inglês é representado por linhas grandiosas; amplas extensões verdes (gramados); ruas amplas, cômodas e em pequeno número; terrenos acidentados e possibilitando a visão de belas perspectivas; pequenos bosques, compostos de plantas da mesma ou de espécies diferentes, com ou sem divergência nas colorações; grupos de árvores não muito numerosas; plantas isoladas; implantação de árvores mortas; construção de ruínas.

Mercadal (1949), cita alguns elementos usados no Estilo: flores; grandes plantas ornamentais; arbustos de todos os tamanhos; tanques (para colocação de plantas aquáticas, cujo maior exemplo são os jardins da Europa no final do século XVIII, com a introdução de vitória régia trazida do Brasil e América equatoriana); riachos; rochas; colinas artificiais; labirintos; quiosques e obras fabricadas.

Bellair \& Bellair (1939), dá um maior detalhamento dos aspectos arquitetônicos utilizados no Estilo, onde:

- as alamedas: as principais são largas e côncavas para facilitar o escoamento da água das chuvas e podem ser carroçáveis ou não, dependendo da importância do parque (Figura 1). Geralmente a alameda que contorna o gramado principal do parque, que geralmente fica defronte ao prédio, é carroçável e larga, já as alamedas secundárias, são estreitas e planas e geralmente não carroçável. Estas características, podem ser vistas na Figura 2. As alamedas, não devem ser pavimentadas, para auxiliar na infiltração da água (Figura 3). 


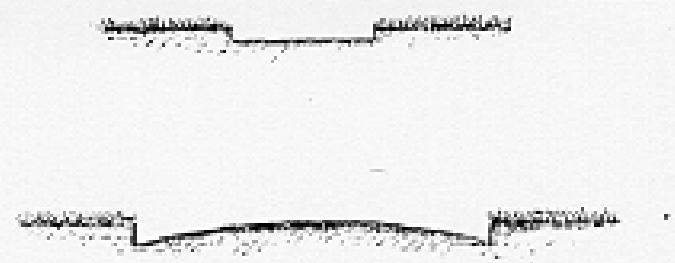

Figura 1. Desenho mostrando as alamedas: larga (côncava) e a estreita (plana). Fonte: Bellair \& Bellair (1939).

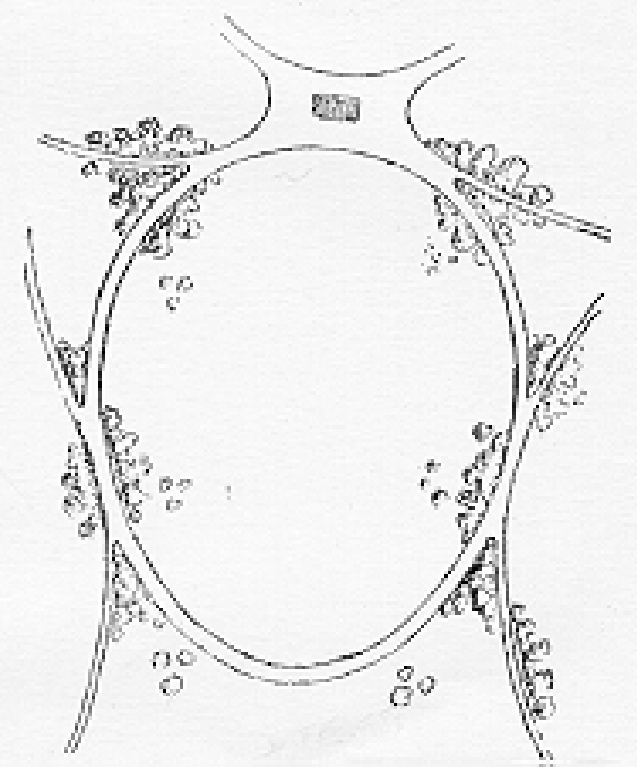

Figura 2. Projeto paisagístico no Estilo Inglês, mostrando as alamedas principais mais largas e as secundárias, mais estreitas. Fonte: Bellair \& Bellair (1939). 


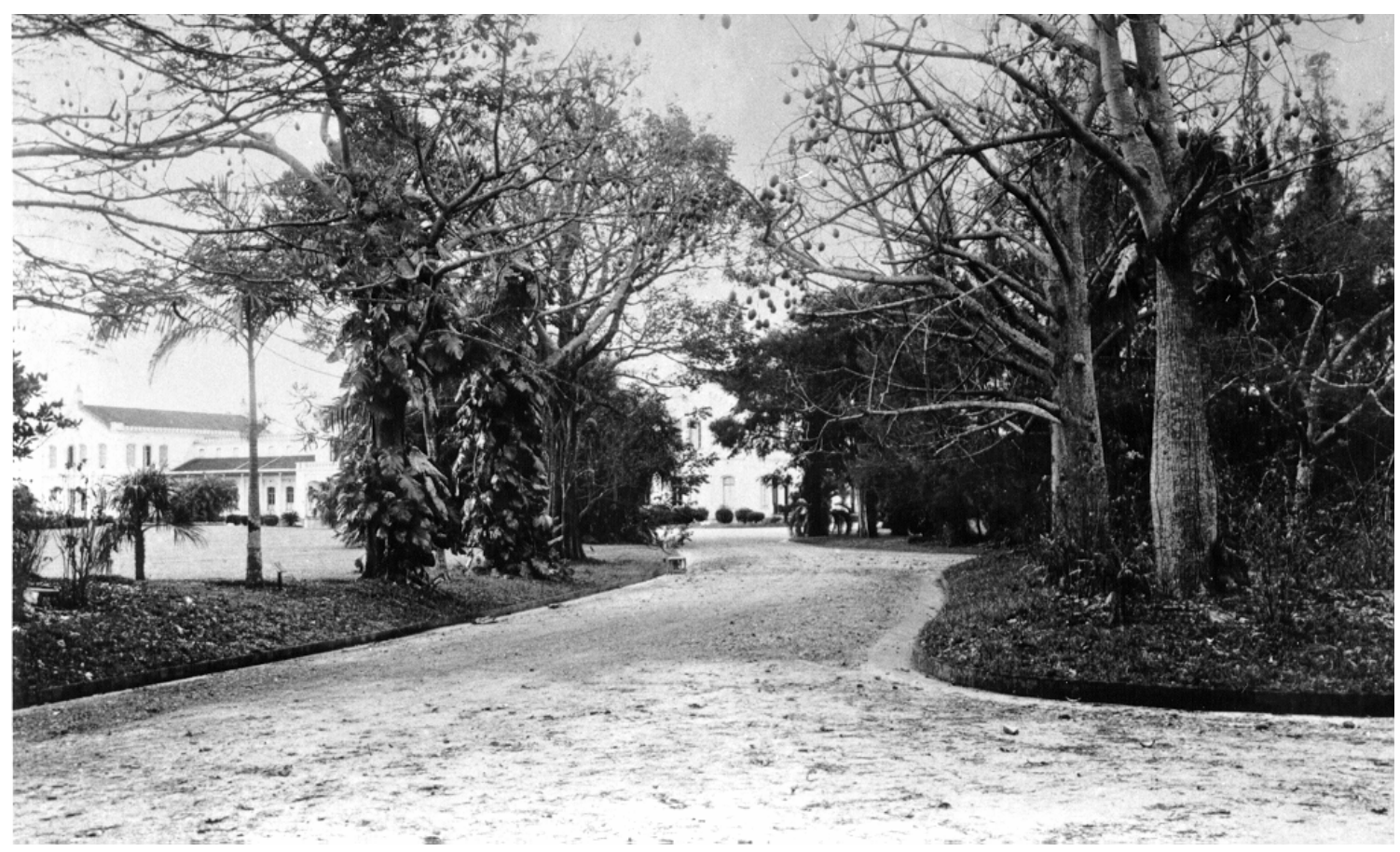

Figura 3. Fotografia do Parque da ESALQ, tirada na década de 50, ilustrando uma alameda desprovida de pavimento.

- as bifurcações - quando as alamedas que formam a bifurcação, são da mesma importância (as duas alamedas são primárias ou secundárias), deve-se causar no observador, indiferença, abrindo a bifurcação das alamedas, exatamente na bissetriz da alameda que as formará (Figura 4). Quando de importâncias diferentes, deve-se direcionar a alameda secundária, para o lado contrário da curva e a primária, continuar na curvatura que já estava (Figura 5) ou, esta tendo menor largura, conduz o visitante do parque, cessando a indecisão sobre a direção a tomar (Figura 6). As bifurcações devem ser cercadas de maciços, para que as alamedas sejam bem visíveis e a bifurcação seja notada pelo observador. 


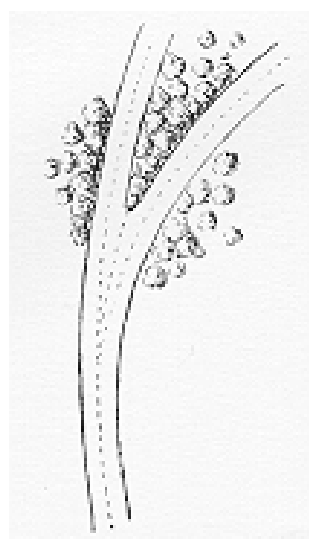

Figura 4. Desenho mostrando como deve ser a bifurcação de duas alamedas de mesma importância. Fonte: Bellair \& Bellair (1939).

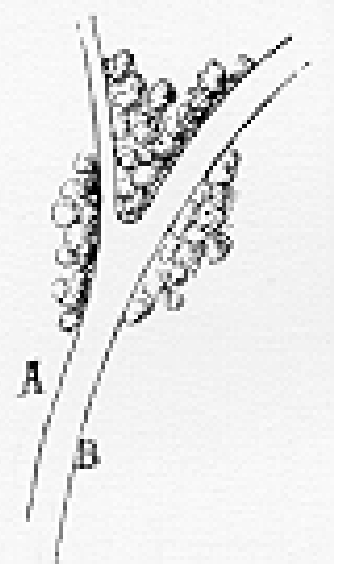

Figura 5. Desenho mostrando como deve ser a bifurcação entre uma alameda principal e uma secundária. A guia A é da alameda côncava e a guia B, da convexa. Fonte: Bellair \& Bellair (1939).

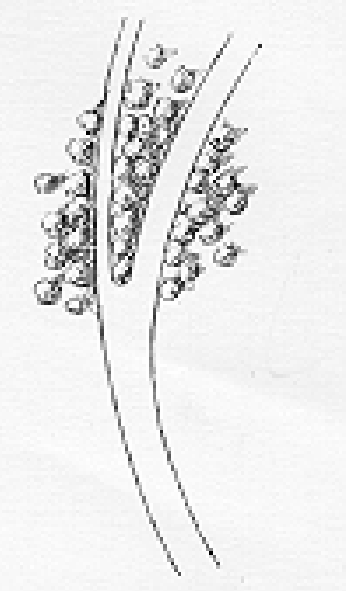

Figura 6. Desenho mostrando como deve ser a bifurcação entre uma alameda principal e uma secundária. Fonte: Bellair \& Bellair (1939). 
- a entrada do parque: é formado por uma alameda reta, com árvores plantadas ao longo da mesma, alinhadas e em grupos simétricos (Figura 7). Para se chegar na edificação (prédio principal), tem-se sempre dois caminhos. Nunca a entrada fica defronte à edificação, mas se não houver outra alternativa, deve-se por motivo de segurança, implantar um maciço arbóreo na frente do portão de entrada, para que o observador que passa defronte ao parque, não tenha visão para o seu interior do parque e ainda, deve-se deixar à vista, as laterais desse maciço, para que, a segurança da edificação em destaque que está sendo valorizado, tenha controle de quem adentra o recinto (Figura 8).

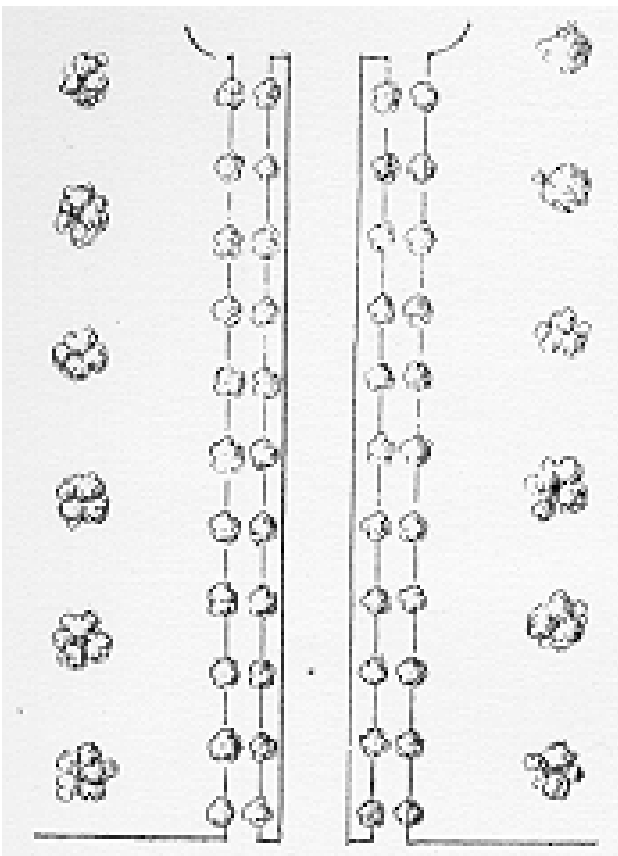

Figura 7. Desenho mostrando a entrada de um parque ladeada por maciços arbóreos. Fonte: Bellair \& Bellair (1939). 


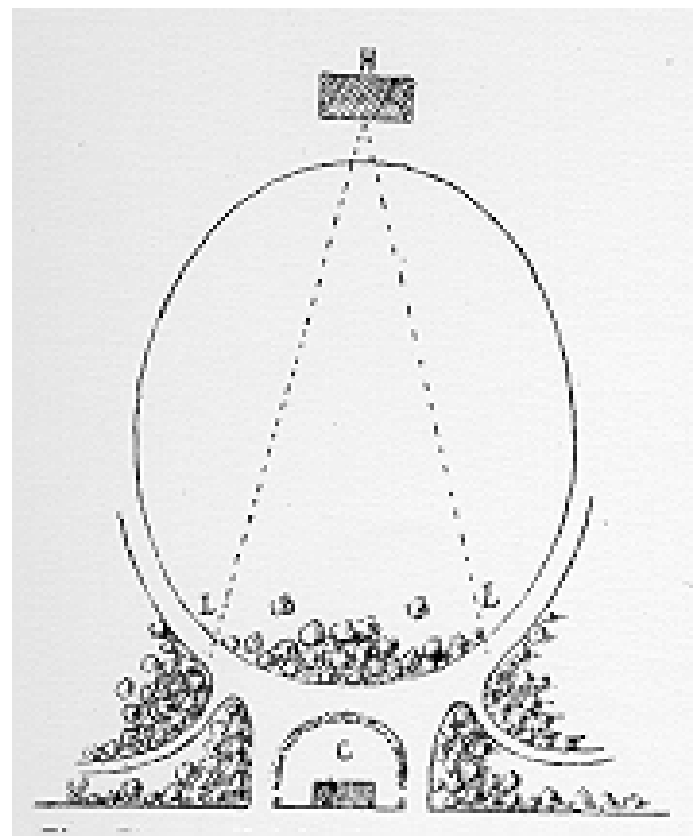

Figura 8. Desenho mostrando o ângulo de visão que a segurança do parque deve ter para controlar a entrada de pessoas. Onde: H, é a edificação; C, é um gramado e L, é o local de visão da segurança. Fonte: Bellair \& Bellair (1939).

- os gramados: apresentam quatro característica importantes:

- extensão - não depende somente das proporções do parque, mas também dos outros elementos (maciços, rochas, ruas, bosques...). É importante reservar uma superfície grande para traçar as visadas e principalmente a visada principal que é a que parte da edificação. Os gramados devem ser longos e largos para dar aspecto de calma e conforto.

- forma - têm estreita relação com a direção das alamedas. São as alamedas que determinam os contornos dos gramados. Geralmente o gramado da frente do prédio têm formato oval, elíptico ou triangulares curvilíneos, nunca trapezoidais.

- relevo - a extensão e contorno do gramado, indicam a maneira com que o terreno decliva ou acliva, e ainda com a presença de pedras ou não. Portanto são dois elementos os que causam desnível desejado: rochas e pequenos vales. As saliências devem ficar fora da linha das visadas para não encobri-las ou então, se adaptarem a elas. - ondulações - apresentam 4 fatores:

- não diferenciar exageradamente do relevo natural do solo; 
- rebaixar o meio do gramado formando rampas convergentes (Figura 9);

- plantar árvores e arbustos longe dos fundos dos vales, perto dos locais onde foi colocado solo para formar elevações;

- entre dois maciços, entre dois canteiros de flores, entre um canteiro e um maciço, estabelecer pequenos vales que alcancem o vale principal que é no gramado principal (Figura 9).

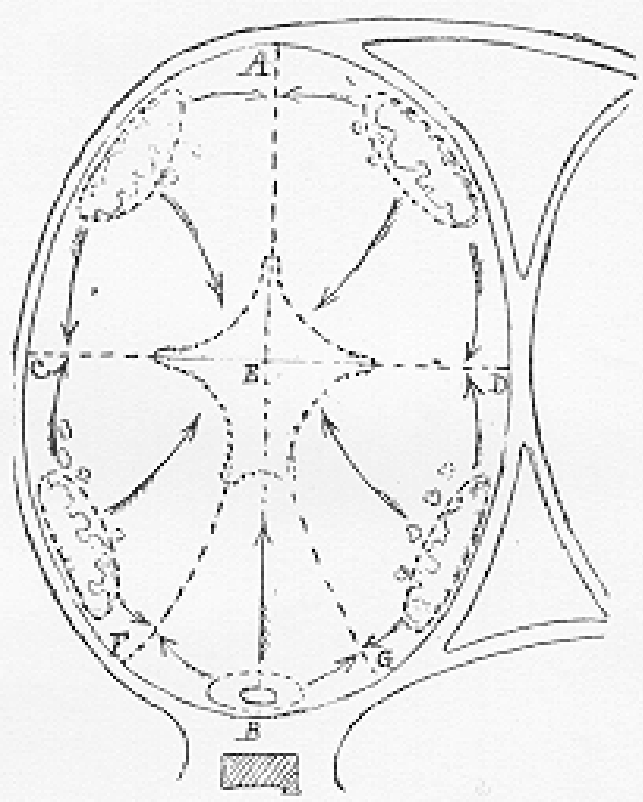

Figura 9. Desenho mostrando como deve ser o relevo do gramado principal, onde: as linhas AE, CD, FE e GE, delimitam os declives e E, é a cota mais baixa do vale. Fonte: Bellair \& Bellair (1939).

Os gramados devem dar a sensação ao visitante do parque de estar pisando em um tapete. Por isso, a espécie de grama deve ser escolhida de acordo com o solo, clima e condições de irrigação e drenagem, do local.

- os rochedos: constituem a segunda forma dos relevos do solo. Os rochedos são a ossatura do solo, que podem permanecer cobertas por uma fina camada de terra vegetal. Os relevos podem apresentar formas graciosas ou arredondadas constituindo relevos suaves, como podem apresentar relevos ásperos, geralmente descoberto de vegetação, ou coberto por musgos e plantas rasas. 
- classificação estética: se classificado por ordem de valor ou importância ornamental dos elementos constituintes de um jardim, a primeira parte a ser analisada será o gramado e as árvores, por último, os rochedos.

- impressões que os rochedos dão: em regiões montanhosas de solos rasos ou inexistentes, onde os rochedos aparecem descobertos de vegetação arbórea e/ou arbustiva, as rochas aparecem com toda sua beleza, que é impressionante e indiscutível. Mas é necessário lembrar, que o objeto de estudo é um jardim de impressões agradáveis, que oferecem a serenidade, a calma e a contemplação, pois as paisagens citadas acima causam insegurança, que não é o objetivo do Estilo em questão.

- a aprovação com certa precaução: como já dito, as rochas só devem aparecer nos jardins com certa reserva. Esses elementos não devem ser aceitos, por exemplo, sobre um terreno plano, pois seu lugar na natureza, é nos barrancos, ribanceiras ou nas grandes alturas, já que os rochedos são elementos de altitude, assim sendo, dentro das condições que eles encontram na natureza, eles podem ser usados por trabalhos de terraceamento e escavamento, pondo assim, os rochedos no relevo.

- regras impostas: com a concepção de jardins paisagísticos (ou ingleses), as regras a seguir serão impostas como de bom gosto para os locais onde serão introduzidos rochas com caráter paisagístico. Tirar a maioria dos rochedos que não têm afinidade com a origem natural do solo. Os rochedos só são aceitos quando são colocados nos declives, ou na base das subidas, ou melhor, quando eles formam um apoio de rochas, que sustentam a altura da paisagem.

Não utilizar nenhum tipo de rocha, natural ou artificial, que cause impressão de instabilidade e insegurança a quem caminha pelo jardim.

Dentro dessas condições, evitar rochas que dêem um ar de suspeitas no espaço, nem rochas enterradas, que logo quando se passe, transmita a idéia de um possível desabamento.

Dar preferência a rochedos que ofereçam disposição normal, em bancos horizontais ou oblíquos, aos rochedos em bancos verticais, sendo estes últimos mais raros na natureza. 
Admite-se ainda, dois tipos de disposição:

$1^{0}$ - em massas mais ou menos agregadas, com ressaltos, de forma áspera etc;

$2^{\circ}$ - em blocos separados, como se fosse proveniente de desmoronamentos naturais, enterrados no solo, a uma pequena distância da massa principal, de onde eles provêm.

- as árvores: são elementos essenciais na decoração de um jardim paisagista. Podem estar presentes no parque nas seguintes formas:

- florestas e bosques - no Estilo Francês, plantam-se as árvores agrupadas e bastante adensadas formando um bosque e as recorta simetricamente com caminhos. Em outros estilos, deixa se uma abertura no bosque para visualização da edificação. Nesse caso, para dar um ar mais pitoresco, é recomendável que se mexa nas cotas do terreno. Outra alternativa, é deixar a borda do maciço recortada, com árvores plantadas fora de alinhamento, próximas ao maciço adensado, para dar um ar mais pitoresco, ou manter um alinhamento de plantio segundo uma forma arredondada, para ficar mais tradicional (Figura 10).
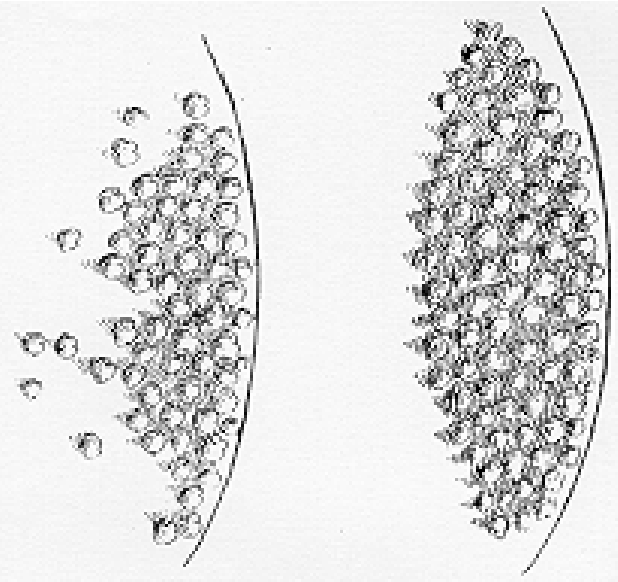

Figura 10. Desenho mostrando a borda do maciço recortada (desenho à esquerda) e arredondada (desenho à direita). Fonte: Bellair \& Bellair (1939).

- maciços - as árvores são ainda plantadas adensadas, se confundindo com a cobertura de grande superfície. São compostos por pequeno número de essências onde uma não domina as outras. No espaço reservado para os maciços, que estão em primeiro 
plano, são plantadas árvores de folhagem verde escuro e os afastados, de folhagem verde claro. Da mesma forma que nos bosques, as bordas dos maciços devem ser recortadas irregularmente, apresentando linhas arredondadas. Quando a borda do maciço é regular, é recomendável a implantação de canteiros floríferos no local.

- localização dos maciços - são indicados conforme a necessidade de se adaptarem ao local: necessidade de dar segurança impedindo a visada a certos pontos da propriedade, proteger o pomar e todos os pontos ao redor do jardim, a fim de mascarar as casas dos vizinhos, os muros e as cercas, necessidade de impedir a visão dos limites da propriedade, necessidade de desimpedir e desenquadrar os espaços que conduzem a pontos de visada; necessidade de obter sombra sobre os pontos vizinhos aos cruzamentos, quadras de tênis, salas de jogos ou de repouso para dar uma característica de intimidade. Os maciços devem ficar 0,6 m a 1,5 m de distância da borda do canteiro em relação à alameda.

- grupos de árvores - são grupos de poucas árvores que podem ficar praticamente contíguos ao maciço ou isolados deles. Os grupos podem ser formados por 3, 4, 5 ou 7 árvores/arbustos, que são dispostos regular (formando losangos, quadrados, triângulos) (Figura 11) ou irregularmente (totalmente disforme, sem obedecer um polígono regular) (Figura 12). Elementos (maciços, montículos, coretos, rochas) são implantados em alamedas curvas para ressaltar a curvatura.
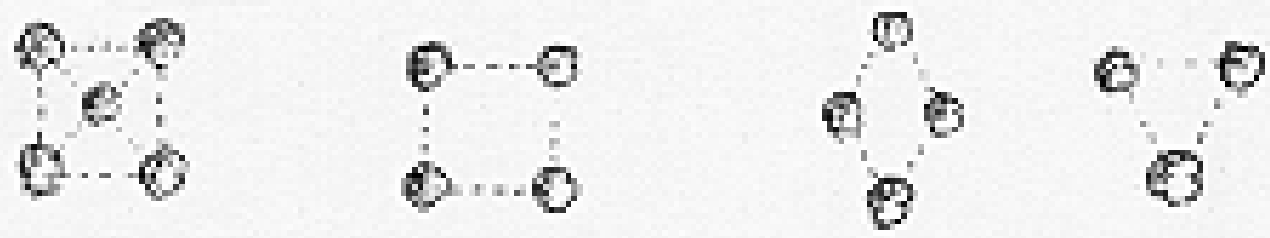

Figura 11. Desenhos mostrando as várias maneiras de distribuir regularmente as árvores. Fonte: Bellair \& Bellair (1939). 

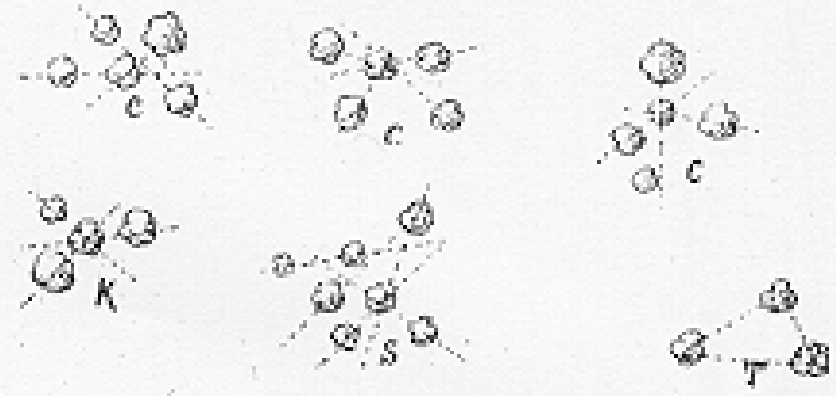

Figura 12. Desenhos mostrando as várias maneiras de distribuir irregularmente as árvores, onde: T, para 3 árvores; K, para 4; C, para 5 e S, para 7. Fonte: Bellair \& Bellair (1939).

- árvores isoladas - são geralmente árvores especiais, nativas ou exóticas, que possuam beleza extraordinária. São plantadas em pontos de visada especiais.

- as vistas: há uma estreita ligação entre as árvores e as vistas. Uma vista, é uma superfície enquadrada, onde, ao fundo existe um objeto (monumento, colina, um grupo de árvores formando um ponto de vista, uma árvore isolada etc). Assim, deve-se considerar três fatores: o ponto de vista, o espaço livre até onde o olho do observador está e o quadro.

- posição dos pontos de vista - os pontos de vista estão no interior do jardim ou fora dele. Nos pequenos jardins das cidades, não se deve ter as vistas fora deles, ou ainda, ter o cuidado de mascarar uma falsa impressão, se ela existir.

Já em um jardim extenso, situado no campo, querer traçar as vistas dentro dos limites da propriedades, é um erro. Deve-se, ao contrário, respeitar as áreas de fora, como as colinas, os rios, os bosques, os vilarejos, o mar etc, pois estes pontos de vista, longínquos, vão se distanciando, como o branco da manhã, o negro da noite e o multicolorido do meio dia, quando o sol, os banha de luz.

- criar paisagens e aumentar a extensão da linha de visada - é a busca dos pontos de vistas no exterior do jardim, criando paisagens e aumentando-se assim, as divisas do terreno onde o mesmo se instalará.

Assim que escolhida a paisagem para ser enquadrada, deve-se colocar nos primeiros planos, árvores altas e para os planos sucessivos, árvores cada vez mais com 
menor altura. Assim para a linha de vista, aparecerá um grande vasto, onde a mesma caminhará (Figura 13). Este engenhoso procedimento poderá ser inútil, se for escolhido o ponto de vista, perto do limite do jardim, deixando-se uma paisagem natural de fora, como por exemplo: um barranco arborizado, uma ilha etc.

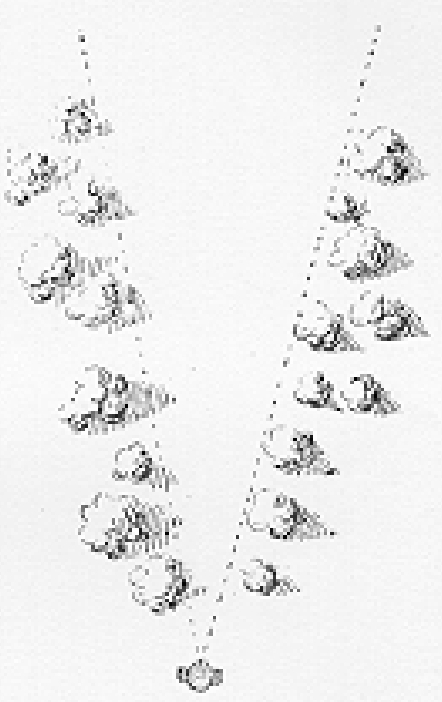

Figura 13. Desenho mostrando como se deve dispor as árvores, para direcionar as linhas de vista. Fonte: Bellair \& Bellair (1939).

- centrar e determinar os pontos de vista - como em uma pintura, deve-se buscar, na criação, vistas bem centralizadas, bem determinadas, a fim de evitar o cansaço do olho, que se perde sobre espaços muito extensos, com ausência de relevos e quadros.

Com o objeto essencial para formar uma determinada paisagem (pontes, rios, árvores, coreto etc), o principal cuidado é de agrupar no primeiro plano, aos dois lados do ponto de vista, grupos de árvores que forçam o olho a observar sempre em frente. Um pouco mais longe, sucessivamente, sempre dos dois lados da linha de vista, outros grupos de árvores que indicam a direção do ponto do observador, centrados na paisagem.

- centro de partida das vistas - os pontos de partida de linhas de vistas, são razoavelmente numerosos e importantes, onde um deles, geralmente o da edificação, é o principal e domina os outros pontos. 
No jardim, a edificação não é somente o centro de partida, mas um centro de convergência das vistas, onde devem passar a maioria das linhas de vistas. Tem-se todos os lados da edificação para ser explorado, porém, devem ser enquadrados com a implantações de árvores, ao seu redor, emoldurando-a.

Comparando com a edificação, os outros centros de partida das vistas são secundários e são indicados para relevos naturais do solo e marcados por um estabelecimento, edícula, coreto, banco, maciço arbóreo etc.

- as flores: são interessantes peças do Estilo Naturalista (Inglês). Se as árvores são interessantes pelas suas formas, as flores seduzem pela sua coloração. Mas são consideradas de segunda grandeza, pois, mesmo se optando por espécies mais rústicas, requerem manutenção, que, muitas vezes, é indesejável.

Devem ser usadas, formando-se canteiros, em lugares estratégicos, como por exemplo: na frente da edificação (figura 14), na frente dos maciços arbóreos, em pontos de vista etc, enfatizando o local.

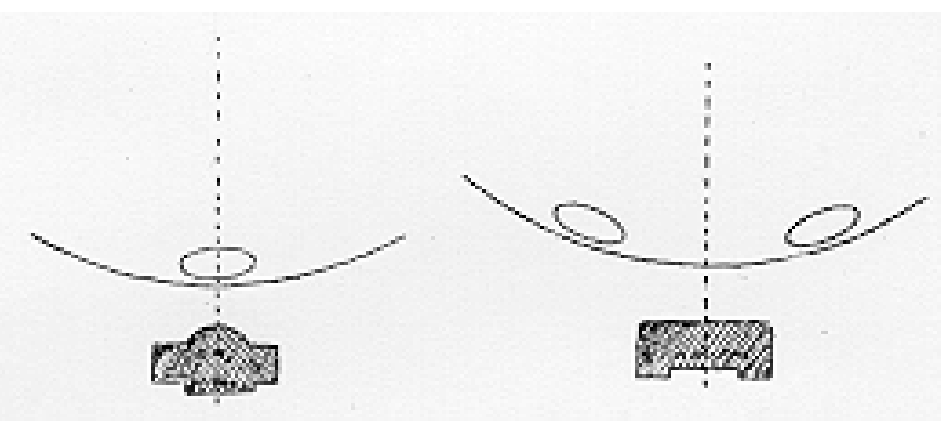

Figura 14. Desenho mostrando como se deve distribuir o canteiro de flores na frente da edificação. Fonte: Bellair \& Bellair (1939).

- as águas: em um local pouco acidentado, é possível criar um jardim com os objetos normais (árvores, arbustos, gramados, flores etc) e mais de 50\% dos jardins não comportam outros objetos. Quando o relevo é acentuado, com barrancos e concavidades, pode-se optar por outros elementos: como a água e as rochas.

$\mathrm{Na}$ natureza, as águas ficam dormente, caem, correm, brotam etc e, sendo o Estilo Paisagístico Inglês) de jardim, uma imitação da natureza, deve-se, ao máximo, 
tentar deixar o rio, lago, corredeira, etc, com aspecto natural, modificando-se o relevo onde o mesmo vai ser implantado.

As águas dormentes (lagos), dão a impressão de descanso, as correntes (cascatas), dão impressão de agitação, de movimento. No geral, as águas paradas devem ser usadas em grandes espaços, como em parques públicos, por exemplo e as águas correntes, em pequenas propriedades privadas.

O parque precisa ainda, de área destinada à construção de estufas e casas de vegetação, para produção de floríferas vivazes e anuais para reposição nos canteiros, a fim de manter, tanto o embelezamento do parque propriamente dito, quanto da edificação.

Dois exemplos de planta baixa de parques executado no Estilo Inglês de Paisagismo, dentre eles, um realizado por Arsenio Puttemans e outro de local desconhecido, podem ser vistos nas figuras abaixo (Figuras 15, e 16). 


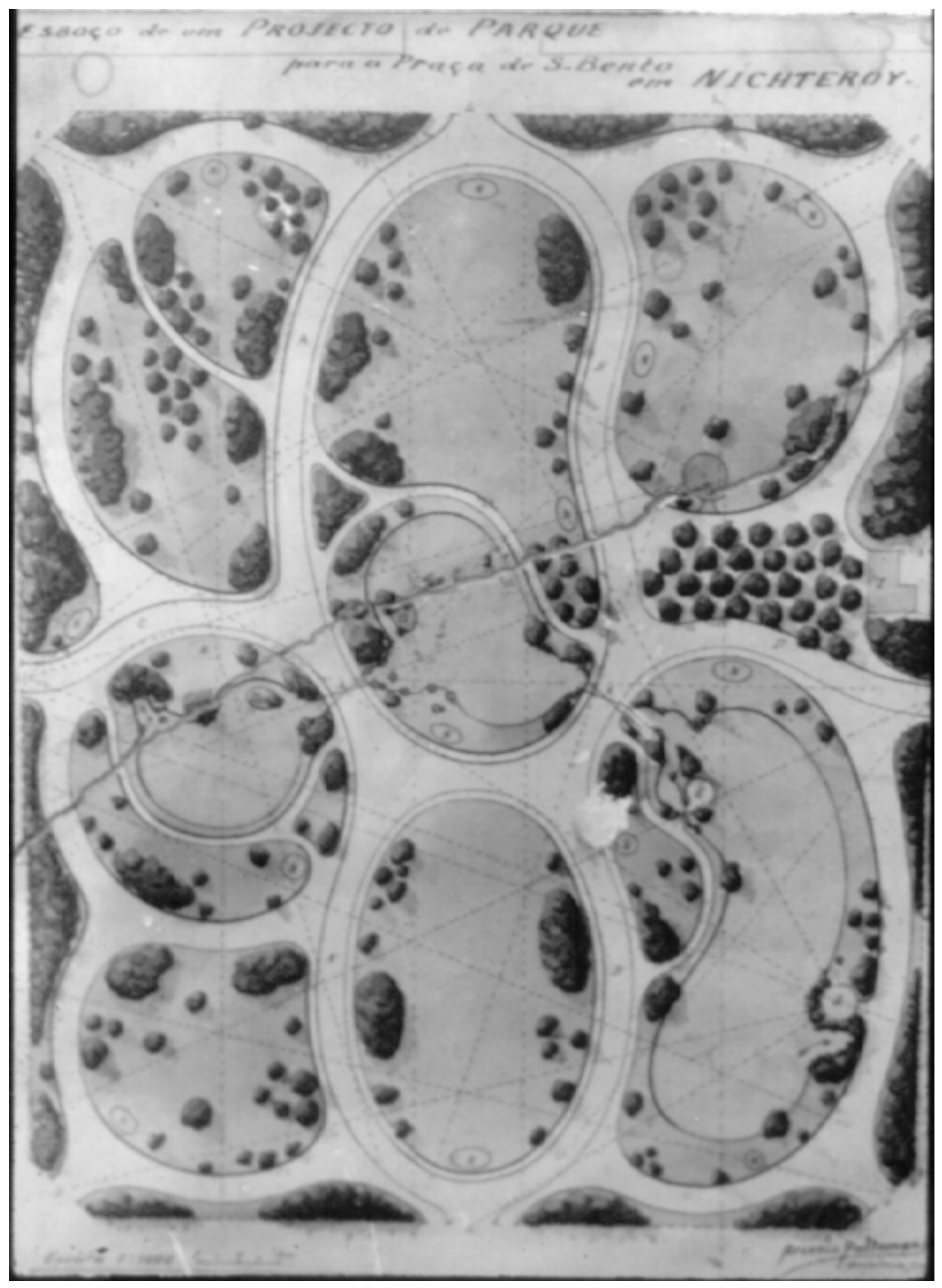

Figura 15. Projeto Paisagístico de Parque para a Praça de São Bento em Niterói-RJ, elaborado por Arsenio Puttemans. 


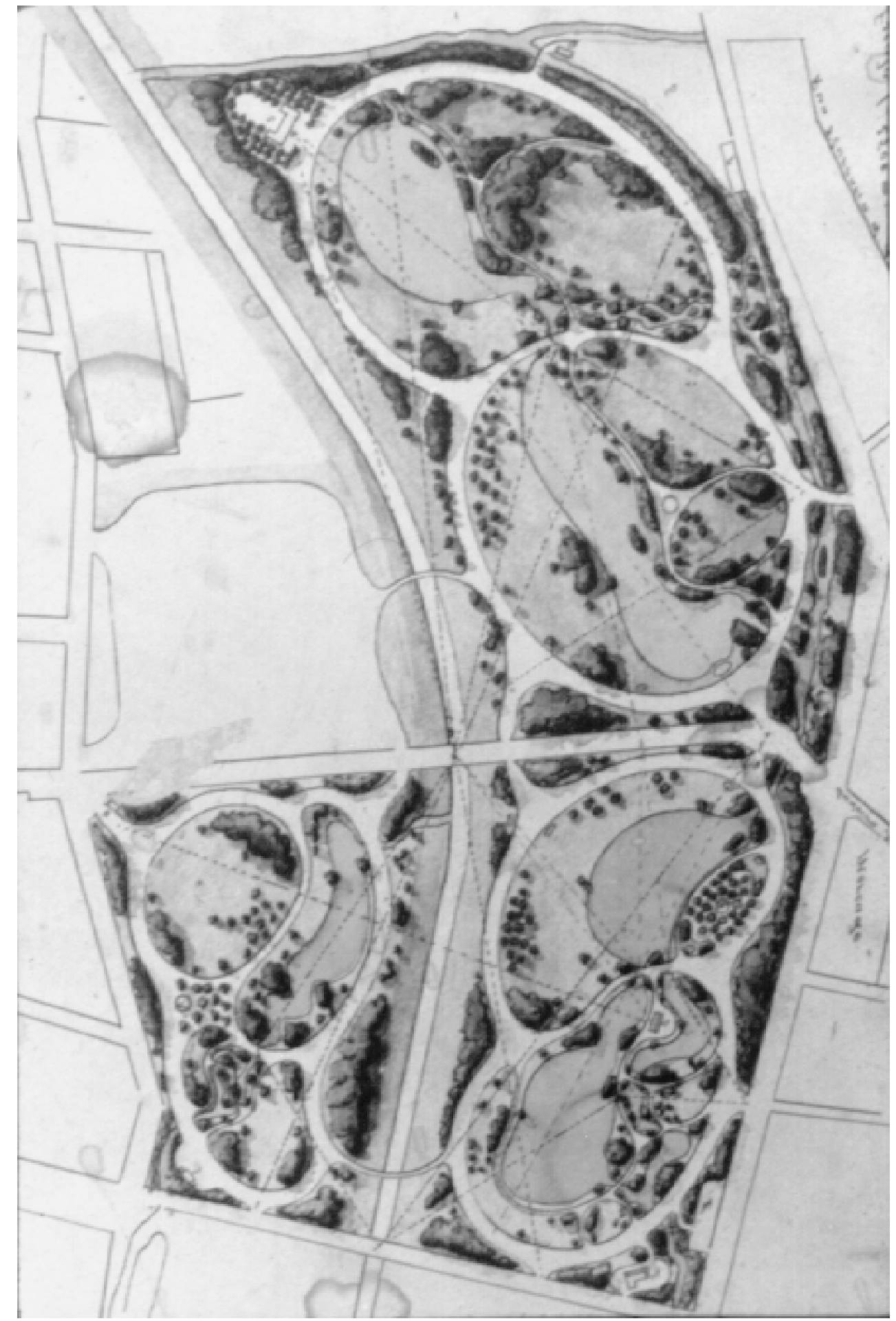

Figura 16. Projeto Paisagístico de um parque no Estilo Inglês de Paisagismo. 


\subsection{Importância de Áreas Verdes}

Segundo Jorgensen (1974), a Silvicultura Urbana tem como objetivo, o cultivo e manejo de árvores e florestas, visando contribuir para o bem estar psicológico, sociológico e econômico da sociedade urbana, que pode ser alcançado através da criação de áreas com as seguintes características:

- recreação e lazer, inclusive com habitats para a vida silvestre;

- educação ao ar livre;

- reciclagem de resíduos urbanos;

- produção de árvores para uso diversificado, principalmente paisagístico;

Quanto às árvores isoladas, as técnicas de cultivo empregadas, são extensivas, semelhantes às da jardinagem, onde o cuidado contínuo é necessário. A Silvicultura Urbana procura sistemas de suporte ecológico natural para o crescimento das árvores, onde a manutenção e cuidados sejam mínimos. É uma abordagem mais ambiental no sentido de minimizar a necessidade de interferência humana sobre as árvores produzindo ambientes mais silvestres, onde o nível de manutenção e, consequentemente, de investimento são menores (Jorgensen, 1974).

As áreas verdes influem no clima de uma cidade, pois, os vegetais de uma forma geral, interceptam, refletem, absorvem e transmitem radiação solar, diminuindo a temperatura do ar no ambiente urbano (Grey \& Deneke, 1978). Normalmente a amplitude térmica da cidade é maior que a de áreas arborizadas, seja ela parque, área rural, praça etc.

Podem ainda funcionar como filtros naturais de poeira e som e ainda, melhoram a qualidade do solo, da água e da fauna (Couto, 1994).

Couto, Sao, Hirakawa et al. (1998) ${ }^{2}$, caracterizam espaços verdes livres como espaço público ou privado que oferecem ao usuário, com segurança, ótimas condições, para práticas de esportes, passeios, descanso e contemplação, onde a vegetação é elemento fundamental.

${ }^{2}$ COUTO, H.T.Z.; SAO, K.Y.; HIRAKAWA, C. et al. Projeto de manutenção dos indivíduos do Parque da ESALQ. Piracicaba - SP. 1998. (Não Publicado). 
O mesmo autor, comenta ainda a influência desses espaços na redução da poluição atmosférica e sonora, na temperatura, umidade e vento; absorção de raios solares e de poeiras e sólidos em suspensão, no estado psicológico, através de cores, sons e relações sociais, incluindo a recreação e descanso e na estética da região através das relações de proporções e volumes.

\subsubsection{Classificação de áreas verdes}

Montenegro (1983), caracteriza parque como área verde destinada a recreação e lazer e as classifica de acordo com o valor e situação, em:

- parques nacionais;

- parques estaduais;

- parques municipais;

- parques intermunicipais;

- parques metropolitanos.

Onde os dois primeiros são formados por grandes áreas, geralmente de algum interesse de preservação (reservas florestais, biológicas, sítios arqueológicos etc) e os outros três, os parques urbanos, ficam mais próximos da população e são classificados em:

- parque de preservação - aqueles que têm por finalidade conservar valores naturais ou culturais que mereçam ser perpetuados;

- parques especiais - criados com finalidade específica (jardim botânico, jardim zoológico etc);

- parque de recreação - áreas verdes equipadas para atender a recreação de toda a população urbana;

- parque de vizinhança - pequena área para atendimento à recreação infantil (play-ground);

- parques de bairro - área média para atendimento de jovens e área de estar de adultos; 
- parque setorial (ou metropolitano) - grandes áreas equipadas para a recreação de toda a população municipal ou metropolitana que as usa nos finais de semana ou férias.

O autor cita ainda, alguns critérios de localização para parques:

- fundos de vales;

- áreas com alta declividade;

- bacias hidrográficas;

- margens de cursos d`água;

- beira de represas;

- áreas de interesse natural, histórico ou cultural;

- alto de morros.

O Parque da ESALQ, segundo a classificação de Montenegro (1983), está dentre os parques urbanos, mais precisamente parque para preservação e ainda parque setorial, pois, tem finalidade de conservar valores naturais que mereçam ser perpetuados, além de ser grande área destinada a recreação de toda a população municipal e regional, que o utiliza principalmente nos finais de semana, feriados e períodos de férias escolares.

Já Salvador (1978), classifica áreas verdes como:

1. Áreas de recreação - destinado a receber equipamentos específicos para recreação da população residente. Podem ser:

1.1 - parque de vizinhança - destinado a recreação ativa das crianças de 0 a 9 anos e passiva das demais faixas etárias, com raio máximo de atendimento de $500 \mathrm{~m}$;

1.2 - parque de bairro - destinado a recreação ativa de crianças de 10 a 14 anos e passiva para as demais faixas etárias, com raio máximo de atendimento de $1000 \mathrm{~m}$;

1.3 - parque distrital - destinado a recreação ativa e passiva de todas as faixas. É mais frequentado nos finais de semana, utilizando-se os espaços potenciais disponíveis. A área de influência abrange vários setores de recreação, atingindo raio máximo de 5000 $\mathrm{m}^{2}$;

1.4 - parque metropolitano - áreas de grandes dimensões, a serem dotadas com equipamentos destinados à população metropolitana em geral. 
2. Área de preservação de recursos naturais - dotadas de características que recomendam sua preservação por razões de dimensão, qualidade e importância (biológica, social, cultural, ambiental ou paisagística), que apresentam tipicidade capaz de singularizar ou particularizar um sítio natural. São os seguintes tipos de áreas de preservação estabelecidos:

2.1 - área de proteção ambiental - destinadas a preservação de rios, lagoas, diques, represas, campos de dunas, massas vegetais e outros elementos naturais, independentes de outra utilização econômica ou social;

2.2 - área de proteção de mananciais - preservar cursos d’água e represas para abastecimento de água da população, seja efetiva ou potencial;

2.3 - área de proteção de encostas - preservar áreas com alta declividade, inadequadas para a urbanização;

2.4 - área de proteção paisagística - preserva lugares, sítios e acidentes geográficos que apresentem importância visual ou sejam dotadas de elementos naturais raros ou comuns que justifiquem proteção.

3. espaços abertos - resultante da urbanização executada por agentes públicos ou privados e em decorrência disto, destinados a uso coletivo. Incluem entre estes: jardins, praças, mirantes, áreas de circulação e parques de estacionamento.

Bianchi ${ }^{3}$, citado por Demattê (1997), insere ainda dentro desta classificação de áreas verdes, o verde de acompanhamento viário, que são áreas sem caráter conservacionista ou recreacional, tendo apenas função ornamental, mas podendo interagir no ambiente urbano. Como exemplos citam-se as rotatórias e canteiros de avenidas.

O Parque da ESALQ, na classificação proposta pela Prefeitura Municipal de Salvador, se enquadra tanto como área de recreação, como de proteção. É área da recreação, por apresentar características de parque distrital pois, proporciona atividades de lazer ativo e passivo, para todas as faixas etárias, possuindo grandes espaços

3 BIANCHI, C. G. Caracterização e análise das áreas verdes urbanas de Jaboticabal-SP. 1989. 62p. Trabalho (Graduação em Agronomia) - Faculdade de Ciências Agrárias e Veterinárias - Universidade Estadual Paulista. 
potenciais para recreação. Como área de preservação, apresenta características de proteção ambiental tais como, as inúmeras espécies vegetais nativas e exóticas, presentes em seus maciços, de grande importância biológica e do projeto paisagístico quase centenário e único no Estilo Inglês de Paisagismo, tendo grande importância histórica e paisagística.

A Secretaria Municipal de Defesa do Meio Ambiente (SEDEMA) da Prefeitura Municipal de Piracicaba, calculou o Índice de Áreas Verdes ${ }^{4}$ do referido município, através da seguinte metodologia:

Foram considerados para o cálculo, áreas de praças, áreas verdes e parques onde são possíveis as atividades de lazer ativo ou passivo, além dos cemitérios. A cidade apresenta 45 praças de tamanhos variados, totalizando $244.680 \mathrm{~m}^{2}$ de área; 03 áreas verdes, com $131.748 \mathrm{~m}^{2}$ de área no total; 04 parques com $348.689 \mathrm{~m}^{2}$ no total, além de 03 cemitérios cuja soma de suas áreas, é $246.446 \mathrm{~m}^{2}$. Quanto a área da ESALQ, foi considerado apenas $50.000 \mathrm{~m}^{2}$, que corresponde ao espaço defronte ao prédio principal, situado dentro do Parque da referida Escola. Trata-se de área sob a égide do Estado, entretanto é muito utilizado pela população da cidade, daí o motivo de ser incluído no cálculo do Índice de Áreas Verdes.

No cômputo total, não incluindo os jardins de representação e o verde viário (rotatórias e canteiros centrais de avenidas), o Município apresenta $1.021 .563 \mathrm{~m}^{2}$ de áreas verdes.

Quanto a população, o último censo realizado no ano de 1991, aponta 283.540 habitantes no Município de Piracicaba, entretanto, para o cálculo de Índice, foi usado 278.715 habitantes, devido a emancipação do município de Saltinho. O Índice de Áreas

${ }^{4}$ Documento da Secretaria Municipal de Defesa do Meio Ambiente da Prefeitura Municipal de Piracicaba SP. Não Publicada. 
Verdes do Município de Piracicaba é de 3,6 $\mathrm{m}^{2} /$ habitante, ao passo que o ideal, segundo a ONU, é $12 \mathrm{~m}^{2} /$ habitante.

\subsection{O Parque da ESALQ}

\subsubsection{Forma}

O Parque da Escola Superior de Agricultura “Luiz de Queiroz” da Universidade de São Paulo, é a principal área verde da cidade de Piracicaba - SP, apresentando uma coleção de espécies botânicas, regionais e exóticas, além de possuir grande valor científico e histórico. O Parque, de grande valia para realização de estudos e atividades didáticas, é muito procurado pela população (Campos, 1991).

Segundo Lima (1987) o Parque foi idealizado pelo arquiteto e paisagista belga Arsenio Puttemans, sendo que o projeto original, teve início de implantação, ao redor de 1905, com o auxílio de Luiz Teixeira Mendes, professor de Fruticultura e Silvicultura da Escola na época, e inauguração em meados de 1907 (Figuras 17 e 18). Pode-se observar na Figura 17, outros maciços e aos fundos, o Prédio Central e o galpão, onde no lugar, foram construídos dois lagos. 


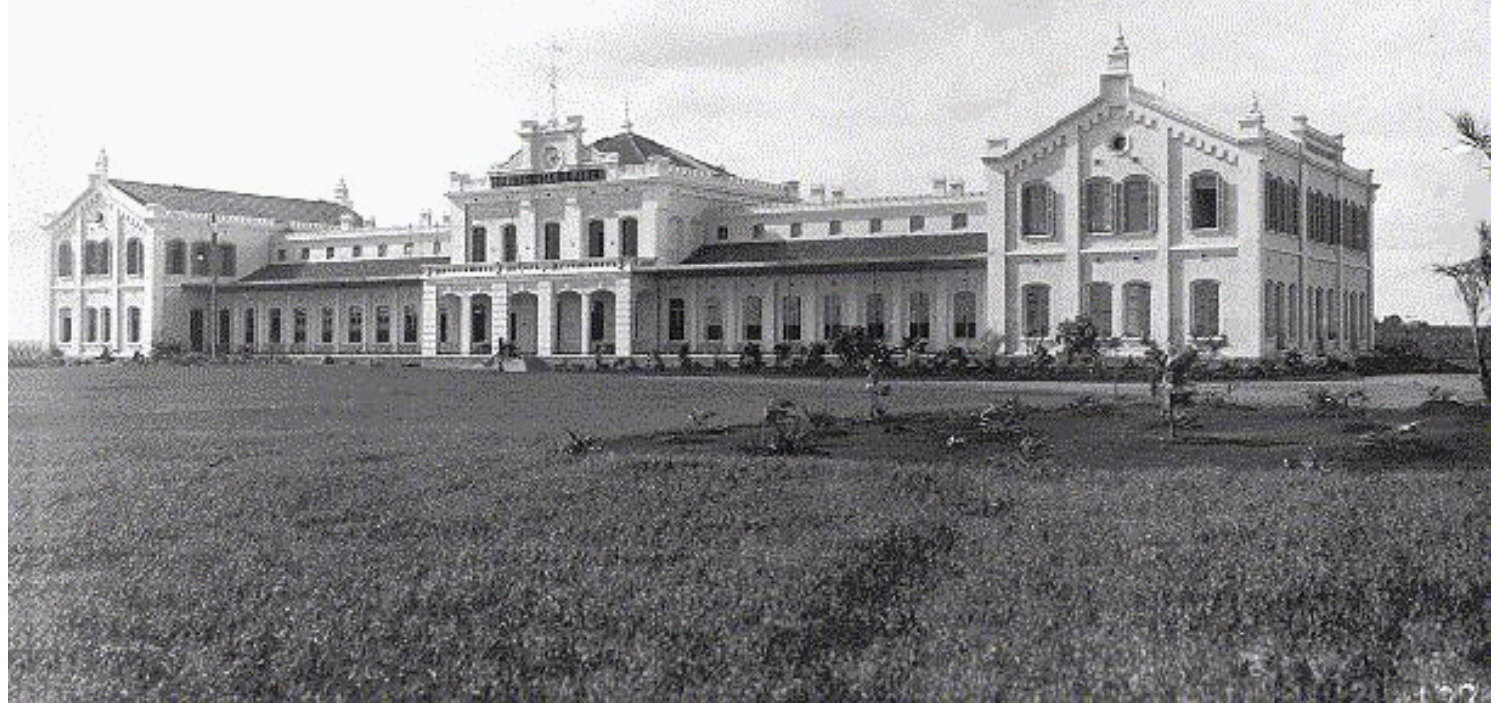

Figura 17. Fotografia ilustrando o maciço 13, logo após a sua implantação.

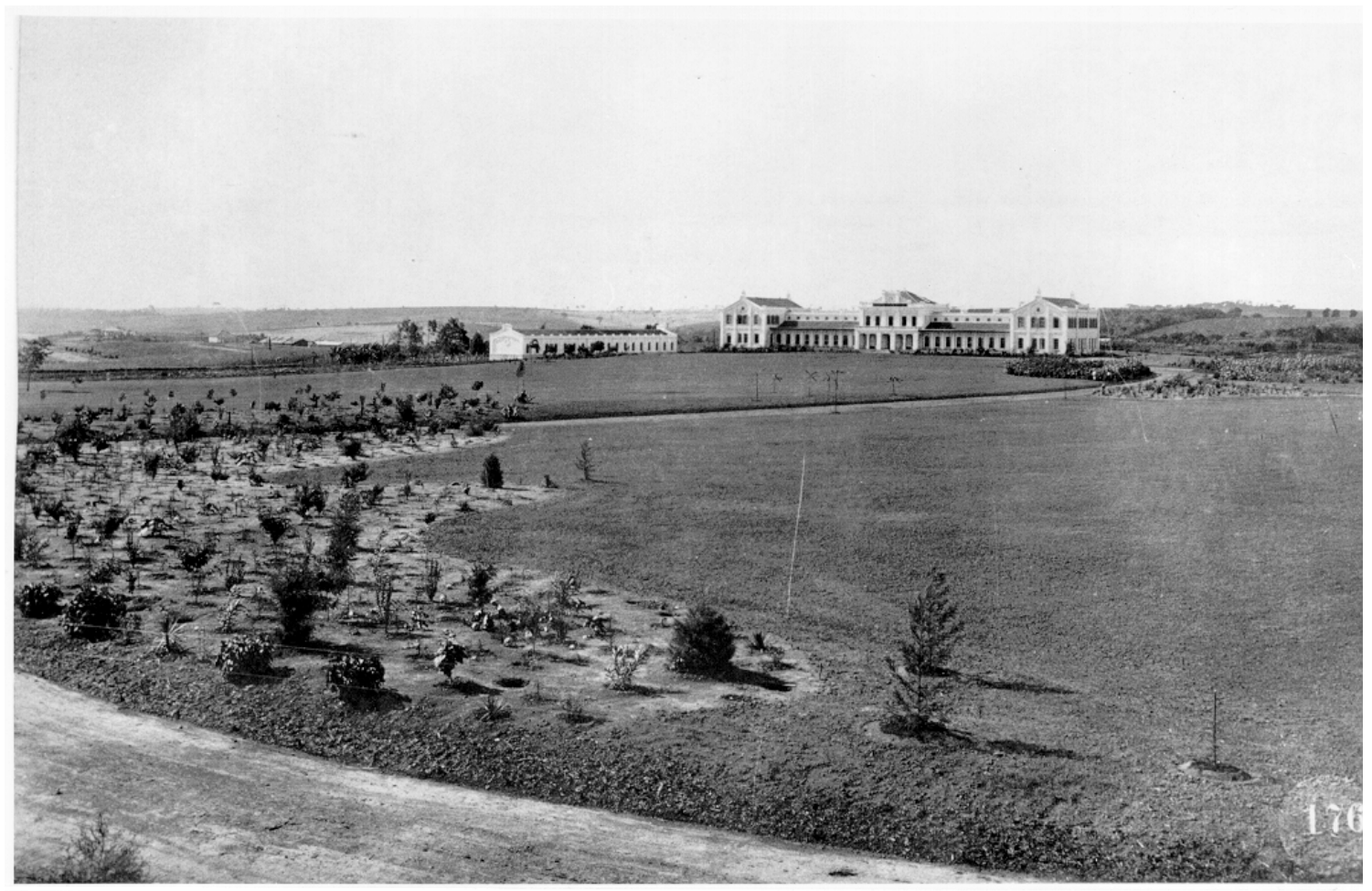

Figura 18. Fotografia ilustrando maciço logo após a sua implantação. 
Cabe lembrar que não se sabe da existência de lista ou sugestão feita pelo idealizador do projeto paisagístico do Parque, referente às espécies vegetais a serem utilizadas no mesmo, ficando, essa tarefa, para os responsáveis pela implantação. Também não se sabe se estes últimos fizeram catalogação das plantas que foram colocadas na área.

O citado projeto, foi quase totalmente implantado, faltando apenas a construção de um coreto, que deveria ser construído na parte frontal-direita do Parque, próximo ao maciço de número 9, conforme pode-se observar na Figura 19. 


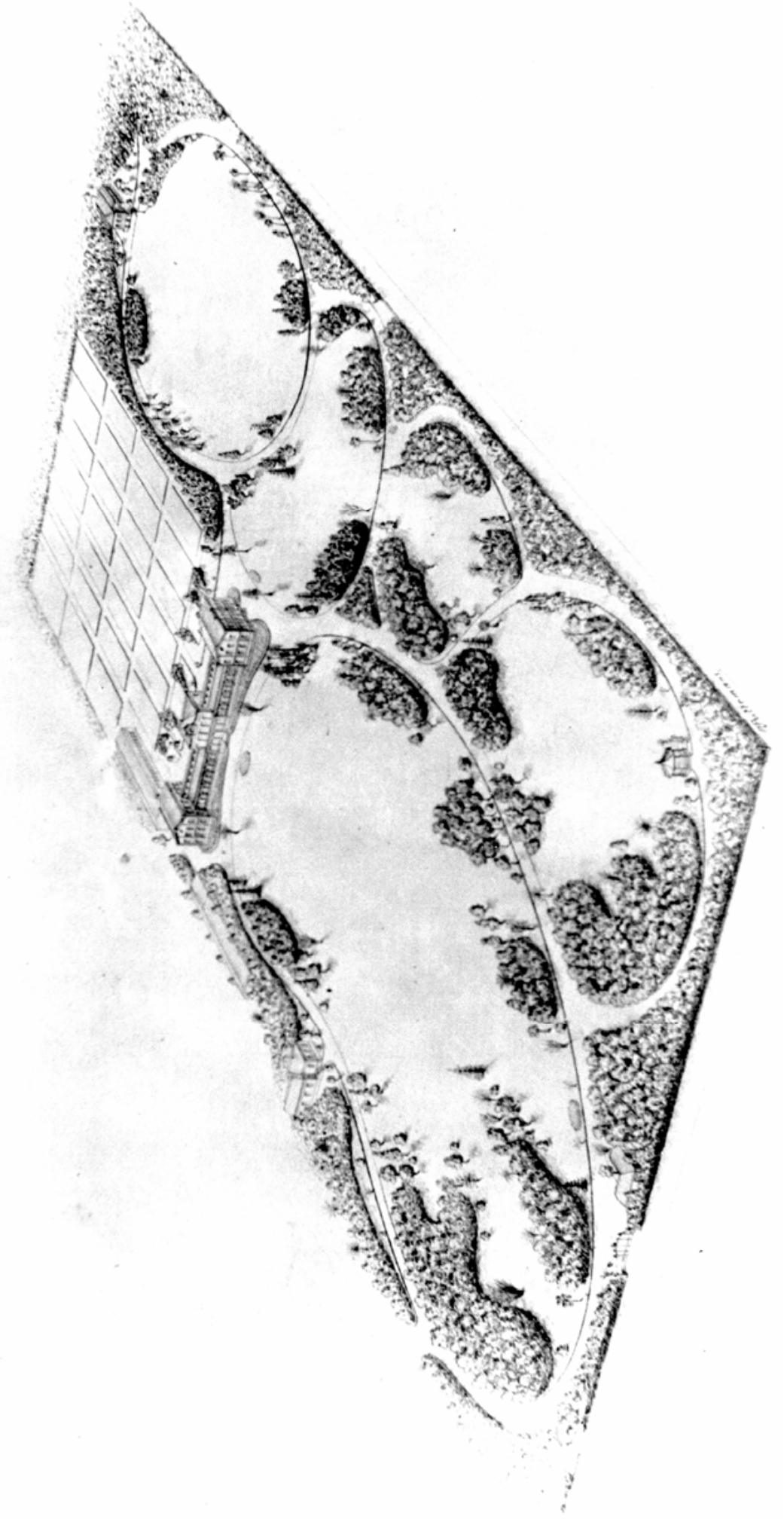

Figura 19. Desenho do projeto original do Parque da ESALQ visto em perspectiva. 
Entre os anos de 1922 e 1959, iniciou-se uma fase de expansão e manutenção do projeto original, sob responsabilidade do Prof. Philippe Westin Cabral de Vasconcellos, que idealizou os canteiros ao redor dos pavilhões de Química (1930), Horticultura (1946) e Engenharia (1947 - 1948), orientando a introdução de espécies tanto nativas como exóticas (Figura 20). Essa dedicação, foi reconhecida e em maio de 1986, o Parque passou a ser denominado oficialmente de "Parque Philippe Westin Cabral de Vasconcellos".

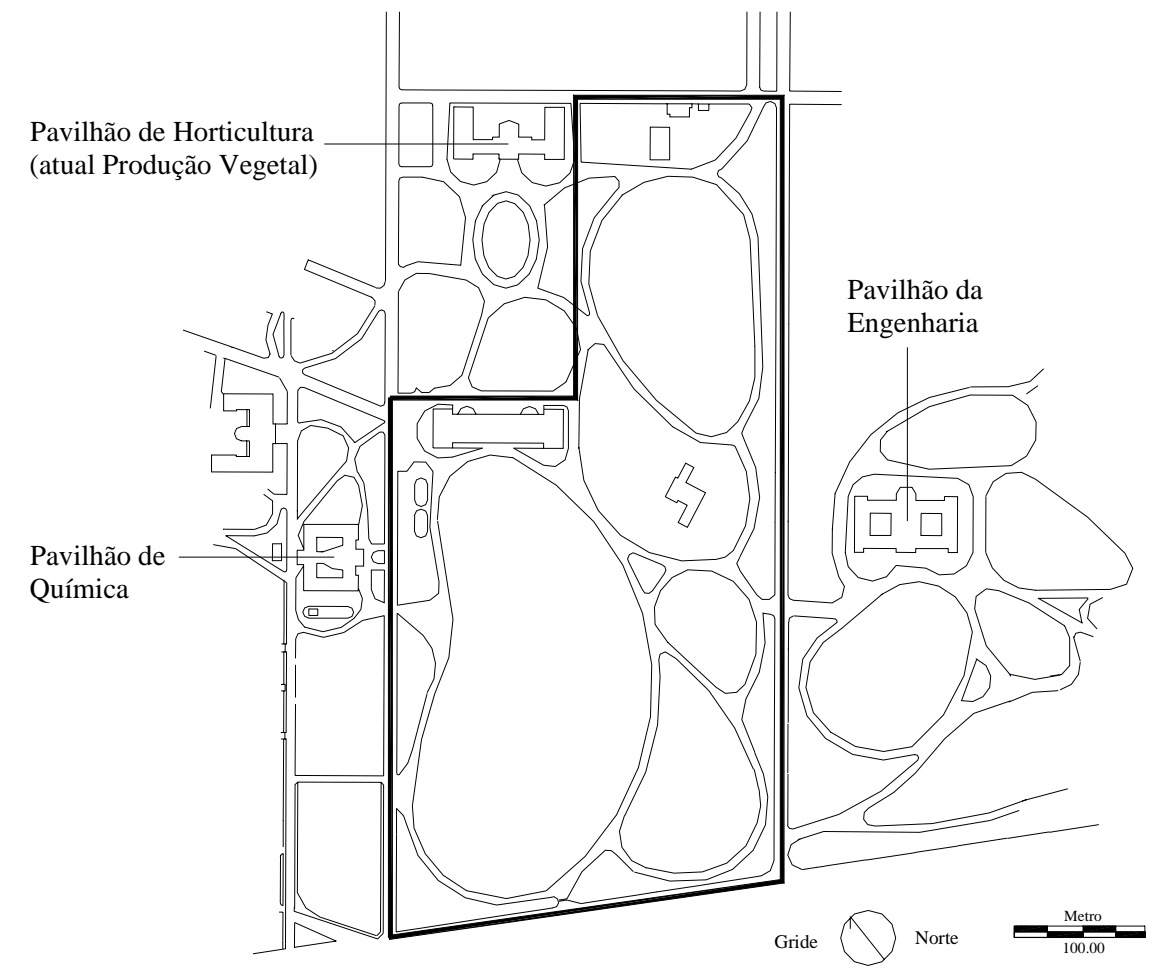

Figura 20. Planta baixa ilustrando a área total do Parque. No destaque pode se observar a área projetada originalmente.

Ocorreram algumas outras modificações, como a construção de dois lagos, na parte esquerda do Parque, em 1935, projetados pelo Prof. Philippe Westin Cabral de Vasconcellos, responsável pelo Parque na época. No local da implantação havia anteriormente um galpão destinado à ginástica e depois, ocupado pelo Laboratório de Química. Estes dois lagos, mais o lago defronte ao Pavilhão de Engenharia (1948) e o defronte ao Prédio da Horticultura (1946), foram construídos para servirem de 
reservatórios de água, na prevenção de incêndios e irrigação de diversas culturas. Tempo depois, por volta de 1966, foi construído um prédio destinado a abrigar a Biblioteca da Escola, onde hoje funciona a Seção de Alunos, que veio descaracterizar o projeto original, ocupando local onde passavam duas linhas de visada, além de ter a fachada de tijolo à vista e concreto, totalmente diferente do material utilizado no Prédio Central e outras construções existentes no Parque. Houve a construção de um portal, na entrada principal do Parque e ainda, a pavimentação de parte de suas ruas e consequente impermeabilização, fato este que, apesar de não estar nas citações de Bellair \& Bellair (1939), contraria os princípios agronômicos, no tocante à infiltração de águas pluviais. Cabe lembrar, que através de observações em outros parques, não importando o Estilo dos mesmos, a prática da impermeabilização dos caminhos, restringe-se a locais necessários.

Como destaque de alta relevância para a comunidade, no Parque, repousam os corpos de Luiz Vicente de Souza Queiroz e o de sua esposa, a Sra. Ermelinda Ottoni de Souza Queiroz. O canteiro de flores que abriga as lápides, encontra-se defronte ao Prédio Central, respeitando o Estilo Inglês apresentado nas Figuras 9 e 14, nas páginas 12 e 18 respectivamente.

Segundo Vasconcellos (1976), em meados de 1941, foi implantado, no gramado central, do Parque, próximo ao Prédio Central, um marco geodésico, doado pelo Governo do Estado, para auxílio nos estudos de astronomia e orientação dos mapas topográficos.

Quando Luiz Vicente de Souza Queiroz, doou as terras para que fosse construída uma Escola Agrícola, o mesmo, segundo relatos colhidos, pediu para que os solos mais férteis ficassem para a lavoura, enquanto a área de solo mais pobre, para o jardim. Portanto, o local onde se construiu o Parque, tinha condições precárias de solo, tendo sido necessário um árduo trabalho de troca de solo, (Figura 21) realizado por vagonetes em trilhos puxados por animais. Mesmo com essa troca de solo, as plantas demoravam muito tempo para crescer, tendo sido acelerado o processo, a partir do momento em que o material vegetal existente embaixo dos maciços, decorrente da queda de folhas, ramos, frutos etc, deixou de ser recolhido, enriquecendo assim o solo. 
Outro fato interessante, é que como o solo local é muito raso, tendo folhelhos de formação Corumbataí, a alguns centímetros de profundidade, nos locais onde seriam implantados os maciços, a deposição de solo foi maior, formando verdadeiros murundus, para que as raízes das árvores, tivessem mais espaço vertical para se desenvolverem. Este fato é citado na revisão bibliográfica sobre o Estilo Inglês de Paisagismo.

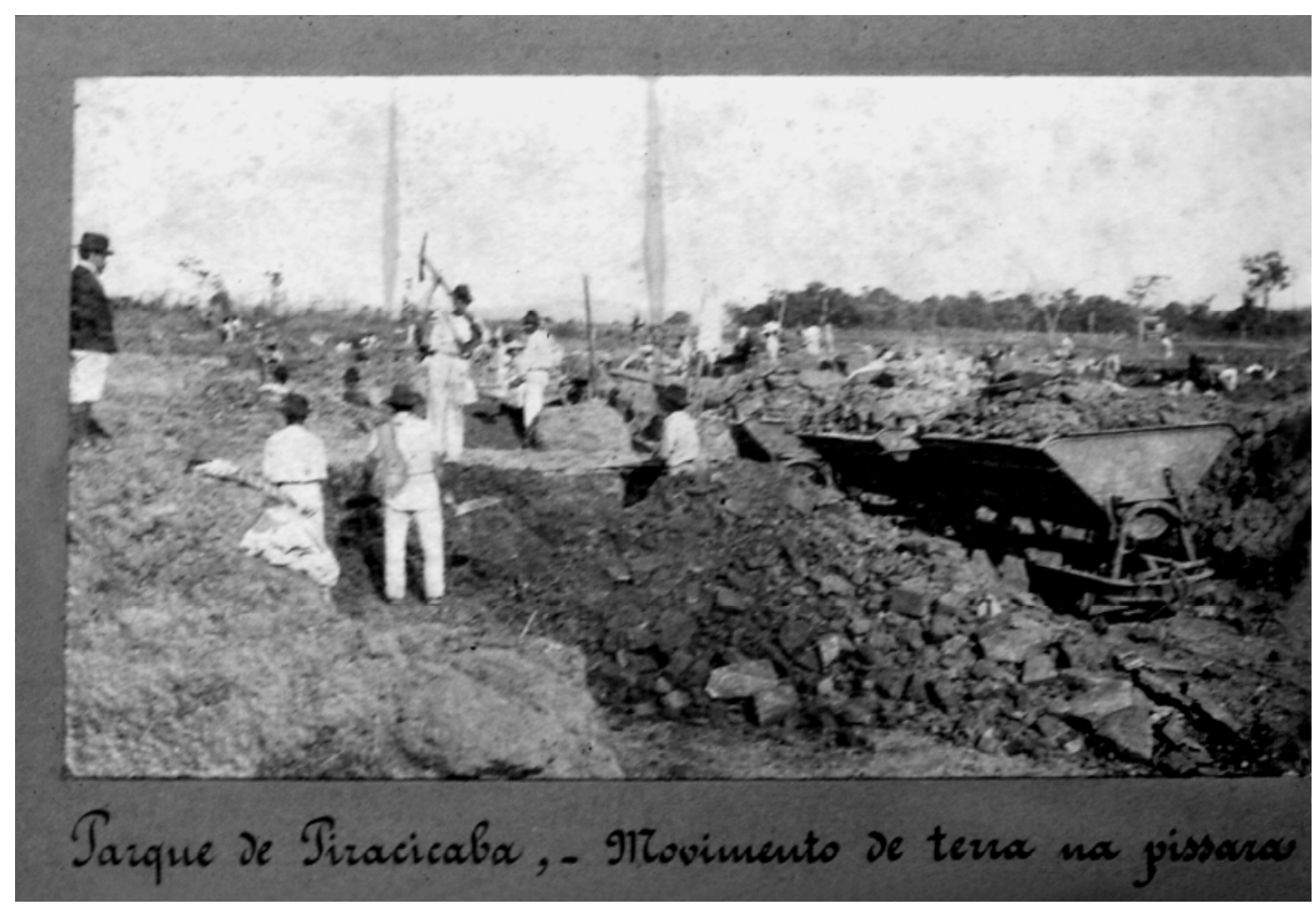

Figura 21. Fotografia ilustrando a troca de solo na implantação do Parque por volta de 1906.

Lima (1987), salienta a importância da conservação do Parque da ESALQ como patrimônio histórico, já que as poucas obras realizadas no Brasil por Arsenio Puttemans, ou seja, o projeto do Jardim do Ipiranga, o da Praça da República e da Várzea do Braz, em São Paulo, bem como a Praça de São Bento, em Niterói (Figura 15 na página 20), o do Parque da ESALQ, é hoje a única que permanece praticamente inalterada. 


\subsection{Levantamentos Florísticos}

Um levantamento florístico consiste em listar todas as espécies vegetais existentes em uma determinada área. Pode-se no levantamento, adotar critérios de seleção, tais como: diâmetro mínimo do fuste, tipo de vegetal etc.

De acordo com Leitão Filho (1982), a identificação das espécies de uma comunidade e a análise de sua estrutura são fundamentais para o manejo adequado de uma formação.

Segundo Rodrigues e Gandolfi (1996), a fitossociologia, é o ramo da ecologia vegetal que procura estudar, descrever e compreender as relações quantitativas entre as espécies em uma comunidade.

Embora o Parque da ESALQ não seja uma formação natural, verifica-se esta necessidade, uma vez que as crescentes interferências antrópicas têm mostrado inadequadas, ocorrendo alta mortalidade de indivíduos e descaracterização do projeto paisagístico original através da retirada e da introdução de indivíduos de forma aleatória (Goldenberg et al., 1991). Ressalta-se também a importância do entendimento dos processos naturais de sucessão que ocorrem no Parque, pois o grande número de espécies existentes, é devido não somente à introdução artificial por ocasião da implantação e da manutenção, mas também a um processo natural de sucessão que ocorre graças a presença, nas proximidades, de remanescentes de matas de planalto, cujas sementes são dispersas pelo vento e por animais. Segundo Kageyama (1986), a sucessão secundária é um processo pelo qual as florestas se auto-renovam através da cicatrização de pontos de distúrbio, formando mosaico de áreas em diferentes estágios de sucessão.

Segundo Gandolfi (1991), as florestas em estágio clímax, ou seja, adulta, podem se apresentar em várias fases de desenvolvimento, podendo estar em: fase de clareira, fase de construção e/ou fase madura. A floresta na fase de clareira, representa a fase inicial do ciclo de crescimento florestal e surge numa área caracterizada em geral pelas condições típicas de fase madura ali existentes. A fase de construção, segue-se ao surgimento de uma clareira o processo de sua ocupação, que pode se desenvolver de 
diferentes formas tais como: sobrevivência de indivíduos jovens ou plântulas já existentes à formação da clareira, rebrota, germinação de sementes existentes ou dispersas de outras áreas etc, sendo muito provável a ocorrência de todos os processos citados, simultaneamente, na ocupação da clareira. Já a floresta em fase madura, é formada em geral por uma estrutura florestal, onde tem-se um dossel (parte superior da cobertura florestal), mais ou menos contínuo formado pelas copas de grandes árvores. Abaixo, observa-se um número muito variado de indivíduos e espécies arbóreas, bem como de outras formas de um vegetal, arranjadas em grau de variada estratificação e submetida a diversas intensidades de sombreamento, formando a região do sub-bosque. Estas fases são contínuas e gradualmente se transformam na fase seguinte, salvo a fase de clareira, que normalmente se dá de modo repentino e algumas vezes catastrófico, pois pode ser formada desde a morte de uma ou mais árvores do dossel florestal ou ainda, independente da morte, da queda de todo o indivíduo ou de parte dele.

Segundo Miller (1997), o plano de manejo de qualquer área deve ser iniciada com a realização de um inventário do local e, neste, devem conter todas as informações necessárias para embasar a realização desse plano.

Segundo Takahashi (1994), o inventário florestal é de extrema importância para o manejo da arborização urbana, levando-se em conta que os responsáveis pelo seu planejamento, quase sempre não dispõe de informações seguras, para traçá-lo. Portanto ele deve realizar inventário e definir as informações a serem coletadas, dependendo do objetivo do manejo. O mesmo autor cita alguns objetivos gerais de manejo:

- conhecer o patrimônio arbóreo;

- definir uma política de administração a longo prazo;

- estabelecer previsões orçamentárias futuras;

- preparar programa de gerenciamento das árvores;

- identificar necessidade de manejo;

- definir prioridades nas intervenções;

- localizar área de plantio;

- localizar árvores com necessidade de tratamento ou remoção (este último, não presente em jardins no Estilo Inglês, onde se preza a proximidade com a natureza); 
- utilizar a árvore como um vetor de comunicação.

São extremamente limitadas as publicações sobre a composição florística de parques implantados, um dos mais antigos trabalhos de que se tem conhecimento é o “Guia Botânico da Praça da República e Parque da Luz” elaborado por Usteri (1919), que lista as espécies vegetais encontradas e as mapeia.

Em 1976 foi publicado o levantamento das árvores da cidade de São Paulo (Cruz \& Câmara, 1976).

São Paulo (1988), realizou um cadastro dos espaços arborizados significativos do Município de São Paulo, levantando, mapeando e identificando conjuntos e exemplares arbóreos significativos no município. São ao todo: 22 parques, 02 reservas, 60 praças e espaços urbanos, 30 áreas institucionais e de uso público, 08 cemitérios, 16 clubes e áreas de recreação, 30 escolas, 22 bairros-jardins, 21 bairros e vias arborizadas, 23 jardins de casas e de edifícios residenciais, 05 indústrias, 08 agrupamentos de vegetação, 06 glebas não ocupadas em áreas urbanizadas, 15 chácaras remanescentes em áreas urbanizadas, 80 exemplares isolados bem como o uso do solo nas zonas rurais.

Segundo Catharino (1989), a riqueza florística inicial do Parque da ESALQ foi completada com introduções de outras espécies arbustivas e arbóreas nativas não usadas inicialmente, mas que chegaram ao Parque pela dispersão de um remanescente de formação florestal de planalto ou floresta estacional mesófila semidecídua, localizada próxima ao Parque, denominada Mata da Pedreira, ao longo do Ribeirão Piracicamirim.

O mesmo autor, ressalta que o Parque também funciona como uma continuidade das matas residuais do Campus, possuindo muitas espécies nativas que se reproduzem e sobrevivem perfeitamente.

Foram realizados vários estudos referentes ao Parque da ESALQ, sendo a maioria deles voltados para as espécies arbóreas. Citamos alguns dentre estes:

- Estudo de identificação de espécies, pragas, época de floração e frutificação e respectivo mapeamento geral, de todo o Parque, realizado em 1965, por Manoel Fadigas de Souza Filho, Engenheiro Agrônomo, Técnico lotado do Instituto Biológico da Secretaria da Agricultura do Estado de São Paulo, com o auxílio do Prof. Dr. Salim Simão, Catedrático da Cadeira no 12 (hoje Horticultura) do Departamento de Produção 
Vegetal da ESALQ. Estas espécies foram catalogadas com as seguintes informações: nome vulgar, família, nome botânico e localização dos maciços de cada canteiro;

- Estudo fenológico das principais espécies arbóreas plantadas no Parque da ESALQ realizado por Engel \& Poggiani (1985), teve como objetivo determinar a época de floração e frutificação das principais espécies arbóreas plantadas no Parque da ESALQ;

- Guia de localização e reconhecimento das principais espécies arbóreas do Parque da ESALQ; realizado por Engel et al. (1985), teve como objetivo, fornecer subsídio para que todas pudessem localizar uma determinada espécie arbórea dentro do Parque, bem como obterem a descrição das folhas;

- Levantamento florístico e fitossociológico dos canteiros do Parque da ESALQ, realizado por Goldenberg et al. (1991), visou um conhecimento detalhado da vegetação para fins de orientação, manejo e conservação da área. Realizou-se um levantamento florístico e fitossociológico da vegetação arbustivo-arbórea existente e todas as espécies foram plaqueadas, mapeadas, medidas (altura e DAP) e identificados todos os indivíduos com DAP maior ou igual a $5 \mathrm{~cm}$. Neste trabalho, foram catalogadas as espécies até o maciço número 22, faltando os maciços 23 e 24.

\subsection{Fotointerpretação e Técnicas Cartográficas}

É indiscutível a importância do uso da fotografia aérea nos levantamentos de solos e vegetação. Rabben (1960), atribui a utilidade da fotografia a três fatores:

a) área expressiva coberta por uma fotografia aérea, ou seja:

- $33 \mathrm{~km}^{2}$ na escala aproximada de 1:25.000;

- 5,29 km² na escala aproximada de 1:10.000;

- 3,39 $\mathrm{km}^{2}$ na escala aproximada de 1:8.000;

- 1,32 $\mathrm{km}^{2}$ na escala aproximada de 1:5.000.

b) visão tridimensional da superfície, através de observação dos pares estereoscópicos; 
c) as imagens dos objetos registrados nas fotografias são permanentes e não tendenciosas, o que permite investigação detalhada e cuidadosa da área no momento que o intérprete achar de conveniência.

Ainda Rabben (1960), relata que as fotografias aéreas verticais possuem algumas limitações tais como: escala utilizada, filme utilizado, época do vôo (durante o ano) e a sofisticação tecnológica. A escala determina a resolução fotográfica e o seu grau de fidelidade.

Efeito de sombreamento e/ou espécies vegetais com folhas decíduas causam distorções que podem atrapalhar a visualização de detalhes na fotografia (Goodwin, 1996).

Goosen (1968), relata que embora o trabalho de campo não seja substituído completamente pela fotografia aérea, o rendimento e a exatidão dos trabalhos são altamente favorecidos.

Loch (1989), afirma que no trabalho de fotointerpretação, deve-se sempre usar uma margem de segurança nas afirmações e conclusões e que a maior ou menor probabilidade de acerto nas deduções, depende basicamente de dois fatores: experiência do fotointérprete e a qualidade do material utilizado.

O mesmo autor cita que a fotografia aérea é um instrumento capaz de representar as formas e o arranjo espacial das plantas, sejam elas dispostas individualmente ou em maciços. O método da fotointerpretação aplicada à vegetação, baseia-se em estudos de tonalidade, textura, sombra, forma e dimensão, além do conhecimento das relações entre a vegetação e o meio ambiente.

Schreuder (1963), relata o uso de fotografias aéreas no manejo de bosques e os resume nos seguintes pontos:

- memória florestal - elas podem mostrar o histórico de uma determinada área, através de fotografias tiradas em épocas distintas. Além disso, são facilmente arquivadas;

- em reconhecimento da silvicultura - podem se usadas para se estudar as plantações, examinar as árvores que estão floridas, com sementes, reconhecer a sua 
regeneração, saber onde há exploração, fogo, em reconhecimento de área infestadas com pragas e doenças etc;

- para fins locacionais - escolher e locar carreadores dentro do bosque, limites de uma propriedade, construções e benfeitorias etc;

- na compra e venda de madeira e do bosque - pode-se estimar a quantidade de madeira existente em determinada plantação, através do estudo em fotografia aérea. Em empreendimentos florestais, a fotografia aérea pode, por exemplo, dar idéia do que existe na área, bem como localizá-la;

- no planejamento de recreação - é usada para localizar áreas potenciais para recreação como lagos, rios, campings, montanhas etc;

- no manejo da vida silvestre e pastoreio - para reconhecer os pastos presentes na área, avaliar as condições atuais para a vida silvestre e o gado, a situação de rios, lagos e as fontes de forragem, além de planejar atividades para melhorar estas condições.

A escala é um fator muito importante nos trabalhos envolvendo a fotointerpretação e vegetação. Bradshaw citado por Heinsdijk (1952), relata que na fotointerpretação de florestas, com fotografias pancromáticas (vários tons de cinza) na escala 1:20000 ou menor, é possível apenas demarcar e avaliar áreas de diferentes tipos de vegetação.

Spurr (1948), enumera algumas características qualitativas e quantitativas presentes na fotointerpretação. Como características qualitativas, os principais elementos básicos de reconhecimento utilizados na fotointerpretação de vegetação são:

- tonalidade - para fotografias pancromáticas, a tonalidade varia do completamente banco até o preto, passando pelos vários tons de cinza. Essas tonalidades diferentes, permitem identificar os tipos de vegetação;

- forma - auxiliam a identificação na fotografia, da área selecionada para o estudo. Em estudos de vegetação, os talhões bem separados, maciços com bordas definidas etc, auxiliam o trabalho do fotointérprete;

- padrão - se caracteriza pela união ou extensão das formas. Pode ser aproveitado para auxiliar o fotointérprete quando de fácil reconhecimento (Ex: rede de drenagem, 
enxadrezado das cidades, formado por ruas retilíneas e transversais). Na vegetação, a uniformidade da cobertura, pode ser um fator de auxílio ao fotointérprete;

- textura - vem do arranjo de muitos elementos iguais ou similares que estão numa mesma área ou que, em conjunto, compõem um objeto. A textura pode ser classificada de muito grosseira até super fina e está ligada à escala da fotografia aérea. Uma mesma floresta, pode ser representada com textura fina em fotografia em escala 1:50000 e grosseira em escala 1:5000. A textura está relacionada com a homogeneidade do dossel;

- tamanho - o tamanho do objeto real, representado na fotografia, está estritamente ligado à escala. Pode-se saber o tamanho do objeto de interesse, medindo-o na fotografia, desde que se saiba a escala. Em floresta, a vegetação pode ser caracterizada como alta, média e baixa;

- sombra - é de grande valor para a fotointepretação. Pode dar noção de altura do objeto de interesse, além de facilitar sua identificação. Na vegetação é de grande valia, uma vez que através dela, pode-se reconhecer a forma do tronco, da copa, o tamanho da árvore e até, em alguns casos, a sua identificação. Tem também o aspecto negativo que é o de obscurecer detalhes;

- posição - a posição geográfica e regional, está relacionada ao entendimento ou à familiarização com a região geográfica fotografada, auxiliando na determinação da vegetação;

- adjacências - é junção de todos os elementos citados, que facilitam a interpretação.

Como características quantitativas, entram as informações que podem ser medidas nas fotografias, que podem ser vistas a seguir:

- densidade - muito importante para vegetação e depende da escala da fotografia. A densidade de copa, por exemplo, corresponde à porcentagem do terreno coberto por esse tipo de copa. Pode-se através dela, estimar povoamentos existentes em uma determinada área. Porém, essa estimativa deve ser acompanhada pelo uso da estereoscopia pois, pode-se cometer erros de operação na obtenção da área, incluindo-se nela, sombras existentes na fotografia. 
- tamanho - além da avaliação qualitativa, pode-se obter vários índices de tamanho com medições realizadas nas fotografias. São elas: distância horizontal (distância entre plantas, entre pontos etc), distância vertical (altura de árvores etc), área (de maciços, prédios etc) e diâmetro de copa (muito usado na obtenção do volume da árvore e povoamento).

Pode-se também identificar e mapear os tipos de cobertura vegetal. A metodologia depende do grau de detalhamento que se quer. Para auxiliar a identificação, pode-se utilizar chaves de interpretação. Rocha (1986), classifica a vegetação da seguinte forma:

- gramináceas (monocotiledônea);

- herbácea (ausência de arte lenhosa);

- arbustiva (vegetais ramificados desde a base que crescem até 5 metros de altura);

- arbóreas (plantas lenhosas de grande porte).

A diferenciação entre os tipos citados acima se dá, para fotografias aéreas pancromáticas, de acordo com a seguinte chave:

- gramináceas - tonalidade cinza claro a cinza médio, textura suave a fina, distribuição homogênea;

- herbáceas - tonalidade cinza médio, textura fina a levemente rugosa, distribuição heterogênea;

- arbustiva - tonalidade cinza médio, textura rugosa;

- arbórea - tonalidade cinza médio a cinza escuro, textura rugosa a áspera.

Mendonça et al (1980), relata que toda vegetação de porte baixo (campos gramados, pastagens etc) aparecem com tonalidade clara, quando não se encontram em áreas extremamente úmidas. Já a cobertura vegetal densa (como áreas reflorestadas e floresta natural), aparecem com tonalidade escura.

O mapeamento aerofotogramétrico, planialtimétrico e cadastral deve ser obtido de forma numérica (coordenadas x e y e altitude/cotas de cada ponto), através da captura e armazenamento digital das feições, organizado por níveis (layers), sendo que em cada 
escala apresentem curvas de nível em espaçamento compatível para os vazios dos maciços arbóreo/arbustivo e das ruas.

Segundo Avery (1978), dependendo da finalidade do levantamento, os mapas de cobertura vegetal, podem ser classificados em:

- mapas não controlados - onde as medições de áreas, distâncias e ângulos não são críticas, podem-se preparar mapas não controlados, com a mesma escala das fotografias e por traçado direto;

- mapas controlados - confeccionados quando é necessário precisão nas medições. A escala é uniformizada pela correção das distorções próprias das fotografias aéreas, que é o realizado neste trabalho.

\subsection{Sistema de Informação Geográfica (SIG)}

Alves (1990) explica que Sistemas de Informação Geográfica (SIG) são sistemas destinados ao tratamento de dados referenciado espacialmente. Estes sistemas manipulam dados de diversas fontes como mapas, fotografias aéreas, imagens de satélites, cadastros e outras, permitindo recuperar e combinar informações e efetuar os mais diversos tipos de análise sobre os dados.

Já Calijuri \& Rohm (1993), definem SIG como sendo uma junção de hardware, software, dados geográficos e pessoal, que podem capturar, armazenar, atualizar, manipular, analisar e apresentar informações referenciadas geograficamente.

Um SIG é composto basicamente pelos seguintes módulos (Eastman, 1995):

- sistema cartográfico;

- sistema de digitalização de mapas;

- sistema de gerenciamento de bancos de dados;

- sistemas de análises geográficas;

- sistema de processamento de imagens;

- sistema de análises estatísticas. 
As imagens cartográficas são digitalizadas e os dados são armazenados no banco de dados cartográficos, que é uma coleção de dados espaciais e de dados descritivos relacionados e organizados para facilitar o armazenamento e a utilização pelos usuários.

Na digitalização, que pode ser realizada em três formas distintas (manual, semimanual e automática), os dados espaciais representados por mapas e imagens, são transformados em forma digital. Esta nova forma de representação de dados, pode ser utilizada num SIG.

A digitalização manual é realizada através de mesa digitalizadora e a semimanual (ou semi-automático) é realizada usando-se processo manual adicionado ao método automático. Já a automática, é feita através da utilização de scanner, que tratase de um dispositivo ótico-eletrônico composto por uma fonte de luz e um sensor ótico (fotocélula). O funcionamento da referida máquina, consiste da emissão de um feixe de luz que atinge a superfície do mapa e é refletido e registrado por um sensor (Reis, 1995).

Através do uso dessa metodologia surge a fotogrametria digital, que faz uso de métodos analíticos de cálculo, não utilizando mais imagens na forma de negativos, diapositivos ou papel (utilizados na fotogrametria analítica), mas de imagens digitais via softwares específicos (Rosalem, 1997).

O mesmo autor cita que o número de DPI`s, que traduzindo para o português, significa "pontos por polegada", utilizado no processo de leitura da fotografia pelo scanner, deve ser ajustado de acordo com a escala da fotografia e com a resolução necessária para se ter sucesso nos trabalhos posteriormente executados. Ajustada a resolução, deve-se mantê-la nos processos seguintes de exportação/importação da imagem obtida, para os softwares a serem utilizados, bem como no monitor vídeo do microcomputador utilizado.

Dos vários SIGs existentes, o software IDRISI, elaborado pela Clark University, é muito utilizado para trabalhos de georeferenciamento e tratamento de imagens. Segundo Eastman (1995), trata-se de um software para Windows que tem por função, facilitar a análise de dados geográficos. Esses dados geográficos são descritos na forma de planos de informação que, sobrepostos, compõem um único mapa. 
As análises são feitas em planos (ou camadas) de informação, embora para a exibição, estes devem ser reunidos, formando uma composição.

Sendo os dados geográficos de tipos diferentes, o IDRISI incorpora duas formas básicas de plano de informação: plano de informação de imagem (raster) e plano de informação vetorizado, onde:

- os planos de informação de imagem, descrevem uma região do espaço, por meio de matriz de pixels. Cada um desses pixels, contém valores numéricos que expressam a natureza da terra àquela localização. Planos de informação de imagens, são excelentes para descrever especialmente dados contínuos, tais como: elevação, níveis de biomassa, temperatura e dados de chuva.

- os planos de informação vetorizados são úteis para descrever características distintas na paisagem, tais como: estradas, limites de propriedades, distritos administrativos etc. Planos de informação vetorizados, armazenam um conjunto de pontos (cada referência por um par de coordenadas de localização) que descrevem a característica da localização (no caso de pontos) ou o curso e limite (no caso de linhas), por meio de sucessão de pontos unidos.

O monitoramento ambiental, planejamento urbano e regional, estudo de recursos terrestres, controle de redes de transporte, de distribuição de energia etc, são exemplos de áreas que vêm se servindo dos SIGs.

Guo et al.(1995), estudaram os impactos na mudança do clima na distribuição do Pinus tabulaeformis na China. Modelos de correlação ente distribuição geográfica do Pinus e condições climáticas foram desenvolvidos baseados no IDRISI. Possivelmente pode-se predizer a sua distribuição em 2003 usando esses modelos. Resultados mostram que o Pinus tabulaeformis tem potencial de distribuição ligeiramente voltada em direção ao norte, com a parte oriental limite norte, mudado para $1,4^{\circ} \mathrm{N}$ e o seu limite sul para $0,2^{\circ} \mathrm{N}$. Esta potencial distribuição em área diminuiu em 9,4\% comparando com a presente distribuição devido ao movimento leste e oeste da extremidade interna. A área central, teve diminuição de 7\%, principalmente devido ao movimento do limite sul.

Machin \& Navas (1995), fizeram a regionalização das zonas áridas, semiáridas e sub-úmidas secas do México e a amplitude do uso do solo de acordo com o potencial 
produtivo de cada região. Para isso, formaram uma base de dados georreferenciados de fatores físicos de clima, solo e topografia com disposição a ser manipulados em GISIDRISI, mediante a técnica de reclassificação e álgebra de mapas. Pela natureza das informações, os resultados estão em mapas dos Estados compreendidos nas zonas áridas e semi-áridas nas quais são delimitadas as zonas áridas semi-áridas e sub-úmidas secas, assim como a publicação das áreas com potencial produtivo para diferentes vegetais. As informações facilitam a manipulação e informação e integra todos os fatores envolvidos no processo produtivo, facilitando o bom planejamento da área.

Kamaruzaman \& Mohd-Rasol (1995), usaram sensoriamento remoto para monitorar o desmatamento na Sungai Buloh Forest Reserve, na península da Malasia. Este estudo foi feito para avaliar a viabilidade de utilização do Landsat TM. Foram detectados dados entre 1988 e 1991. No IDRISI, as imagens foram processadas. Os estudos revelaram que a taxa de desmatamento é de 182 ha/ano, com precisão de $90 \%$.

\subsection{Medição de Área}

Tem-se o conhecimento de apenas alguns estudos onde se mediu o crescimento em área de vegetação. Batista (1982), realizou estudo a fim de estabelecer metodologia para identificar a fitofisionomia da vegetação de Cerrado baseando-se na fotointerpretação de imagens obtidas através de fotografias aéreas verticais. O trabalho realizado na Reserva Biológica de Moji-Guaçu, em Moji-Guaçu-SP, consistiu de estudo da evolução desse tipo de vegetação, que foi realizada por fotointerpretação das imagens dos anos de 1962, 1972 e 1978. As áreas de vegetação com tonalidade e textura distintas, foram delimitadas e posteriormente demarcadas em cartas. A comparação dessas cartas permitiu avaliar as mudanças na fisionomia da vegetação que se evidenciou no período de 1962 a 1978.

Silveira (1999), realizou mapeamento geo-ambiental do Horto Matão, fazendo parte do "Projeto de Recuperação e Manejo das Áreas de Reserva do Horto Matão” localizado no município de Selvíria - MS. Visando estudar a evolução das coberturas vegetais na área ao longo dos anos, foram analisadas as imagens dos satélites 
LANDSAT e SPOT, dos anos 1980, 1984, 1990 e 1994. Através dessas imagens, podese demarcar as áreas das diferentes vegetações e, através do seu confronto, observar as modificações ocorridas, bem como sua dinâmica. Os resultados mostram grande decréscimo da área ocupada pelo cerrado (em 1980 representava 75\% da área total estudada e em 1994 caiu para 17\%) e aumento na área de pasto (em 1980 representava 25\% da área e em 1994 subiu para 80,5\%), além do aparecimento de 2,5\% entre os anos de 1984 e 1990, de áreas destinadas ao reflorestamento, que se mantiveram até 1994.

\subsection{Projetos Paisagísticos}

Jairo Ribeiro de Mattos ${ }^{5}$, explica que, quando se planeja um projeto paisagístico, de grande porte (macropaisagismo), que compreendem áreas maiores de $10000 \mathrm{~m}^{2}$, as dimensões das representações dos objetos nele utilizados, refletem a realidade do local após 20 anos da implantação. Já no de pequeno porte (micropaisagismo), que compreendem áreas menores de $10000 \mathrm{~m}^{2}$, refletem 10 anos após a implantação. Esta afirmação é também do paisagista, de grande expressão mundial, Roberto Burle Marx, quando visitou o Parque em 1990. Segundo ele, "um jardim leva até mais de 20 anos para alcançar a forma projetada por seus idealizadores" (sic). Assevera ainda: "Nem sempre as pessoas têm paciência para esperar tanto tempo. Mas é necessário que seja assim, porque nós não construímos as coisas só para o momento, e sim para o futuro"(Wildner, 1995).

Rodolfo Ricardo Geiser ${ }^{6}$, relata que, na prática, para um bosque heterogêneo, é estimado, que o mesmo atinja o tamanho, em área, das representações feitas em planta baixa, por volta de 20 anos após sua implantação.

E ainda, Vassão \& Soares (1996), comentam que ao se planejar um projeto de paisagismo, deve-se atentar para a escolha das espécies a serem utilizadas na execução,

\footnotetext{
${ }^{5}$ Ex-professor do Departamento de Produção Vegetal (antigo Departamento de Horticultura).

${ }^{6}$ Engenheiro Agrônomo - Paisagista e Meio-ambientalista (Informações verbais).
} 
pois um erro nesta etapa do projeto, aparecerá no futuro e muitas vezes, pode ser irrecuperável.

Segundo Montenegro (1983), na execução de um projeto paisagístico de parque, deve-se demarcar a área destinada a maciço, gramado, canteiro de flores etc e através de periódicas intervenções, manter essas áreas mais semelhante possível ao proposto pelo projetista. Para se obter sucesso na realização de um projeto paisagístico, devem ser usadas espécies vegetais que se adequem às condições climáticas, pedológicas, de drenagem etc do local destinado à implantação do projeto. 


\section{MATERIAL E MÉTODOS}

\subsection{Material}

O trabalho foi realizado no Parque da Escola Superior de Agricultura "Luiz de Queiroz” da Universidade de São Paulo, Campus de Piracicaba - SP, situado à latitude 2242'30,9”'S e longitude 47³8'01,2”W e 547 m de altitude.

Segundo o sistema Köppen, o clima da região onde está inserido o Parque, é do tipo Cwa (temperatura quente com estiagem no inverno, com temperatura do mês mais quente, superior a $22^{\circ} \mathrm{C}$ e do mês mais frio, inferior a $18^{\circ} \mathrm{C}$ ), com predominância de pluviosidade anual de 1.200 a $1.300 \mathrm{~mm}$ (Setzer, 1946).

A área trabalhada é de aproximadamente 15 hectares, projetada pelo arquitetopaisagista Arsenio Puttemans e apresenta o desenho original. É formada por canteiros de tamanhos e formas variadas, separados por ruas e compostos por 5 gramados e 24 maciços arbóreo/arbustivos, sendo o de número 24, dividido em 7 mini-maciços (a, b, c, d, e, f e g). Apresenta ainda, algumas construções tais como: Prédio da Administração (Prédio Central), Prédio da Seção de Graduação, Prédio do Serviço Odontológico e o Prédio da Microscopia Eletrônica, além de um canteiro que circunda o Prédio da Administração (Figura 22). 


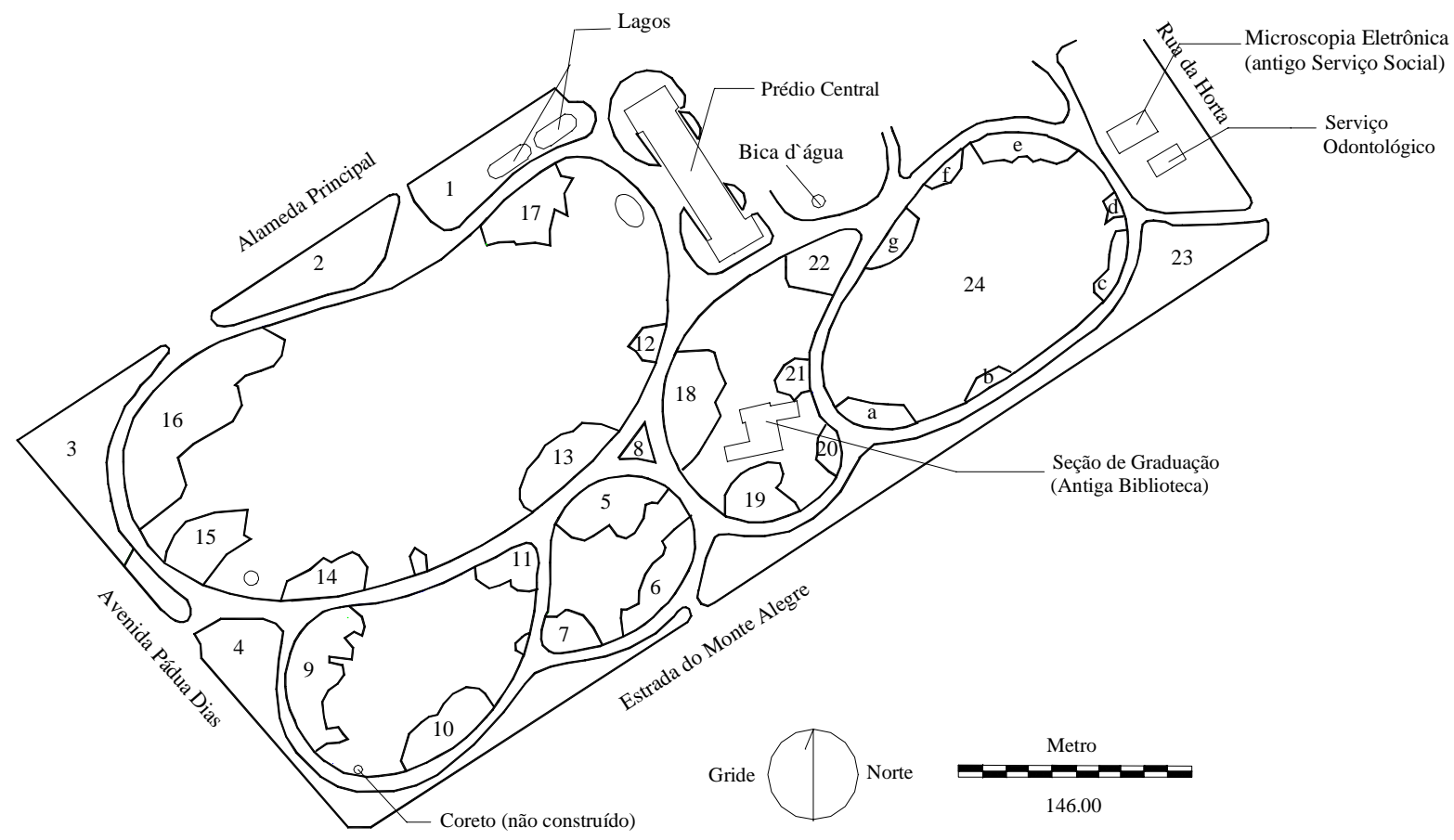

Figura 22. Mapa com os prédios e os nomes das ruas que delimitam o Parque e os números dos maciços arbóreo/arbustivos estudados.

Como pode-se observar na Figura 22, o Parque delimita-se à direita, pela Estrada do Monte Alegre; na porção frontal, pela Avenida Pádua Dias; à esquerda, pela Alameda Principal, até o Prédio da Administração (Prédio Central), onde, se reinicia formando linha reta que vai da lateral direita do Prédio Central, até o prédio da Microscopia Eletrônica. Aos fundos, delimita-se pela parte traseira do Prédio Central e depois, pela Rua da Horta.

O terreno sobre o qual foi implantado o Parque é um aterro, suavemente ondulado (Ranzani, 1965) e portanto não pode ser enquadrado em nenhuma classificação de solo (Figura 23). 


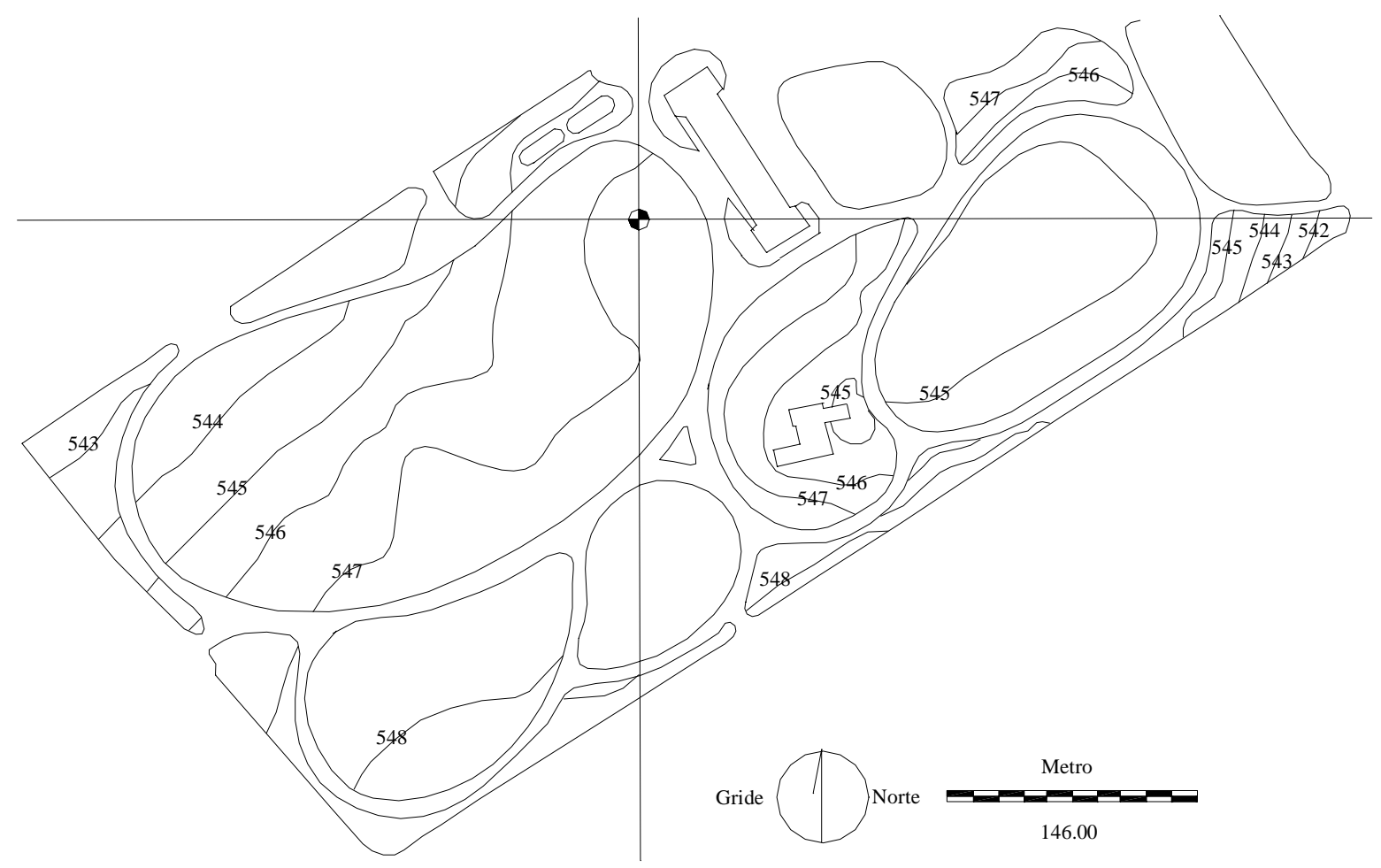

Figura 23. Planta baixa mostrando o relevo do Parque.

Para a realização deste trabalho, foram utilizados os seguintes materiais: microcomputador PC 486 e Pentium II ; Scanner Scanjet 4c; software IDRISI para Windows, software Adobe Photoshop 5,0 para Windows, software Autocad 14 para Windows, distanciômetro eletrônico, levantamentos florísticos realizados em 1965 e 1991, software Access 2.0 para Windows, software Excel 5.0, para Windows, planta baixa do projeto original do Parque (Figura 24) e fotografias aéreas verticais da região, de épocas diferentes. 


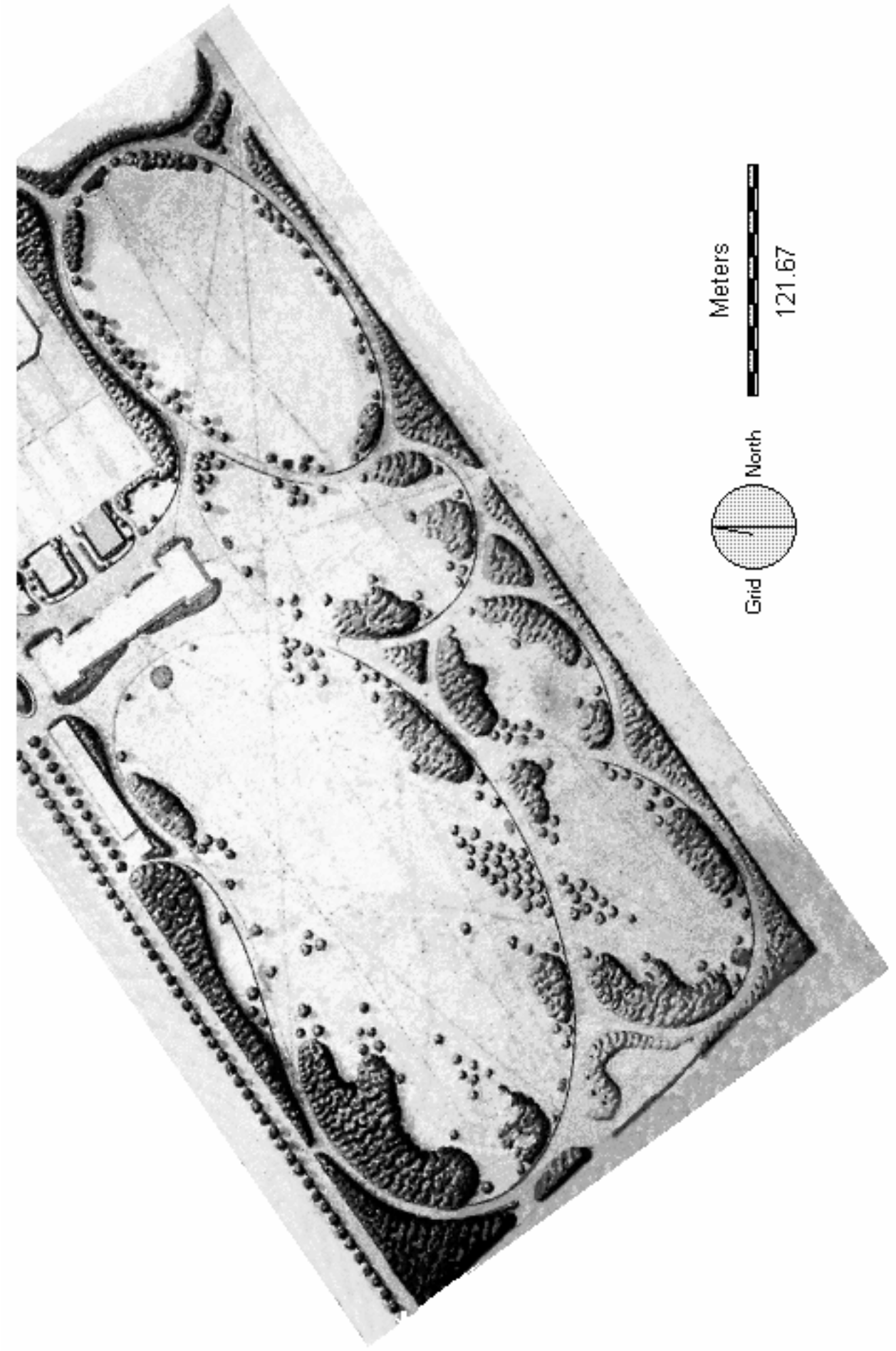

Figura 24. Projeto original do Parque da ESALQ. 
Procurou-se adquirir o máximo e na maior amplitude possível, em anos, de fotografias aéreas verticais da região de Piracicaba - SP, para se ter estudo mais completo possível da área em questão. As fotografias aéreas verticais adquiridas são as seguintes:

- 1945 - aerolevantamento executado pela Aeromapa Brasil, na escala de 1:10000;

- 1962 - aerolevantamento executado pela Aeromapa Brasil, na escala de 1:25000;

- 1969 - aerolevantamento executado pela Vasp Aerofotogrametria, na escala de 1:8000;

- 1973 - aerolevantamento executado pela Vasp Aerofotogrametria, na escala de 1:8000;

- 1993 - aerolevantamento executado pela BASE Aerofotogrametria, na escala de 1:5000;

- 1995 - aerolevantamento executado pela BASE Aerofotogrametria, na escala de $1: 25000$.

Todas as fotografias acima citadas, possuem dimensões de $23 \mathrm{~cm}$ x $23 \mathrm{~cm}$, com recobrimento aproximado de $60 \%$ entre fotografias na faixa de vôo e $30 \%$ entre fotografias das faixas adjacentes.

\subsection{Métodos}

As fotografias aéreas das épocas mencionadas, foram rasterizadas utilizando do scanner, procurando-se obter maior definição possível nas imagens, embora, como enfatiza Spurr (1948), o fator sombra se apresentou em algumas fotografias, com seu aspecto negativo de obscurecer alguns detalhes. A base para se determinar o número de pontos por polegada (dots per inch - DPIs) para cada escala, foram as imagens em escala 1:25000, por apresentarem menor resolução. Testaram-se várias alternativas na rasterização das fotografias e a imagem de maior definição encontrada, ou seja, a visualmente mais bem definida pelo digitalizador, foi quando se utilizou 2000 DPIs. Nas 
outras imagens, para se ter a mesma definição da primeira, pegou-se o número dividendo da escala e o dividiu pelo número de DPIs utilizados (25000/2000), obtendo-se assim, o fator 12,5. A escala dividida por esse fator, fornece o número de DPIs a serem utilizados nas outras imagens, ou seja:

- escala 1:10.000: $\quad 10.000 / 12,5=800$ DPIs;

- escala 1:8.000: $\quad 8.000 / 12,5=640$ DPIs;

- escala 1:5.000: $\quad 5.000 / 12,5=400$ DPIs.

As imagens foram importadas pelo software IDRISI, onde as deformações causadas pela lateralidade da fotografia aérea vertical, foram geometricamente corrigidas, usando-se coordenadas topográficas obtidas com distanciômetro eletrônico, em campo. Antes de efetuar a correção, foram executados controles através de medições de áreas adjacentes ao Parque, utilizando-se do distanciômetro eletrônico e comparandoos com os obtidos pelo IDRISI. A média do erro encontrada, foi de apenas $0,16 \%$, sendo, portanto, desconsiderado neste estudo. Os ajustes de configuração do microcomputador, no painel de controle, foram efetuados a fim de não se perder a definição obtida nos passos realizados anteriormente. Em seguida, os maciços foram digitalizados com o uso do mouse no IDRISI (digitalização em tela), para obtenção analítica das áreas. Cabe lembrar, que na fotografia aérea vertical, as copas das árvores são projetadas no solo e, portanto, a área de um determinado maciço, equivale à área de projeção da copa e não do limite real do maciço. As dúvidas entre áreas sombreadas e áreas de interesse, representada pelos dosséis dos maciços, foram sanadas através do uso de pares estereoscópicos. A área de cada um dos 24 maciços foi calculada usando-se o módulo AREA, um dos apresentados no IDRISI. O referido software, permite criar layers mostrando imagens contendo os maciços, de cada data estipulada. Estes foram sobrepostos, a fim de facilitar a observação das transformações ocorridas nos maciços.

Nas fotografias aéreas obtidas no vôo de 1969, a área do Parque foi desmembrada e portanto, captada por duas fotografias sequenciais, na mesma faixa, tendo sido necessário, para a obtenção da área do maciço de número 23, a utilização de fotografia subsequente à utilizada para a obtenção das áreas dos demais maciços. 
Para se saber quais os maciços que tiveram o maior crescimento relacionado ao período estudado, calculou-se a razão de crescimento para cada maciço. O cálculo foi feito a partir das medições dos anos 1945 e 1995, que é a maior amplitude, em anos, das fotografias aéreas obtidas. No cálculo, dividiu-se a área de cada maciço obtida em 1995 pela área do mesmo em 1945.

A fim de verificar se existe uma relação linear entre as áreas dos maciços arbóreo/arbustivos obtidas em 1945 e 1995, foi ajustado um modelo de regressão linear aos pares de dados.

Para o estudo das linhas de visada, propostas no projeto original, realizou-se, com auxílio do distanciômetro eletrônico, levantamento em campo, onde se delimitaram os perímetros de todos os maciços arbóreo/arbustivos, tomando-se como base os limites maciço-gramado, maciço-guia e gramado-guia. Em locais onde as copas das árvores se curvavam para baixo, ficando a altura inferior aos olhos do observador, tomou-se como base, para definir o limite gramado-bosque, a projeção da copa no solo. Esta metodologia foi adotada para se ter o real ângulo de visualização do observador, pois, estando a copa da árvore abaixo da citada altura, a linha de visualização é interrompida. Estes dados, foram exportados para o software Autocad 14, onde montou-se a planta baixa do Parque.

As linhas de visada, característica importante do Estilo Inglês de paisagismo, foram traçadas sobre imagem da referida planta baixa do Parque, formando um layer, através de observações visuais feitas no projeto original. Além disso, criaram-se layers contendo: os prédios existentes no Parque, nomes dos prédios, nomes das ruas, guias das ruas e os maciços com seus respectivos números (Figura 22). Pôde-se através desse mapa, analisar quais as visadas estão interrompidas, quais as ainda visíveis e saber o que está interrompendo. Para isto, realizou-se levantamento florístico, in loco, nos maciços que estão impedindo a visualização, para saber quais e quantas árvores estão ali presentes.

Este levantamento (in loco), foi realizado com a ajuda do Eng. Agr. João Chaddad filho, responsável pela manutenção do Parque, por vários anos. 
Sabe-se de antemão, que o prédio construído em 1966, em um dos gramados do Parque, para servir de biblioteca da Escola (hoje Seção de Graduação e Pós-Graduação), obstruiu duas linhas de visadas imaginárias. A primeira, partia do Prédio onde hoje abriga a Microscopia Eletrônica e ia até o Coreto (não construído), que estaria localizado na área frontal do Parque, próximo à Avenida Carlos Botelho, conforme pode-se observar na Figura 25, e a segunda, ia da entrada do Parque, do lado esquerdo (entrada da Estrada do Monte Alegre), até a parte frontal do Prédio Principal.

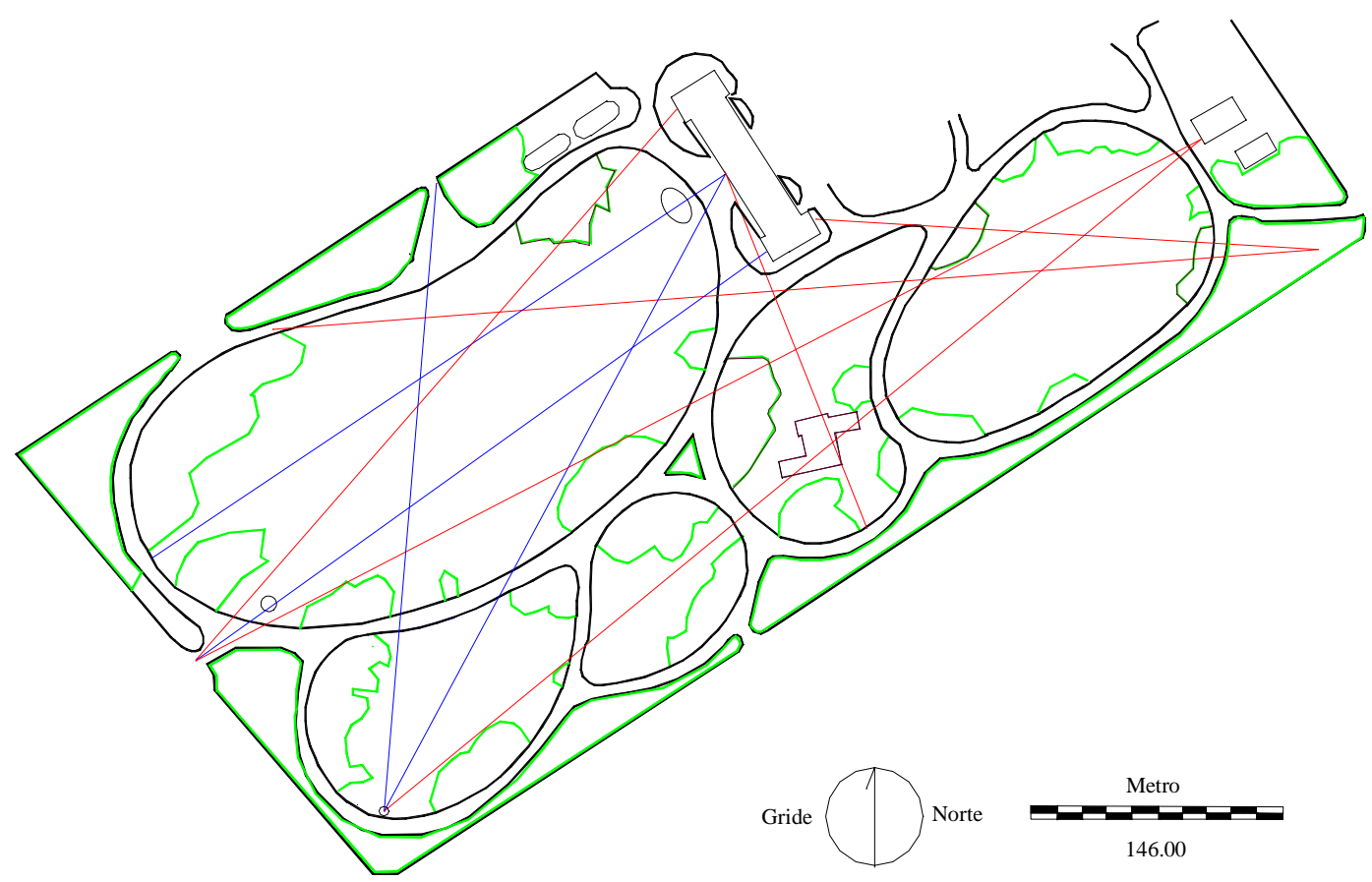

Figura 25. Mapa contendo os maciços arbóreo/arbustivos, as linhas de visada imaginárias obstruídas (linhas vermelhas), as desobstruídas (linhas azuis) e os prédios

Quanto a parte botânica do Parque, estudaram-se os levantamentos florísticos, realizados em 1965 e 1991 e confronto das espécies presentes nos mesmos. Pela não existência da planta baixa de localização física das espécies arbóreas e arbustivas por maciço, no levantamento florístico e fitossociológico de 1965, a análise teve que ser feita, considerando-se o Parque como um todo, não podendo, portanto, confrontar 
maciço a maciço, nas diferentes datas, o que permitiria levantar as mudanças ocorridas em cada um deles, fato este, que enriqueceria ainda mais este trabalho.

Os nomes das espécies encontradas no levantamento florístico de 1965, foram revisados e, atualizados quando necessário, através de consulta ao seguinte material bibliográfico: Lorenzi, 1998; Lorenzi, 1992; Lorenzi, Souza, Costa et al., 1990; Lorenzi, Costa, 1995; Barreto, 1997; Sartori, 1994; Mesquita, 1990; Tozzi, 1989; Romero, 1993; Souza, 1990; Rossi, 1987; Mabberley, 1997; Henderson, 1995 e FFESP, $1996^{7}$

Os dados obtidos nos citados levantamentos florísticos, após revisão e atualização, foram digitados no Software Access 2.0, onde se montou, para cada levantamento, uma tabela. O confronto de espécies presentes no Parque nas épocas estudadas, foi realizado através da ferramenta Consulta, do Software Access 2.0, onde também foram montadas tabelas.

Foram realizadas ainda, observações no levantamento de 1965 e em cadastro, realizado in loco, em agosto de 1998, das espécies de plantas ornamentais de pequeno porte (forrações, anuais, vivazes etc) presentes no Parque, nas referidas épocas e estes dados, foram digitados no software Excel 5.0, para Windows.

A fim de verificar se a posição do maciço em relação ao caminhamento solar, influenciou no crescimento dos maciços, realizou-se estudo, utilizando-se do IDRISI e confrontando os maciços que apresentam face voltada para o leste e portanto, ficam expostos a insolação do período matutino e os com a face voltada para o oeste, expondose portanto, à insolação do período vespertino. Foram confrontados também, seguindo a mesma metodologia, os maciços arbóreo/arbustivos com face leste e oeste, que recebem insolação direta, seja no período matutino ou vespertino, com os de face sul e norte e que portanto, não recebem insolação direta em nenhum momento do dia.

\footnotetext{
${ }^{7}$ FFESP, 1996 - Lista da Flora Fanerogâmica do Estado de São Paulo (não publicada).
} 


\section{RESULTADOS E DISCUSSÃO}

Para facilitar a discussão, os resultados deste trabalho foram divididos em dois

itens: Descaracterização da Área de Cobertura Arbórea, que discute as transformações ocorridas nos maciços arbóreo/arbustivos do Parque, no tocante ao grande crescimento em área dos maciços e sua composição florística; Linhas de Visadas Imaginárias, que discute a descaracterização do projeto original do Parque referente a obstrução de linhas de visada.

\subsection{Descaracterização da Área de Cobertura Arbórea}

\subsection{1 Área dos maciços arbóreo/arbustivos}

Através de medições realizadas nas imagens corrigidas, usando-se do software IDRISI, pôde-se observar que os maciços cresceram, em área, de forma desordenada e demasiada (Tabela 1), causando uma grande descaracterização no proposto no projeto original (Figura 26). Pode-se observar no projeto original, as ruas totalmente descobertas, enquanto nas imagens, as copas das árvores cresceram chegando, em vários locais, a encobrir totalmente as ruas, não seguindo os preceitos do Estilo Inglês, apregoados por Bellair \& Bellair (1939) na página 15 (item Localização dos maciços).

Nota-se ainda em alguns locais, por falta de manutenção adequada, a formação de maciços onde, o planejado pelo paisagista, era se ter algumas árvores isoladas. Este fato, é evidenciado no maciço de número 14, como podemos observar na Figura 27, na página 60. 
Tabela.1. Área de cada maciço arbóreo/arbustivo (em $\mathrm{m}^{2}$ ), nos anos investigados e no projeto original, calculada por meio do software IDRISI.

\begin{tabular}{|c|c|c|c|c|c|c|c|}
\hline & \multicolumn{7}{|c|}{ Resultado da medição realizada em: } \\
\hline $\begin{array}{l}\text { Maciço } \\
\text { número }\end{array}$ & $\begin{array}{c}\text { projeto original } \\
(1927)^{*}\end{array}$ & 1945 & 1962 & 1969 & 1973 & 1993 & 1995 \\
\hline 1 & ----- & 1.114 & 1.103 & 1.137 & 1.792 & 1.579 & 1.672 \\
\hline 2 & 2.329 & 2.537 & 3.177 & 3.521 & 3.912 & 4.676 & 4.493 \\
\hline 3 & 2.624 & 2.992 & 2.470 & 3.617 & 3.776 & 4.157 & 3.920 \\
\hline 4 & 4.434 & 3.187 & 4.703 & 5.488 & 4.868 & 7.996 & 8.395 \\
\hline 5 & 896 & 1.555 & 1.220 & 1.695 & 1.747 & 2.799 & 2.391 \\
\hline 6 & 321 & 514 & 709 & 430 & 528 & 1.098 & 915 \\
\hline 7 & 932 & 1.152 & 1.570 & 1.928 & 1.748 & 2.764 & 2.679 \\
\hline 8 & 256 & 337 & 750 & 752 & 1.180 & 310 & 311 \\
\hline 9 & 1.941 & 1.424 & 1.558 & 1.883 & 1.999 & 2.603 & 2.650 \\
\hline 10 & 998 & 1.335 & 1.277 & 1.466 & 1.579 & 2.374 & 2.648 \\
\hline 11 & 504 & 835 & 880 & 1.033 & 720 & 1.186 & 1.237 \\
\hline 12 & 134 & 312 & 381 & 574 & 522 & 761 & 664 \\
\hline 13 & 1.181 & 1.792 & 1.382 & 2.030 & 2.339 & 3.110 & 3.104 \\
\hline 14 & 997 & 922 & 975 & 1.118 & 1.175 & 1.894 & 1.931 \\
\hline 15 & 689 & 1.114 & 1.170 & 1.629 & 1.120 & 1.899 & 2.115 \\
\hline 16 & 3.766 & 4.129 & 4.126 & 6.601 & 6.006 & 7.110 & 7.975 \\
\hline 17 & 534 & 1.431 & 1.546 & 2.775 & 2.525 & 3.091 & 3.397 \\
\hline 18 & 1.009 & 718 & 1.357 & 2.366 & 2.277 & 3.038 & 3.185 \\
\hline 19 & 660 & 1.380 & 1.637 & 1.754 & 1.771 & 2.228 & 2.543 \\
\hline 20 & 443 & 549 & 582 & 633 & 570 & 1.028 & 1.298 \\
\hline 21 & 54 & 294 & 334 & 492 & 468 & 528 & 536 \\
\hline 22 & 93 & 479 & 487 & 759 & 614 & 781 & 918 \\
\hline 23 & 2.210 & 7.276 & 8.313 & 9.976 & 10.065 & 13.127 & 13.020 \\
\hline $24 * *$ & 1.320 & 3.598 & 3.410 & 4.557 & 3.828 & 6.323 & 5.227 \\
\hline Total & 28.641 & 40.576 & 45.114 & 58.211 & 57.127 & 76.456 & 77.221 \\
\hline
\end{tabular}

* O projeto original é datado de 1907 mas, conforme já comentado, o projetado reflete a realidade após 20 anos.

** representa a soma dos mini-maciços: a, b, c, d, e, f e g.

Analisando-se a tabela acima, pode-se observar que todos os maciços arbóreo/arbustivos cresceram em área, tomando-se por base os anos 1945 e 1995, que é a maior amplitude das medições. O maciço 8 teve comportamento inexplicável, estando 
em 1945 com $337 \mathrm{~m}^{2}$, passando a $1.180 \mathrm{~m}^{2}$ em 1973 e voltando a $311 \mathrm{~m}^{2}$ em 1995, sendo portanto, o único a decrescer.

Os maciços de números 1 e 2 existentes nas imagens (Figura 22, página 49) e não no projeto original (consultar Figura 24 na página 51), é fruto de uma mudança ocorrida em 1930, quando houve a abertura de um acesso, localizado na Alameda Principal, defronte ao Pavilhão de Zoologia, depois ocupado pelo Departamento de Economia Doméstica, dividindo o maciço de número 2 em dois maciços, ficando, portanto o projeto original sem o maciço número 1.

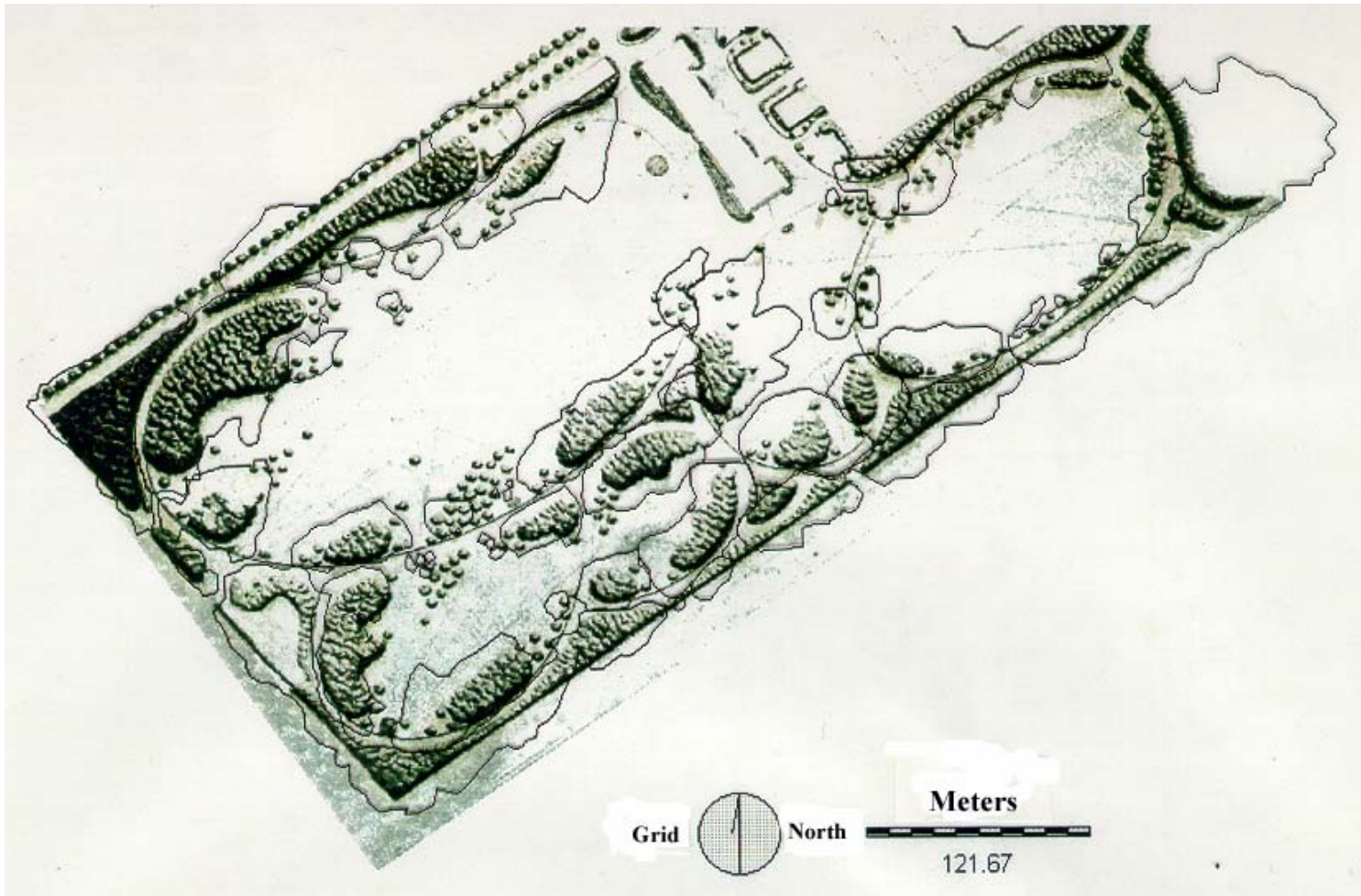

Figura 26. Planta baixa do projeto original sobreposto por layer contendo os maciços apresentados na fotografia aérea de 1995 (contornos em preto). 


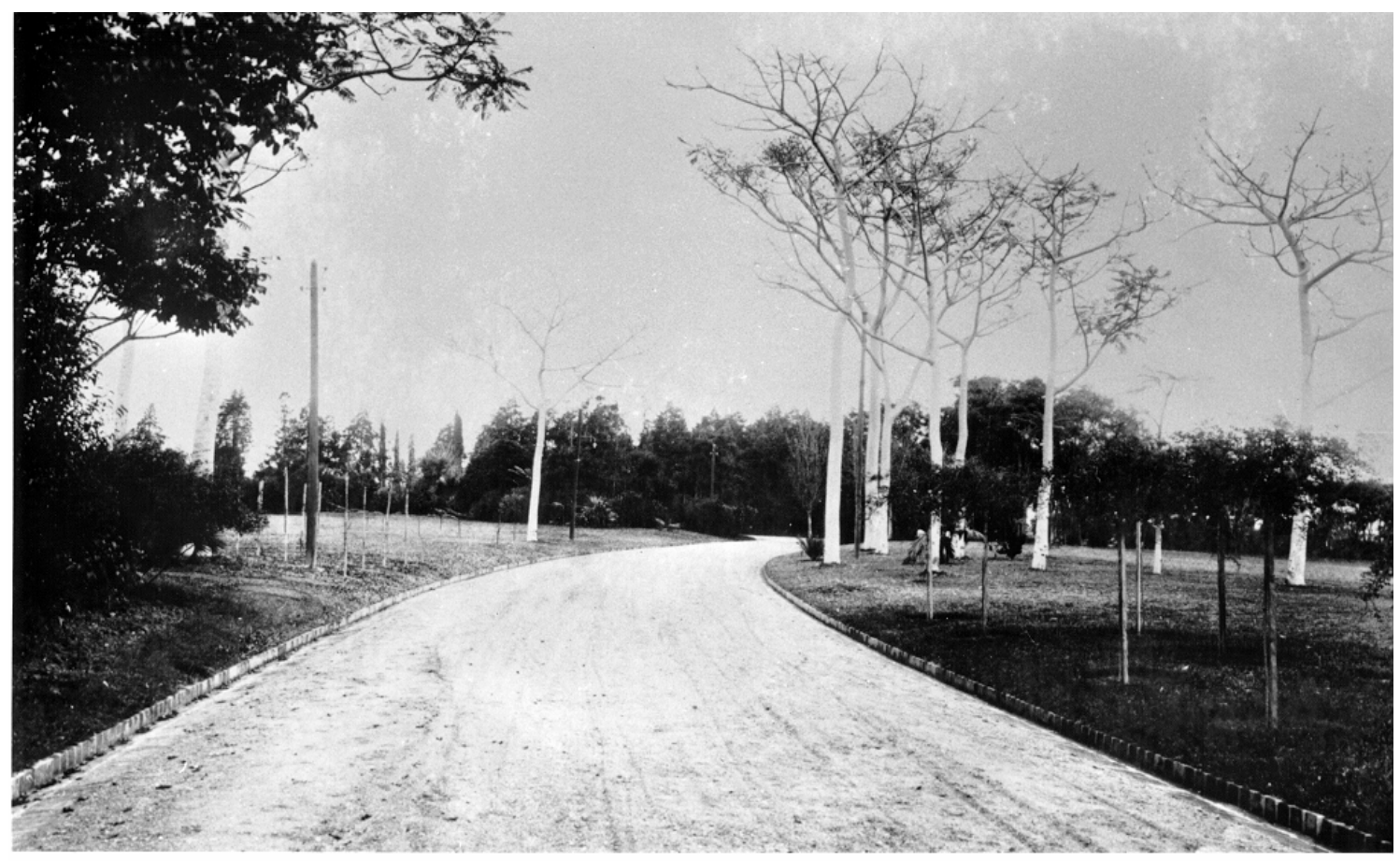

Figura 27. Fotografia do Parque da ESALQ, mostrando árvores plantadas com espaçamento maior, com o intuito de não formação de maciço, conforme o projetado por Puttemans.

A razão de crescimento, dada pela divisão da área do maciço obtida em 1995 pela área do mesmo obtida em 1945, pode ser vista na Tabela 2.

Tabela 2. Razão de Crescimento dos maciços arbóreo/arbustivos do Parque.

\begin{tabular}{cc} 
Maciço & Razão de Crescimento \\
\hline 1 & 1,50 \\
2 & 1,77 \\
3 & 1,31 \\
4 & 2,63 \\
5 & 1,54 \\
6 & 1,78 \\
7 & 2,33 \\
8 & 0,92 \\
9 & 1,86 \\
10 & 1,95 \\
11 & 1,48 \\
12 & 2,13
\end{tabular}

* representa a soma dos mini-maciços: a, b, c, d, e, f e g.

\begin{tabular}{cc} 
Maciço & Razão de Crescimento \\
\hline 13 & 1,73 \\
14 & 2,09 \\
15 & 1,90 \\
16 & 1,93 \\
17 & 2,37 \\
18 & 4,43 \\
19 & 1,84 \\
20 & 2,36 \\
21 & 1,82 \\
22 & 1,92 \\
23 & 1,79 \\
$24^{*}$ & 1,45
\end{tabular}


Quando se analisa a razão de crescimento, onde se pode ver, maciço a maciço, os que cresceram com maior intensidade, são os de número 18, 4, 17 e 20 com 4,43, 2,63, 2,37 e 2,36 respectivamente com um grande crescimento e os que tiveram menor razão de crescimento, foram os maciços 3, 24, 11 e 1, com apenas 1,31, 1,45, 1,48 e 1,50 respectivamente. O maciço de número 8, é delimitado por ruas em todo o seu perímetro, como podemos observar na Figura 22, na página 49 e portanto, formado por um número pequeno de árvores que no decorrer dos anos em estudo, apresentou grande domínio do dossel por volta dos anos 1973 que com a retirada das mesmas, diminuiu-se a área de cobertura arbórea o que pode explicar o decréscimo de sua área e a razão de crescimento de apenas 0,92. Infelizmente, devido a inexistência de mapa do levantamento florístico realizado em 1965, não se pôde saber quais a espécies formavam o maciço 8 e os que o rodeavam, para se ter maiores informações sobre o nele ocorrido.

Quanto a verificação da existência de uma relação linear entre as áreas dos maciços arbóreo/arbustivos obtidas em 1945 (eixo x) e 1995 (eixo y), verificou-se que o teste $\mathrm{F}$ para regressão linear foi altamente significativo, a 1\% de probabilidade (com F calculado $=254,77)$. A Figura 28 mostra os valores observados e a reta ajustada cuja equação é dada por $\hat{\mathrm{Y}}=202,92+1,766 x$.

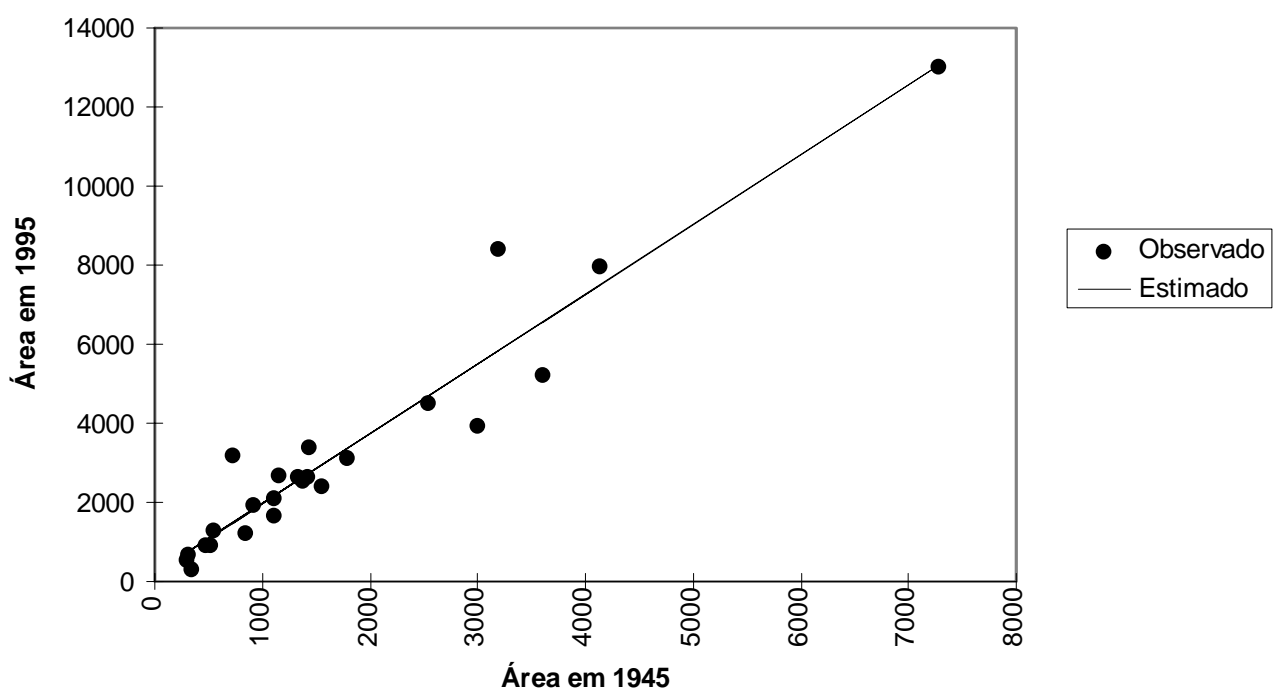

Figura 28. Gráfico da equação de regressão linear ajustada e dados observados. 
De maneira geral, analisando-se o ano de 1945, tem-se no somatório das áreas dos maciços, $40.576 \mathrm{~m}^{2}$ (ou aproximadamente 4,06 ha), que representa 27,07\% de cobertura arbórea/arbustiva, em um Parque de aproximadamente $150.000 \mathrm{~m}^{2}$ (15 ha), enquanto esse valor em 1995, sobe para $77.221 \mathrm{~m}^{2}$ (ou aproximadamente 7,72 ha), representando 51.5\% do total do Parque. Esses valores são preocupantes do ponto de vista de planejamento paisagístico pois, considerando-se o projeto original, onde essa cobertura deveria ser mantida em $28.641 \mathrm{~m}^{2}$ (ou aproximadamente 2,86 ha), representando 19\% do total do Parque é, na realidade, até o ano de 1995, o equivalente a mais da metade de sua área total (51,5\%), tendo $170 \%$ a mais de cobertura arbórea/arbustiva do que o projetado (Tabela 1 da página 58).

Quando se analisam os dados dos maciços ano a ano, observa-se que o crescimento das áreas dos maciços arbóreo/arbustivos não é constante, chegando muitas vezes, a diminuir de tamanho (Figuras 29 a 34). Isto se deve ao fato de se estar estudando maciços arbóreo/arbustivos no estágio clímax, sendo eles muito dinâmicos, onde se abrem clareiras de tempos em tempos e em lugares distintos dentro dos mesmos. Ao longo dos anos, essas clareiras são cicatrizadas por árvores que crescem neste espaço, fechando-as, processo da sucessão secundária definida por Kageyama (1986). Este efeito é mais evidenciado quando a clareira é aberta na borda do maciço, interferindo no seu perímetro. Além disso ainda se computam os erros de medição, comuns em todo processo. 


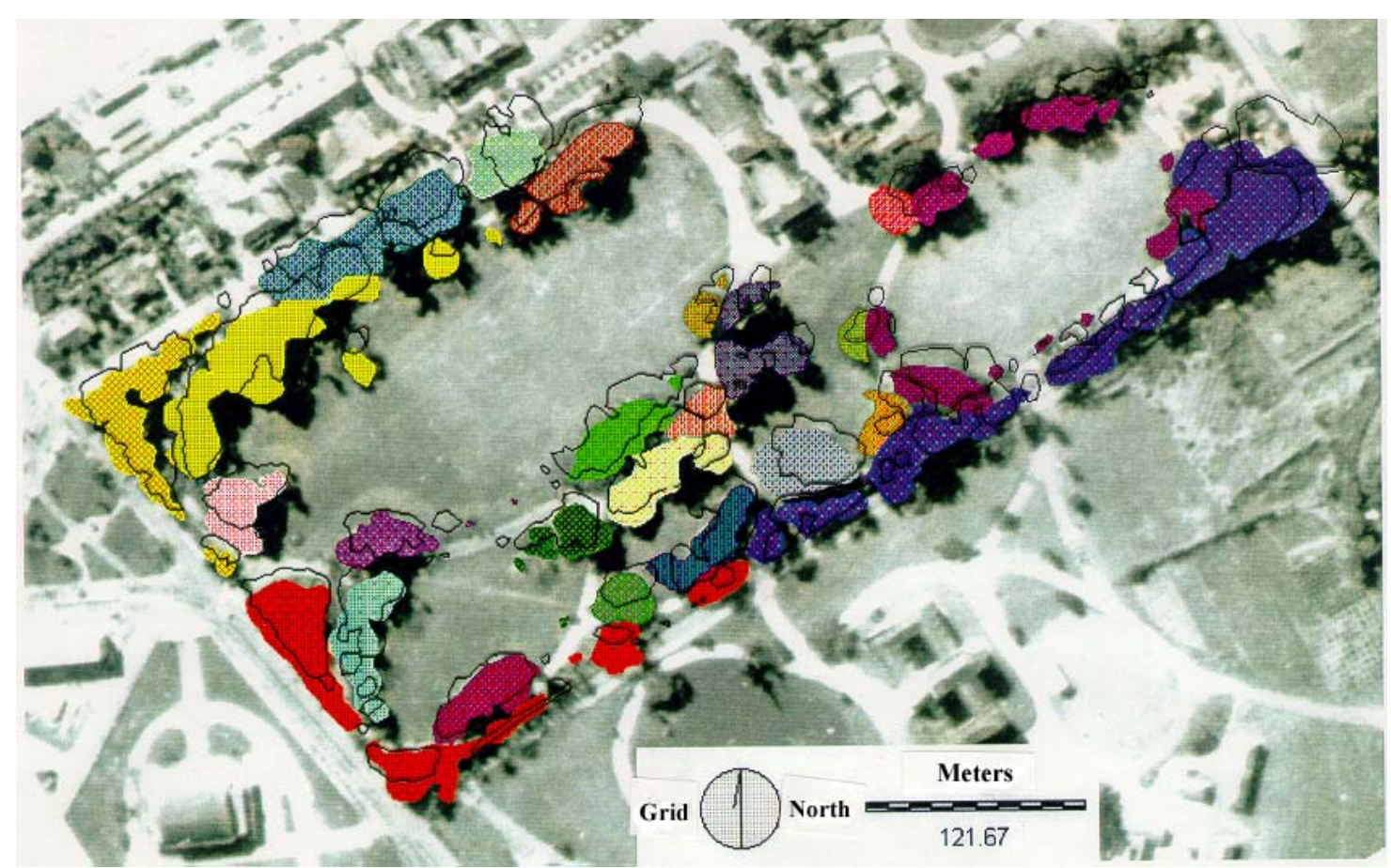

Figura 29. Fotoimagem ressaltando os maciços arbóreo/arbustivos presentes na fotografia aérea de 1962, (áreas coloridas) sobreposto por layer elaborado na digitalização da fotografia aérea de 1945 (contornos em preto).

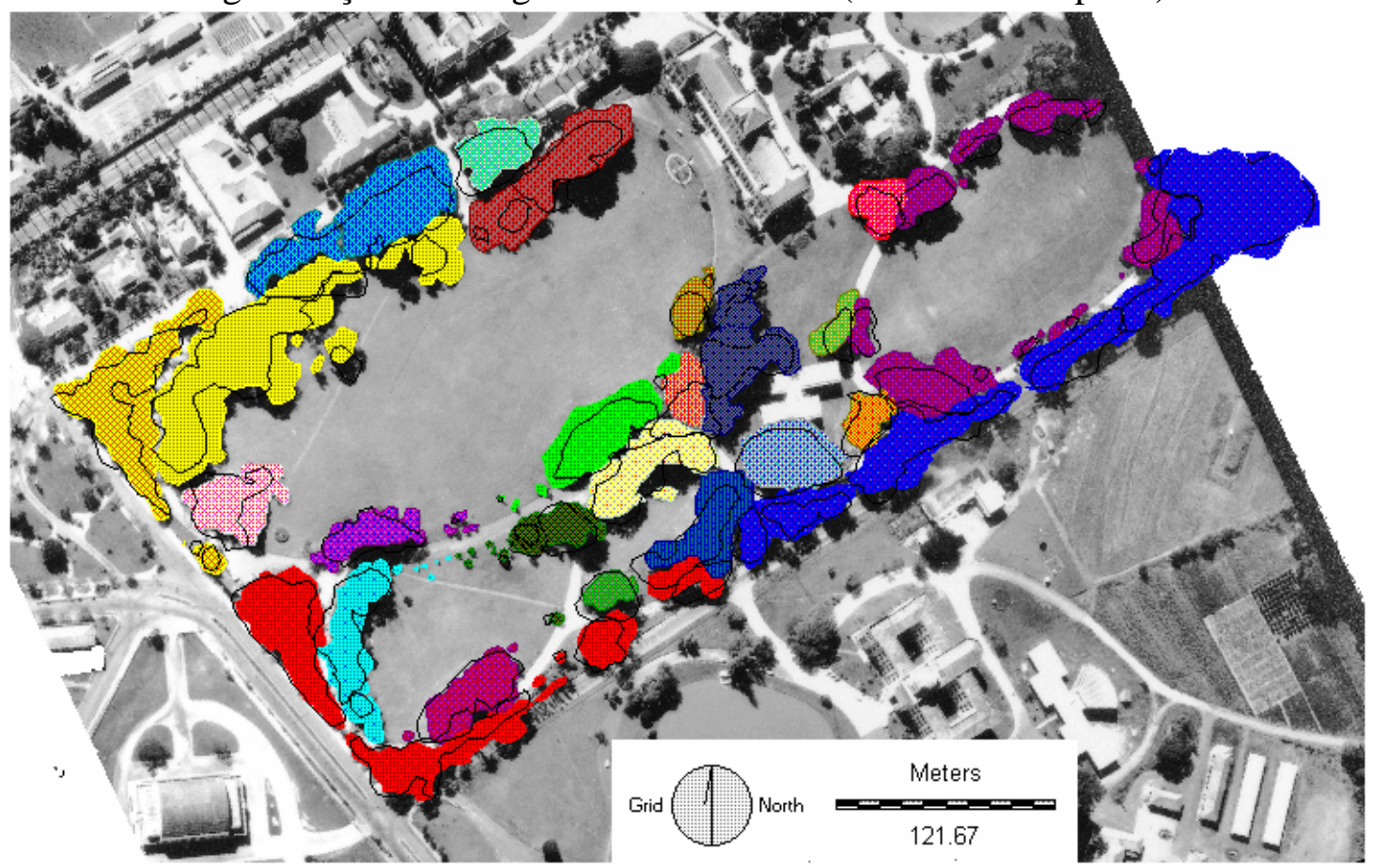

Figura 30. Fotoimagem ressaltando os maciços arbóreo/arbustivos presentes na fotografia aérea de 1969, (áreas coloridas) sobreposto por layer elaborado na digitalização da fotografia aérea de 1962 (contornos em preto). 


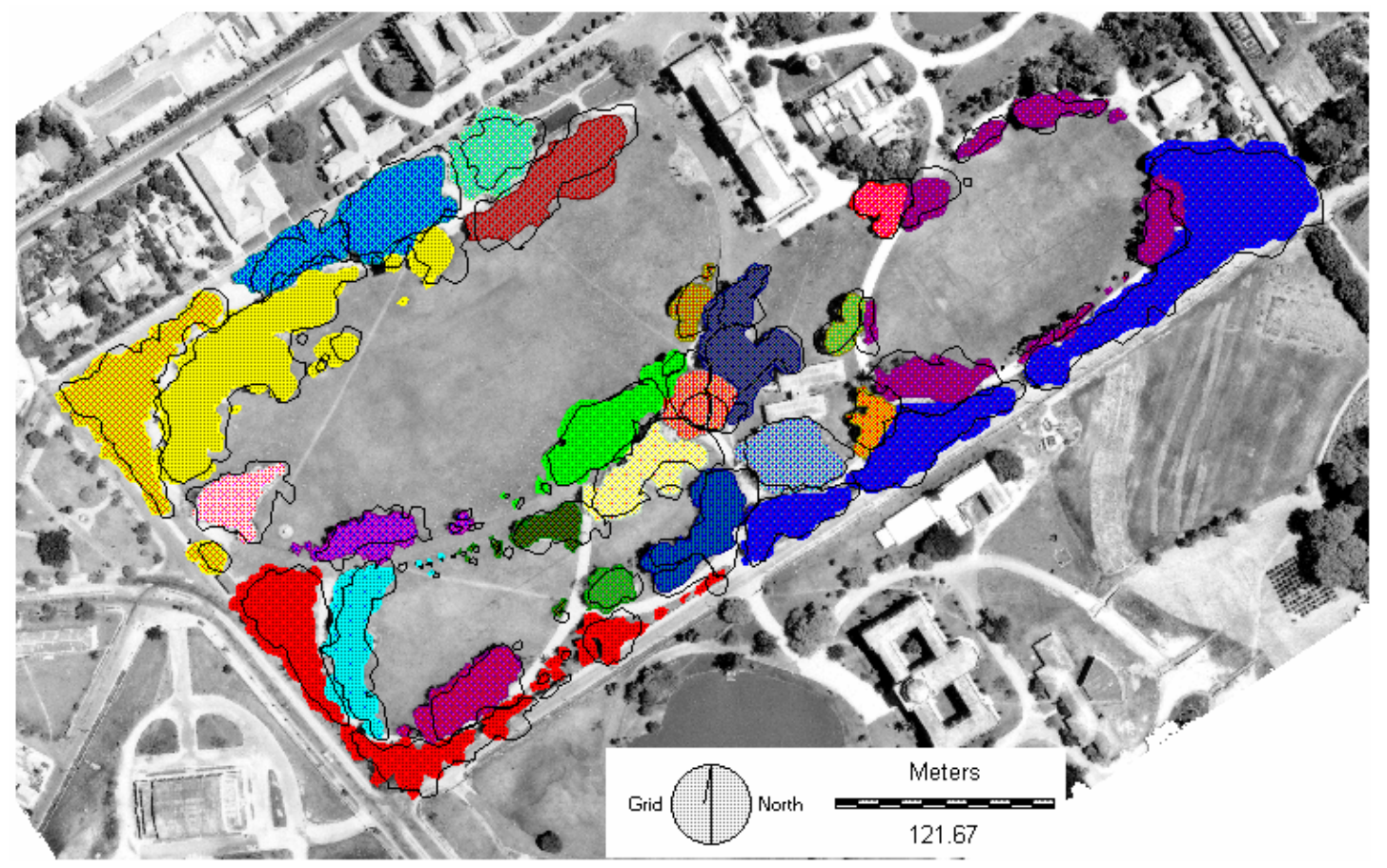

Figura 31. Fotoimagem ressaltando os maciços arbóreo/arbustivos presentes na fotografia aérea de 1973, (áreas coloridas) sobreposto por layer elaborado na digitalização da fotografia aérea de 1969 (contornos em preto).

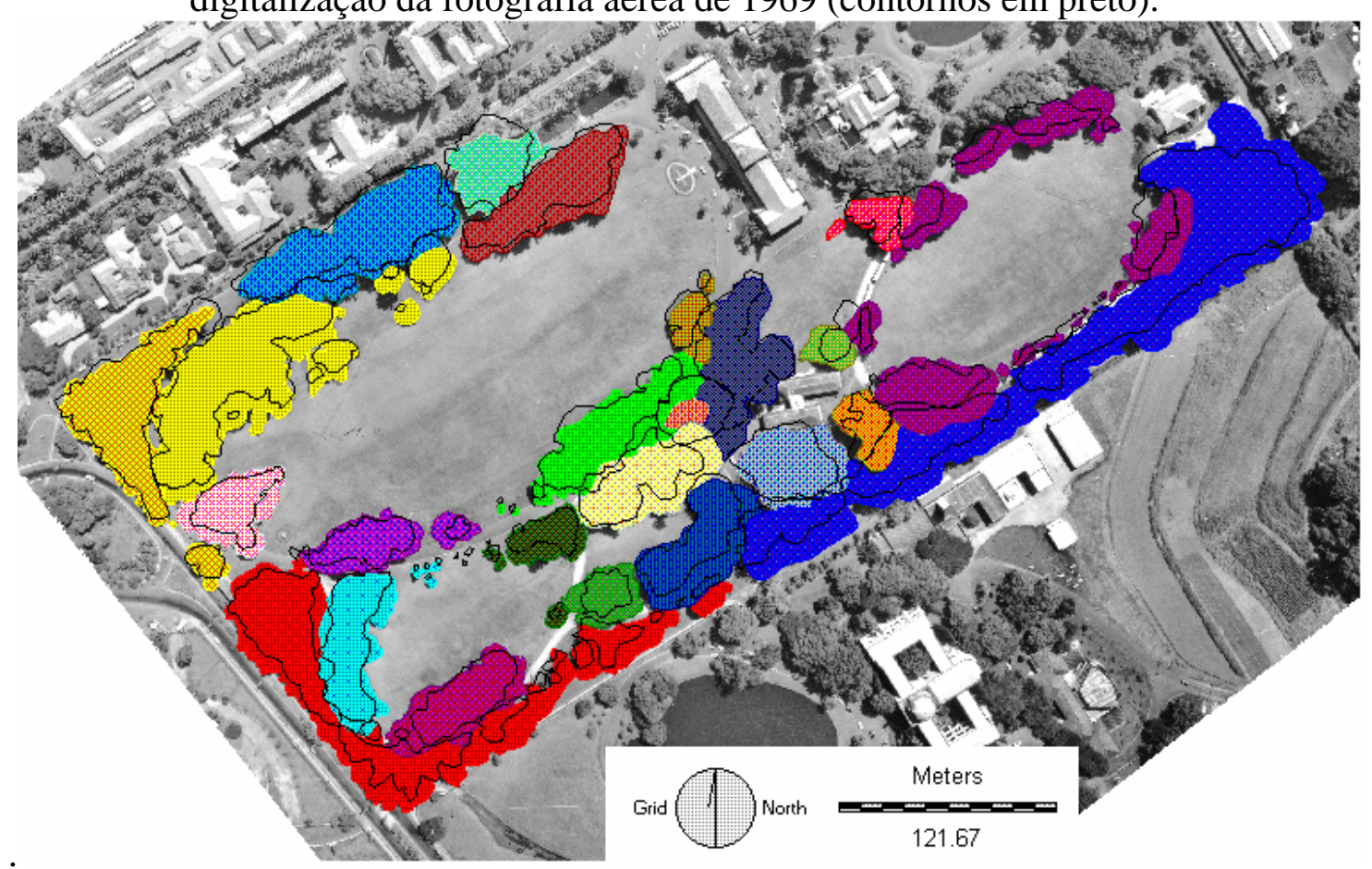

Figura 32. Fotoimagem ressaltando os maciços arbóreo/arbustivos presentes na fotografia aérea de 1993, (áreas coloridas) sobreposto por layer elaborado na digitalização da fotografia aérea de 1973 (contornos em preto). 


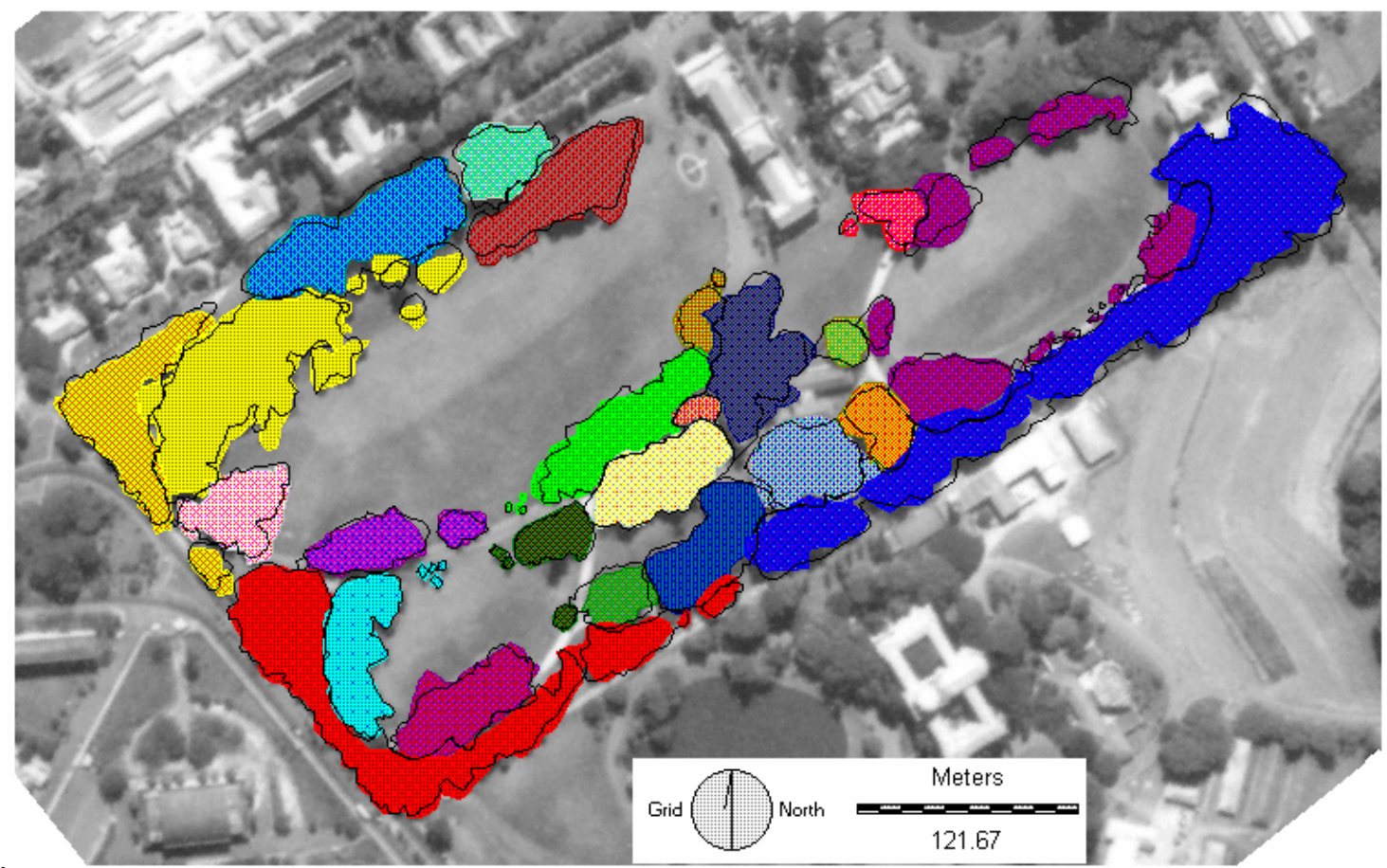

Figura 33. Fotoimagem ressaltando os maciços arbóreo/arbustivos presentes na fotografia aérea de 1995, (áreas coloridas) sobreposto por layer elaborado na digitalização da fotografia aérea de 1993 (contornos em preto).

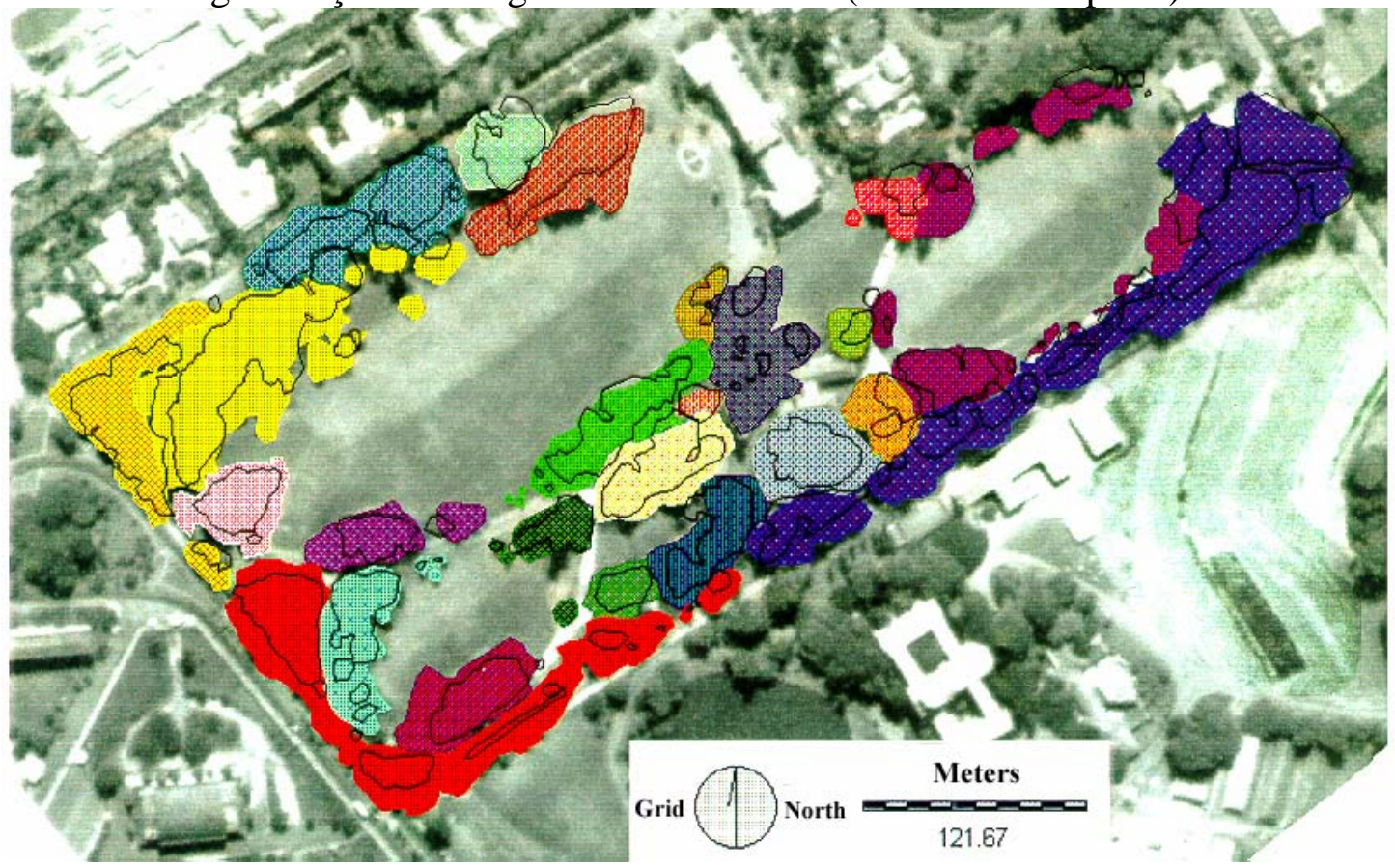

Figura 34. Fotoimagem ressaltando os maciços arbóreo/arbustivos presentes na fotografia aérea de 1995, (áreas coloridas) sobreposto por layer elaborado na digitalização da fotografia aérea de 1945 (contornos em preto), sendo, portanto a maior amplitude, em anos, estudada. 
Outro fator preocupante, são as mudas de árvores plantadas no perímetro dos maciços. Como se observa na Figura 35, onde existe uma muda plantada em comemoração a uma turma de formandos, no perímetro do maciço número 7. Essa muda de árvore quando adulta, formará copa sobre o gramado, sombreando-o e aumentando a área do maciço. Ao longo dos anos, devido ao sombreamento, a grama poderá morrer, formando no local, serrapilheira e dando oportunidade a outras sementes germinarem, aumentando ainda mais a área do maciço, fato este, que pode-se observar no maciço 11, onde uma outra muda está crescendo no perímetro do maciço, em local sombreado (Figura 36).

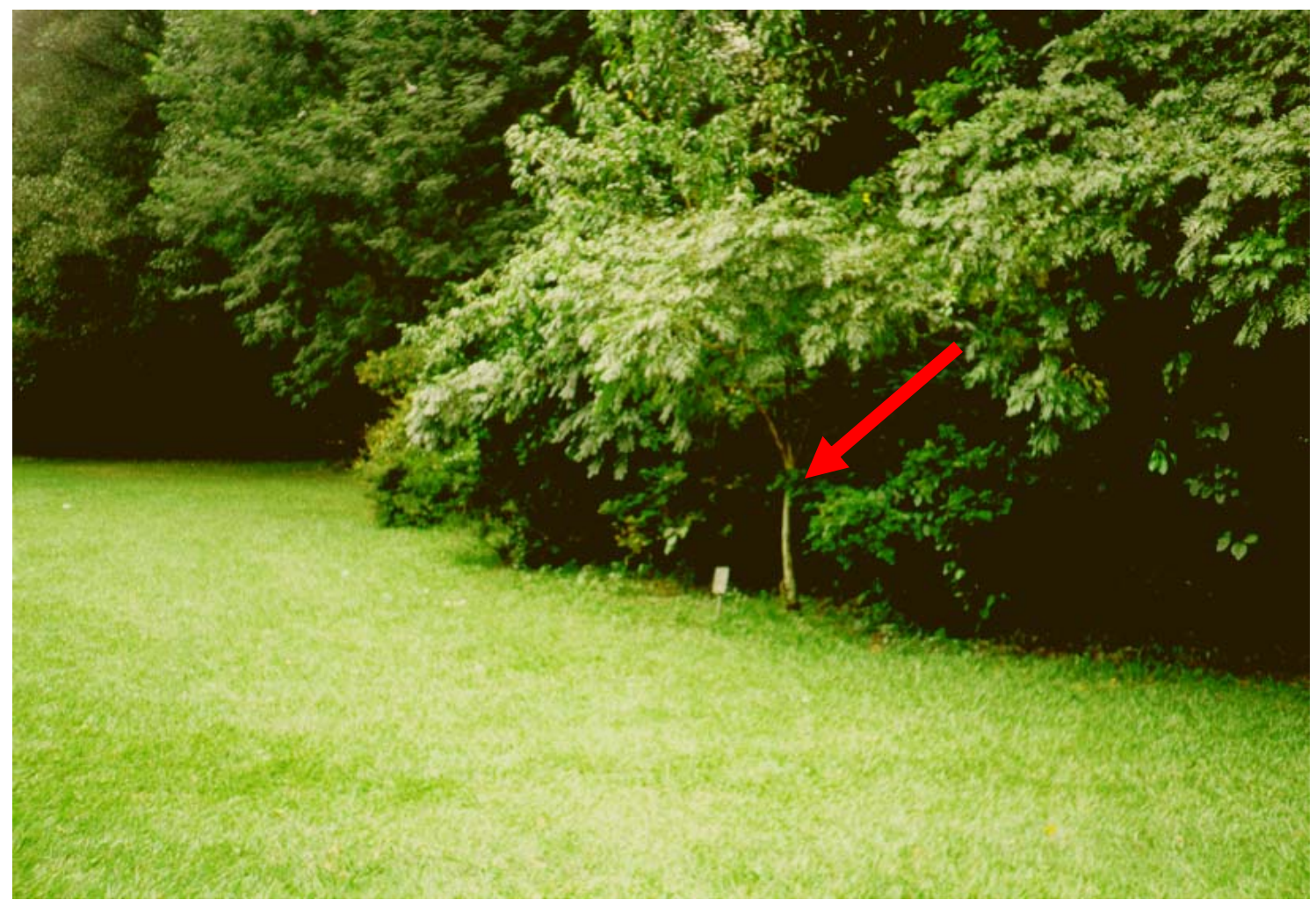

Figura 35. Fotografia ilustrando uma muda de árvore que foi plantada no perímetro do maciço número 7. 


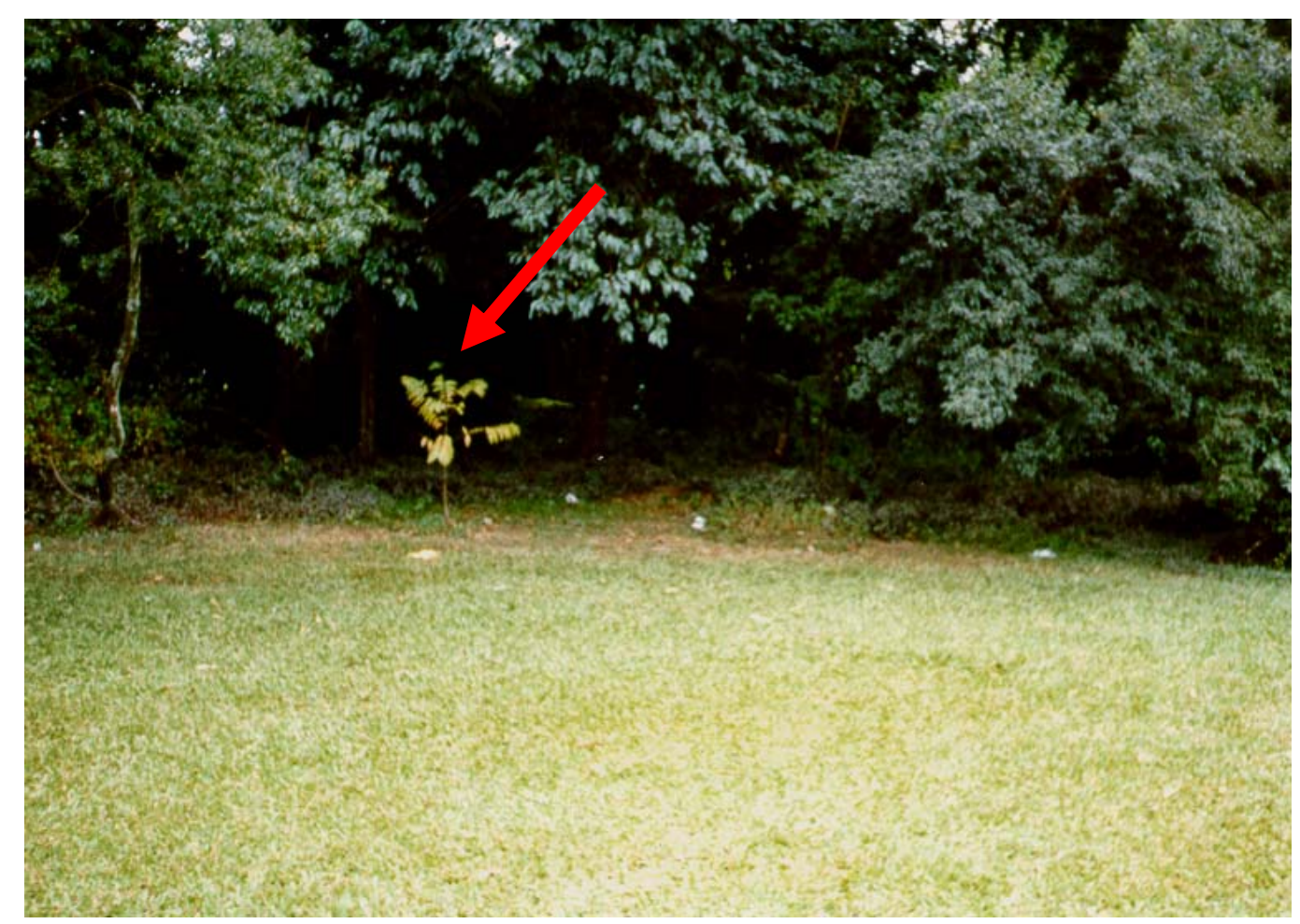

Figura 36. Fotografia ilustrando uma muda de árvore que nasceu espontaneamente sob área sombreada no perímetro do maciço número 11.

Quanto a verificação da influência do posicionamento do maciço, com face maior leste e portanto, recebendo a insolação vespertina ou com face oeste e portanto recebendo insolação matutina, relacionado ao crescimento dos mesmos, o resultado não apontou significância, a 5\% de probabilidade, porém os maciços que receberam a insolação vespertina, tiveram maior crescimento. Para os com face leste ou oeste, que recebem insolação direta, seja no período matutino ou vespertino, confrontados com os de face sul e norte e que portanto, não recebem insolação direta em nenhum momento do dia, os resultados também foram não significativos a 5\% de probabilidade, porém houve maior crescimento dos maciços que receberam insolação direta.

\subsubsection{Botânica dos maciços}

Do ponto de vista botânico, analisando-se as Tabelas 3 e 4, que contém os indivíduos arbóreo-arbustivos do maciço 1 ao 22, lembrando-se que, o levantamento de 1991, está, por hora, incompleto (faltando a catalogação dos indivíduos dos maciços 23 
e 24), nota-se que houve inúmeras mudanças, tanto em quantidade de indivíduos arbóreos, quanto em número de espécies presentes nesta parte do Parque em estudo. Pode-se notar no levantamento florístico realizado em 1965, por Fadigas, que a área em estudo, era formado por 444 indivíduos arbóreos e em 1991, através de novo levantamento (realizado por Ricardo R. Rodrigues), passa a ser composto por 2.904 indivíduos, tendo portanto, seis vezes mais árvores que no primeiro levantamento.

Quanto às espécies vegetais, houve diminuição no número de espécies arbóreas de um levantamento para o outro. Em 1965, a parte do Parque estudado, era composto por 241 espécies, estando em 1991, formado por 215 espécies. Esses dados se mostram muito preocupantes, notando-se ainda a presença de reboleiras em alguns maciços, ocorrendo grande domínio de algumas espécies sobre outras. No período estudado, 154 espécies, foram extintas da área em estudo (Tabela 5) e outras 124 foram incorporadas, no mesmo período (Tabela 6). Um total de apenas 90 árvores, aparecem nos dois levantamentos (Tabela 7).

Tabela 3. - Lista do levantamento florístico, realizado em 1965, das espécies vegetais arbóreas e arbustivas encontradas em parte do Parque (maciço 1 ao 22) e o número de exemplares de cada espécie.

Nome Botânico

Acacia cultriformis

Acalypha wilkesiana

Adenanthera pavonina

Agathis australis

Alchornea iricurama

Anadenanthera falcata

Araucaria columnaris

Arenga pinnata

Artocarpus heterophyllus

Arundo donax

Attalea phalerata

Bauhinia longipetala

Bauhinia monandra

Brosimum rubescens

Cabralea eichleriana

Cabralea laevis

Caesalpinia ferrea

Caesalpinia gardneriana

Caesalpinia peltophoroides
Número de Ind.

1
1
1
1
1
1
1
1
1
1
1
1
1
1
1
1
1
1
1

Nome Botânico

Número de Ind.

Caesalpinia tinctoria 1

Carissa arduina $\quad 1$

Cariniana estrellensis $\quad 1$

Cariniana legalis $\quad 1$

Carludovica palmata $\quad 1$

Caryota mitis

Casearia sylvestris

Cassia grandis

Cassia macranthera

Ceiba erianthus

Ceiba pentandra

Centrolobium robustum

Chrysopsis virginiana

Coccoloba uvifera

Cocus nucifera

Commelina rufipes

Couroupita guianensis

Crescentia cujete

Croton floribundus

1
1
1
1
1
1
1
1
1
1
1
1
1
1
1
1
1
1
1


Tabela 3. - Lista do levantamento florístico, realizado em 1965, das espécies vegetais arbóreas e arbustivas encontradas em parte do Parque (maciço 1 ao 22) e o número de exemplares de cada espécie.

\begin{tabular}{|c|c|c|c|}
\hline Nome Botânico & Número de Ind. & Nome Botânico & Número \\
\hline Cunninghamia lanceolata & 1 & Malvaviscus arboreus & 1 \\
\hline Cupressus funebris & 1 & Melaleuca leucadendra & 1 \\
\hline Cupressus macrocarpa & 1 & Michelia champaca & 1 \\
\hline Cycas revoluta & 1 & Mimosa verrucosa & 1 \\
\hline Dalbergia nigra & 1 & Mimosa elengi & \\
\hline Dichorisandra thyrsiflora & 1 & Miroxylon toluiferum & \\
\hline Dillenia indica & 1 & Moquilea tomentosa & \\
\hline Dypsis lutescens & 1 & Myrcia sphaerocarpa & \\
\hline Entorolobium timbouva & 1 & Myrciaria cauliflora & \\
\hline Ervatamia coronaria & 1 & Norantea brasiliensis & \\
\hline Erythrina corallodendrum & 1 & Patagonula americana & \\
\hline Erythroxylum spruceanum & 1 & Paulownia taiwaniana & \\
\hline Eugenia brasiliensis & 1 & Phoenix canariensisa & \\
\hline Eugenia selloi & 1 & Phoenix paludosa & \\
\hline Ficus bengalensis & 1 & Phoenix reclinata & \\
\hline Ficus benjamina & 1 & Phoenix rupicula & \\
\hline Ficus doliaria & 1 & Pimenta racemosa & \\
\hline Ficus elastica & 1 & Pinus michoacana & 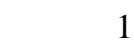 \\
\hline Ficus lyrata & 1 & Piper ceanothifolium & \\
\hline Ficus pumila & 1 & Pithecolobium diversifolium & \\
\hline Ficus religiosa & 1 & Polyscias filicifolia & \\
\hline Ficus roxburghii & 1 & Pontederia cordata & \\
\hline Firmiana simplex & 1 & Psidium guayava & \\
\hline Gallezia integrifolia & 1 & Pterodon emarginatus & \\
\hline Ginkgo biloba & 1 & Pterogyne nitens & 1 \\
\hline Guarea salgadensis & 1 & Ptychosperma elegans & \\
\hline Hevea brasiliensis & 1 & Punica granatum & \\
\hline Hibiscus schizopetalus & 1 & Ravenala madascariensis & \\
\hline Howeia kirsteniana & 1 & Rhapis excelsa & \\
\hline Hura crepitans & 1 & Rhodotypos kerrioides & \\
\hline Ixora acuminata & 1 & Schinus terebenthifolius & 1 \\
\hline Ixora coccinea & 1 & Schotia brachypetala & \\
\hline Jacaranda cuspidifolia & 1 & Serjania orbicularis & \\
\hline Jaracatia dodecaphylla & 1 & Severinia buxifolia & \\
\hline Lantana brasiliensis & 1 & Spondias tuberosa & 1 \\
\hline Ligustrum japonicum & 1 & Syagrus romanzoffianum & \\
\hline Lippia cycioides & 1 & Tabebuia avellanede & \\
\hline Lippia lycioides & 1 & Tabebuia roseo alba & \\
\hline Livistona australis & 1 & Thuja occidentalis & 1 \\
\hline Livistona rotundifolia & 1 & Thuja orientalis & \\
\hline Lonicera maakii & 1 & Tibouchina stenocarpa & \\
\hline Lonicera ruprechtiana & 1 & Trichilea catigua & \\
\hline Lophantera lactescens & 1 & Trichllia claussenii & \\
\hline Luhea divaricata & 1 & Typha latifolia & \\
\hline Macfadyena unguis-cati & 1 & Vangueria madagascariensis & \\
\hline Machaerium milleflorum & 1 & Vernonia polyanthes & \\
\hline Malpighia coccinea & 1 & Yucca schottii & \\
\hline
\end{tabular}


Tabela 3. - Lista do levantamento florístico, realizado em 1965, das espécies vegetais arbóreas e arbustivas encontradas em parte do Parque (maciço 1 ao 22) e o número de exemplares de cada espécie.

\begin{tabular}{|c|c|}
\hline \multirow{2}{*}{\multicolumn{2}{|c|}{ Nome Botânico }} \\
\hline & \\
\hline Zanthoxylum latespinosum & 1 \\
\hline Zizyphus joazeiro & 1 \\
\hline Acacia farnesiana & 2 \\
\hline Albizzia lebbeck & 2 \\
\hline Aleurites mollucana & 2 \\
\hline Anadenanthera macrocarpa & 2 \\
\hline Araucaria angustifolia & 2 \\
\hline Archontophoenix alexandrae & 2 \\
\hline Astronium graveolens & 2 \\
\hline Bauhinia variegata & 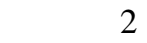 \\
\hline Brunfelsia uniflora & 2 \\
\hline Caesalpinia pulcherrima & 2 \\
\hline Camellia japonica & 2 \\
\hline Caryota urens & 2 \\
\hline Chlorophora tinctoria & 2 \\
\hline Chorizia speciosa & 2 \\
\hline Chrysophyllum ebenaceum & 2 \\
\hline Cryptomeria japonica & 2 \\
\hline Dalbergia variabilis & 2 \\
\hline Enterolobium monjollo & 2 \\
\hline Eriobotrya japonica & 2 \\
\hline Erythrina mulungu & 2 \\
\hline Erythrina speciosa & 2 \\
\hline Erythroxylum parvistipulatum & 2 \\
\hline Euphorbia milii & 2 \\
\hline Garcinia cochinchinensis & 2 \\
\hline Gardenia thunbergia & 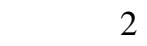 \\
\hline Grevillea banksii & 2 \\
\hline Grevillea robusta & 2 \\
\hline Hymenae stilbocarpa & 2 \\
\hline Ixora chinensis & 2 \\
\hline Lafoensia glyptocarpa & 2 \\
\hline Lafoensia pacari & 2 \\
\hline Lecythis pisonis & 2 \\
\hline Ligustrum lucidum & 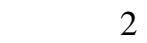 \\
\hline Livistona saribus & 2 \\
\hline Lonchocarpus sericeus & 2 \\
\hline Machaerium villosum & 2 \\
\hline Myracrodruon urundeuva & 2 \\
\hline Myroxylon peruiferum & 2 \\
\hline Myrtus rubra & 2 \\
\hline Ocotea odorifera & 2 \\
\hline Pachystroma iliciflorum & 2 \\
\hline Paulinia elegans & 2 \\
\hline Pittosporum undu & \\
\hline
\end{tabular}

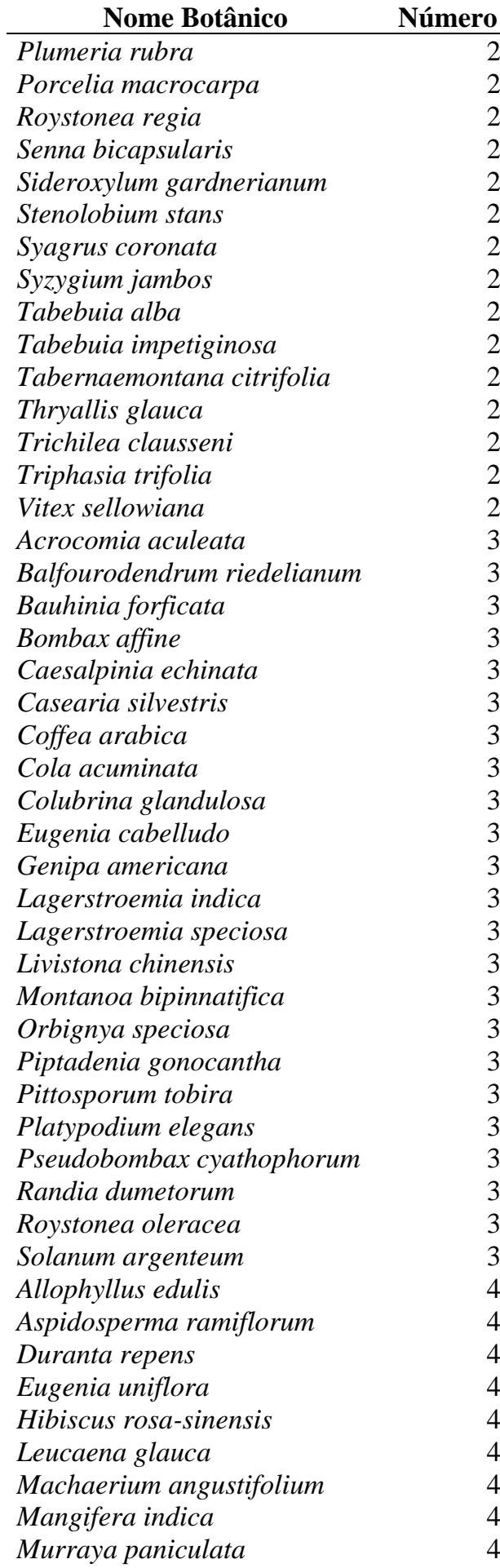

de Ind.

(2)

2

2

2

2


Tabela 3. - Lista do levantamento florístico, realizado em 1965, das espécies vegetais arbóreas e arbustivas encontradas em parte do Parque (maciço 1 ao 22) e o número de exemplares de cada espécie.

\begin{tabular}{lc}
\multicolumn{1}{c}{ Nome Botânico } & Número de Ind. \\
\hline Phoenix canariensis & 4 \\
Schyzolobium parahybum & 4 \\
Syzygium cuminii & 4 \\
Zanthoxylum rhoifolium & 4 \\
Buxus sempervirens & 5 \\
Pereskia grandifolia & 5 \\
Tabebuia flavescens & 5 \\
Tipuana speciosa & 5
\end{tabular}

\begin{tabular}{lc}
\multicolumn{1}{c}{ Nome Botânico } & Número de Ind. \\
\hline Bougainvillea glabra & 6 \\
Delonix regia & 6 \\
Holocallix balansae & 6 \\
Joannesia princeps & 6 \\
Spiraea arguta & 6 \\
Euphorbia pulcherrima & 7 \\
Nectandra venulosa & 7 \\
Bougainvillea spectabilis & 8
\end{tabular}

Tabela 4. Lista do levantamento florístico, realizado em 1991, das espécies vegetais arbóreas e arbustivas encontradas em parte do Parque (maciço 1 ao 22) e o número de exemplares de cada espécie.

\begin{tabular}{lc}
\multicolumn{1}{c}{ Nome Botânico } & Número de Ind. \\
\hline Aloysia virgata & 1 \\
Aspidosperma olivaceum & 1 \\
Bombacopsis stenopetala & 1 \\
Caesalpinea pulcherrima & 1 \\
Caesalpinia echinata & 1 \\
Campomanesia guazumaefolia & 1 \\
Caryota mitis & 1 \\
Cassia ferruginea & 1 \\
Cassia macranthera & 1 \\
Ceiba erianthus & 1 \\
Coccoloba uvifera & 1 \\
Cocus nucifera & 1 \\
Cola acuminata & 1 \\
Colubrina glandulosa & 1 \\
Coutarea hexandra & 1 \\
Cycas circinalis & 1 \\
Diospyros inconstans & 1 \\
Dracaena fragrans & 1 \\
Elaeis guineensis & 1 \\
Esembeckia febrifuga & 1 \\
Eugenia brasiliensis & 1 \\
Euphorbia hermentiana & 1 \\
Ficus elastica & 1 \\
Ficus lyrata & 1 \\
Ficus religiosa & 1 \\
Galipea multiflora & 1 \\
Garcinia cochinchinensis & 1 \\
Gochnatia velutina & 1 \\
Guatteria sp & 1 \\
Hura crepitans & 1 \\
Jacaranda mimosaefolia & 1 \\
Jacaratia spinosa &
\end{tabular}

\begin{tabular}{lc}
\multicolumn{1}{c}{ Nome Botânico } & Número de Ind. \\
\hline Ligustrum lucidum & 1 \\
Livistona chinensis & 1 \\
Machaerium angustifolium & 1 \\
Manihot grahamii & 1 \\
Moquilea tomentosa & 1 \\
Myrcia rostrata & 1 \\
Pachystroma iliciflorum & 1 \\
Paxiuba syagrus & 1 \\
Peltophorum dubium & 1 \\
Pittosporum tobira & 1 \\
Porcelia macrocarpa & 1 \\
Pterocarpus violaceus & 1 \\
Roystonea regia & 1 \\
Securinega guaraiuva & 1 \\
Solanum argenteum & 1 \\
Solanum erianthum & 1 \\
Solanum swartzianum & 1 \\
Spondias lutea & 1 \\
Spondias mombim & 1 \\
Sterculia chicha & 1 \\
Tabebuia caraiba & 1 \\
Tapirira marchiandii & 1 \\
Trichilia pallida & 1 \\
Triplaris americana & 1 \\
Zanthoxylum chiloperone & 1 \\
Alchornea iricurama & 2 \\
Caesalpinia gardneriana & 2 \\
Caesalpinia leyostachya & 2 \\
Calyptrantes concinna & 2 \\
Caryota urens & 2 \\
Cedrella odorata & 2 \\
Chrysophyllum ebenaceum & 2 \\
&
\end{tabular}


Tabela 4. Lista do levantamento florístico, realizado em 1991, das espécies vegetais arbóreas e arbustivas encontradas em parte do Parque (maciço 1 ao 22) e o número de exemplares de cada espécie.

Nome Botânico

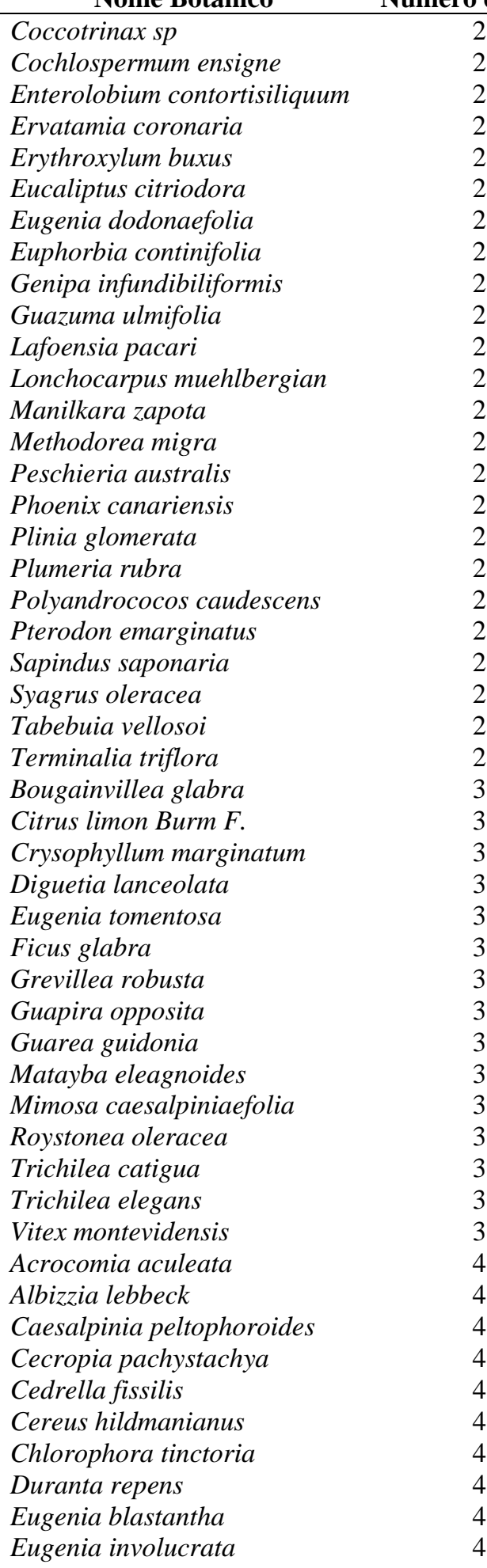

Nome Botânico

Hymenaea stilbocarpa

Leucaena leucocephala

Pachystroma longifolium

Psidium cattleianum

Psidium guayava

Seguieria langsdorffii

Thevetia peruviana

Triplaris brasiliensis

Aspidosperma pyrifolium

Attalea phalerata

Calycophyllum sprunceanum

Eugenia pluriflora

Ficus guaranitica

Centrolobium robustum

Chrysophylum marginatum

Erythroxylum deciduum

Gochnatia polymorpha

Pisonia ambigua

Pseudobombax grandiflorum

Tabebuia impetiginosa

Zanthoxylum hiemale

Aleurites mollucana

Bauhinia blackeana

Bauhinia forficata

Caesalpinia ferrea

Eugenia jambos

Randia armata

Syzygium cuminii

Myrcia cauliflora

Myrciaria cauliflora

Zanthoxylum rhoifolium

Blepharocalyx salicifolius

Bombacopsis glabra

Miroxylon peruiferum

Chamaecyparis funebris

Samanea saman

Chrysophyllum gonocarpum

Erythrina vellutina

Eugenia uniflora

Lecythis pisonis

Eugenia moraviana

Myrcia ramulosa

Taxodium disthicum

Gallesia integrifolia

Tabebuia crysotricha

Entorolobium timbouva

Lagerstroemia speciosa

Sebastianiana serrata

Anadenanthera peregrina
Número de Ind.

4

4

4

4

4

4

4

4

5

5

5

5

5

6

6

6

6

6

6

6

6

7

7

7

7

7

7

7

8

8

8

9

9

9

10

10

11

11

11

11

12

12

12

13

13

14

14

14

15 
Tabela 4. Lista do levantamento florístico, realizado em 1991, das espécies vegetais arbóreas e arbustivas encontradas em parte do Parque (maciço 1 ao 22) e o número de exemplares de cada espécie.

\begin{tabular}{lc}
\multicolumn{1}{c}{ Nome Botânico } & Número de Ind. \\
\hline Cariniana strellensis & 15 \\
Genipa americana & 15 \\
Phoenix reclinata & 15 \\
Hymenae stilbocarpa & 17 \\
Cariniana legalis & 18 \\
Luehea divaricata & 18 \\
Machaerium stipitatum & 18 \\
Nectandra megapotamica & 18 \\
Pereskia grandifolia & 18 \\
Schyzolobium parahybum & 18 \\
Myracrodruon urundeuva & 20 \\
Murraya paniculata & 21 \\
Tabebuia heptaphylla & 21 \\
Peschiera fuchsiaefolia & 23 \\
Trichllia claussenii & 25 \\
Cereus peruviana & 26 \\
Erythroxylum ambiggum & 26 \\
Machaerium nictitans & 26 \\
Mangifera indica & 27 \\
Copaifera langsdorfii & 28 \\
Myroxylon peruiferum & 29 \\
Aspidosperma cylindrocarpum & 30 \\
Patagonula americana & 32 \\
Bougainvillea spectabilis & 33 \\
Delonix regia & 33
\end{tabular}

\begin{tabular}{lc}
\multicolumn{1}{c}{ Nome Botânico } & Número de Ind. \\
\hline Platypodium elegans & 33 \\
Piptadenia gonoacantha & 34 \\
Zizyphus joazeiro & 34 \\
Lafoensia glyptocarpa & 35 \\
Machaerium aculeatum & 37 \\
Tipuana tipu & 37 \\
Tabebuia serratiflora & 39 \\
Anadenanthera colubrina & 40 \\
Chorizia speciosa & 40 \\
Aspidosperma polyneron & 41 \\
Astronium graveolens & 43 \\
Balfourodendrum riedelianum & 57 \\
Anadenanthera macrocarpa & 60 \\
Centrolobium tomentosum & 60 \\
Joannesia princeps & 63 \\
Parapiptadenia rigida & 64 \\
Trichilea clausseni & 66 \\
Esenbeckia leiocarpa & 70 \\
Myrcia laruotteana & 82 \\
Syagrus romanzoffiana & 87 \\
Allophyllus edulis & 95 \\
Machaerium villosum & 99 \\
Holocaliyx balansae & 107 \\
Aspidosperma ramiflorum & 125 \\
Casearia silvestris & 129 \\
Rhamnidium elaeocarpum & 176
\end{tabular}

Tabela 5. Lista das espécies arbóreas e arbustivas que foram extintas do Parque no período estudado.

\section{Nome Botânico}

Acacia cultriformis

Acacia farnesiana

Acalypha wilkesiana

Adenanthera pavonina

Agathis australis

Anadenanthera falcata

Araucaria angustifolia

Araucaria columnaris

Archontophoenix alexandrae

Arenga pinnata

Artocarpus heterophyllus

Arundo donax

Bauhinia longipetala

Bauhinia monandra

Bauhinia variegata

Bombax affine

\section{Nome Botânico}

Brosimum rubescens

Brunfelsia uniflora

Buxus sempervirens

Cabralea eichleriana

Cabralea laevis

Caesalpinia tinctoria

Camellia japonica

Carissa arduina

Carludovica palmata

Casearia sylvestris

Cassia grandis

Ceiba pentandra

Chrysopsis virginiana

Commelina rufipes

Couroupita guyanensis

Crescentia cujete 
Tabela 5. Lista das espécies arbóreas e arbustivas que foram extintas do Parque no período estudado.

Nome Botânico

Croton floribundus

Cryptomeria japonica

Cunninghamia lanceolata

Cupressus funebris

Cupressus macrocarpa

Cycas revoluta

Dalbergia nigra

Dalbergia variabilis

Dichorisandra thyrsiflora

Dillenia indica

Dypsis lutescens

Enterolobium monjollo

Eriobotrya japonica

Erythrina corallodendrum

Erythrina mulungu

Erythrina speciosa

Erythroxylum parvistipulatum

Erythroxylum spruceanum

Eugenia cabelludo

Eugenia selloi

Euphorbia milii

Euphorbia pulcherrima

Ficus bengalensis

Ficus benjamina

Ficus doliaria

Ficus pumila

Ficus roxburghii

Firmiana simplex

Gardenia thunbergia

Ginkgo biloba

Grevillea banksii

Guarea salgadensis

Hevea brasiliensis

Hibiscus rosa-sinensis

Hibiscus schizopetalus

Howeia kirsteniana

Ixora acuminata

Ixora coccinea

Jacaranda cuspidifolia

Jaracatia dodecaphylla

Lagerstroemia indica

Lantana brasliensis

Leucaena glauca

Ligustrum japonicum

Lippia cycioides

Lippia lycioides

Livistona australis

Livistona rotundifolia

Livistona saribus
Nome Botânico

\begin{tabular}{l}
\hline Lonchocarpus sericeus \\
Lonicera maakii \\
Lonicera ruprechtiana \\
Lophantera lactescens \\
Macfadyena unguis-cati \\
Machaerium milleflorum \\
Malpighia coccinea \\
Malvaviscus arboreus \\
Melaleuca leucadendra \\
Michelia champaca \\
Mimosa elengi \\
Mimosa verrucosa \\
Montanoa bipinnatifica \\
Myrcia sphaerocarpa \\
Myrciaria cauliflora \\
Myroxylon toluiferum \\
Myrtus rubra \\
Nectandra venulosa \\
Norantea brasiliensis \\
Ocotea odorifera \\
Orbignya speciosa \\
Paullinia elegans \\
Paulownia taiwaniana \\
Phoenix canariensis \\
Phoenix paludosa \\
Phoenix rupicola \\
Pimenta racemosa \\
Pinus michoacana \\
Piper ceanothifolium \\
Pithecelobium diversifolium \\
Pittosporum undulatum \\
Polyscias filicifolia \\
Pontederia cordata \\
Pseudobombax cyathophorum \\
Pterogyne nitens \\
Ptychosperma elegans \\
Punica granatum \\
Randia dumetorum \\
Ravenala madascariensis \\
Rhapis excelsa \\
Rhodotypos kerrioides \\
Sabal minor \\
Salix babylonica \\
Schinus terebenthifolius \\
Schotia brachypetala \\
Senna bicapsularis \\
Serjania orbicularis \\
Severinia buxifolia \\
Sideroxylum gardnerianum \\
Spiraea arguta
\end{tabular}


Tabela 5. Lista das espécies arbóreas e arbustivas que foram extintas do Parque no período estudado.

Nome Botânico

Spondias tuberosa

Stenolobium stans

Syagrus coronata

Syzygium jambos

Tabebuia alba

Tabebuia avellanede

Tabebuia flavescens

Tabebuia roseo alba

Tabernaemontana citrifolia

Thryallis glauca

Thuja occidentalis

\author{
Nome Botânico \\ Thuja orientalis \\ Tibouchina stenocarpa \\ Tipuana speciosa \\ Triphasia trifolia \\ Typha latifolia \\ Vangueria madagascariensis \\ Vernonia polyanthes \\ Vitex sellowiana \\ Yucca schottii \\ Yucca smalliana \\ Zanthoxylum latespinosum
}

Tabela 6. Lista das espécies arbóreas e arbustivas incorporadas ao Parque no período estudado.

\author{
Nome Botânico \\ Aloysia virgata \\ Anadenanthera colubrina \\ Anadenanthera peregrina \\ Aspidosperma cylindrocarpum \\ Aspidosperma olivaceum \\ Aspidosperma polyneron \\ Aspidosperma pyrifolium \\ Bauhinia blackeana \\ Blepharocalyx salicifolius \\ Bombacopsis glabra \\ Bombacopsis stenopetala \\ Caesalpinia leyostachya \\ Calycophyllum sprunceanum \\ Calyptrantes concinna \\ Campomanesia guazumaefolia \\ Cassia ferruginea \\ Cecropia pachystachya \\ Cedrella fissilis \\ Cedrella odorata \\ Centrolobium tomentosum \\ Cereus hildmanianus \\ Chamaecyparis funebris \\ Chrysophyllum gonocarpum \\ Chrysophylum marginatum \\ Citrus limon Burm F. \\ Coccotrinax sp \\ Cochlospermum ensigne \\ Copaifera langsdorfii \\ Coutarea hexandra \\ Crysophyllum marginatum \\ Diguetia lanceolata \\ Diospyros inconstans
}

\author{
Nome Botânico \\ Dracaena fragrans \\ Elaeis guineensis \\ Enterolobium contortisiliquum \\ Erythrina vellutina \\ Erythroxylum ambiggum \\ Erythroxylum buxus \\ Erythroxylum deciduum \\ Esembeckia febrifuga \\ Esenbeckia leiocarpa \\ Eucaliptus citriodora \\ Eugenia blastantha \\ Eugenia dodonaefolia \\ Eugenia involucrata \\ Eugenia jambos \\ Eugenia moraviana \\ Eugenia pluriflora \\ Eugenia tomentosa \\ Euphorbia continifolia \\ Euphorbia hermentiana \\ Ficus glabra \\ Ficus guaranitica \\ Galipea multiflora \\ Genipa infundibiliformis \\ Gochnatia polymorpha \\ Gochnatia velutina \\ Guapira opposita \\ Guarea guidonia \\ Guatteria sp \\ Guazuma ulmifolia \\ Hymenaea stilbocarpa \\ Jacaranda mimosaefolia \\ Jacaratia spinosa
}


Tabela 6. Lista das espécies arbóreas e arbustivas incorporadas ao Parque no período estudado.

Nome Botânico

Leucaena leucocephala

Lonchocarpus muehlbergian

Machaerium aculeatum

Machaerium nictitans

Machaerium stipitatum

Manihot grahamii

Manilkara zapota

Matayba eleagnoides

Methodorea migra

Mimosa caesalpiniaefolia

Miroxylon peruiferum

Myrcia cauliflora

Myrcia laruotteana

Myrcia ramulosa

Myrcia rostrata

Myrciaria cauliflora

Nectandra megapotamica

Pachystroma longifolium

Parapiptadenia rigida

Paxiuba syagrus

Peltophorum dubium

Peschiera fuchsiaefolia

Peschieria australis

Pisonia ambigua

Plinia glomerata

Polyandrococos caudescens

Pseudobombax grandiflorum

Psidium cattleianum

Pterocarpus violaceus

\author{
Nome Botânico \\ Randia armata \\ Rhamnidium elaeocarpum \\ Sebastianiana serrata \\ Securinega guaraiuva \\ Seguieria langsdorffii \\ Solanum erianthum \\ Solanum swartzianum \\ Spondias lutea \\ Spondias mombim \\ Sterculia chicha . \\ Syagrus oleracea \\ Tabebuia caraiba \\ Tabebuia crysotricha \\ Tabebuia heptaphylla \\ Tabebuia serratiflora \\ Tabebuia vellosoi \\ Tapirira marchiandii \\ Taxodium disthicum \\ Terminalia triflora \\ Thevetia peruviana \\ Tipuana tipu \\ Trichilea elegans \\ Trichilia pallida \\ Triplaris americana \\ Triplaris brasiliensis \\ Vitex montevidensis \\ Zanthoxylum chiloperone \\ Zanthoxylum hiemale
}

Tabela 7. Lista das espécies arbóreas e arbustivas que aparecem no levantamento de 1965 e no de 1991.

\section{Nome Botânico}

\begin{tabular}{l}
\hline Acrocomia aculeata \\
Albizzia lebbeck \\
Alchornea iricurama \\
Aleurites mollucana \\
Allophyllus edulis \\
Anadenanthera macrocarpa \\
Aspidosperma ramiflorum \\
Astronium graveolens \\
Attalea phalerata \\
Balfourodendrum riedelianum \\
Bauhinia forficata \\
Bougainvillea glabra \\
Bougainvillea spectabilis \\
Caesalpinia echinata \\
Caesalpinia ferrea
\end{tabular}

\section{Nome Botânico}

Caesalpinia gardneriana

Caesalpinia peltophoroides

Caesalpinia pulcherrima

Cariniana legalis

Cariniana strellensis

Caryota mitis

Caryota urens

Casearia silvestris

Ceiba erianthus

Centrolobium robustum

Cereus peruviana

Chlorophora tinctoria

Chorizia speciosa

Chrysophyllum ebenaceum

Coccoloba uvifera 
Tabela 7. Lista das espécies arbóreas e arbustivas que aparecem no levantamento de 1965 e no de 1991.

\begin{tabular}{l}
$\quad$ Nome Botânico \\
\hline Cocus nucifera \\
Coffea arabica \\
Cola acuminata \\
Colubrina glandulosa \\
Cycas circinalis \\
Delonix regia \\
Duranta repens \\
Entorolobium timbouva \\
Ervatamia coronaria \\
Eugenia brasiliensis \\
Eugenia uniflora \\
Ficus elastica \\
Ficus lyrata \\
Gallesia integrifolia \\
Garcinia cochinchinensis \\
Genipa americana \\
Grevillea robusta \\
Holocalix balansae \\
Hura crepitans \\
Hymenae stilbocarpa \\
Joannesia princeps \\
Lafoensia glyptocarpa \\
Lecythis pisonis \\
Ligustrum lucidum \\
Livistona chinensis \\
Luhea divaricata \\
Machaerium angustifolium \\
Machaerium villosum \\
Mangifera indica \\
Moquilea tomentosa \\
\end{tabular}

\begin{tabular}{l}
\multicolumn{1}{c}{ Nome Botânico } \\
\hline Murraya paniculata \\
Myracroduon urundeuva \\
Myroxylon peruiferum \\
Pachystroma iliciflorum \\
Patagonula americana \\
Pereskia grandifolia \\
Phoenix canariensis \\
Phoenix reclinata \\
Piptadenia gonocantha \\
Pittosporum tobira \\
Platypodium elegans \\
Plumeria rubra \\
Porcelia macrocarpa \\
Psidium guayava \\
Pterodon emarginatus \\
Roystonea oleracea \\
Roystonea regia \\
Samanea saman \\
Sapindus saponaria \\
Schyzolobium parahybum \\
Senna macranthera \\
Solanum argenteum \\
Syagrus romanzoffiana \\
Syzygium cuminii \\
Tabebuia impetiginosa \\
Trichilea catigua \\
Trichilea clausseni \\
Trichllia claussenii \\
Zanthoxylum rhoifolium \\
Zizyphus joazeiro
\end{tabular}

Propõe-se, portanto um manejo racional nos maciços estudados, para que haja um equilíbrio maior entre as espécies, através da retirada de árvores, de espécies que estão dominando tais como Johanesia princeps (Boleira), Holocalix balansae (Alecrimde-Campinas), Anadenanthera sp. (Angico), Myrcia laurotteana (Cambui), Casearina silvestris (Guaçatonga), Allophylus edulis (Chal-chal), Machaerium villosum (Jacarandápaulista), Aspidosperma ramiflorum (Guatambu), Rhamnidium aleocarpum (Saguaragi), além de várias espécies de palmeiras, dentre elas a Syagrus romanzoffiana (Jerivá) e algumas espécies de pinheiros. 
Através dos dados analisados, pode se verificar que em 24 anos houve mudanças. O que poderá ocorrer nos próximos 100 anos, se nenhuma intervenção humana for feita?. A biodiversidade está diminuindo e estão se criando reboleiras de espécies únicas dentro dos maciços. Seria isto interessante? O parque, é fruto de um reflorestamento e não um remanescente de floresta nativa mas já possui relações entre espécies diferentes das que ocorrem dentro de um remanescente de mata. Além disso, as técnicas hoje conhecidas de reflorestamento, tais como, os processos sucessionais, agentes dispersores etc muito provavelmente, não foram previstos na implantação do projeto. Seria de extrema valia, para um estudo como este, se houvesse a relação de plantas utilizadas na época da implantação do projeto, ou ainda, se houvesse levantamento de todas espécies, tais como os citados neste trabalho, realizado em tempos anteriores.

\subsubsection{Espécies ornamentais de pequeno porte e floríferas}

Através de observações realizadas no levantamento de 1965 e em cadastro, realizado in loco, em agosto de 1998, montaram-se tabelas (Tabelas 8 e 9 respectivamente), com as espécies de plantas ornamentais de pequeno porte (forrações, anuais, vivazes etc) presentes no Parque.

Tabela 8. Lista com as espécies ornamentais de pequeno porte, presentes no Parque em 1965, segundo levantamento florístico realizado.

\begin{tabular}{l}
\multicolumn{1}{c}{ Nome Botânico } \\
\hline Agapanthus africanus \\
Agave angustifolia \\
Agave attenuata \\
Allamanda cathartica \\
Aloe arborescens \\
Alpinia purpurata \\
Ananas sativus \\
Arundo donax \\
Aspargus \\
Aspargus plumosus \\
Begonia \\
Macfadyena unguis-cati \\
Coleus blumei \\
Cordyline australis \\
Cordyline strica \\
Cordyline terminalis
\end{tabular}

\begin{tabular}{l}
\multicolumn{1}{c}{ Nome Botânico } \\
\hline Cortaderia selloana \\
Cortaderia sellowana \\
Costus cylindricus \\
Crinum amabile \\
Cycas circinalis \\
Ficus pumila \\
Hedychium coronarium \\
Heliconia bansai \\
Heliconia hirsuta \\
Homalocladium platycladum \\
Monstera deliciosa \\
Ophiopogom japonicus \\
Pandanus utilis \\
Philodendron selloum \\
Rhoeo discolor
\end{tabular}


Tabela 8. Lista com as espécies ornamentais de pequeno porte, presentes no Parque em 1965, segundo levantamento florístico realizado.

\section{Nome Botânico}

Russelia equisetiformis

Salvia splendens

Sansevieria thyrsiflora

Setcresia purpurea

\section{Nome Botânico}

Wedelia chrysostephana

Wedelia paludosa

Zebrina pendula

Tabela 9. Lista com as espécies ornamentais de pequeno porte, presentes no Parque em agosto 1998, através de cadastro realizado in loco.

Zebrina pendula

Ficus pumila

Sansevieria trifasciata Hort ex Pain.

Monstera deliciosa

\section{Nome Botânico}

Hemalocladium platycladum

Maranta leuconeura

Dracaena deremensis

Agave americana

Analisando-se as tabelas acima, pode-se notar que houve diminuição no número de espécies, principalmente de floríferas, que é uma importante característica do Estilo Inglês de Paisagismo. Propõe-se o plantio de espécies ornamentais, em locais estratégicos, de preferência plantas rústicas, que não necessitem de manejo intenso.

Nota-se porém, em local onde pelas características observadas no Estilo Inglês de Paisagismo, é de extrema importância a presença de floríferas, ou seja, ao redor e fronteiriço ao prédio que se destaca dentro do jardim (no caso o Prédio Central), ao redor nota-se a presença de floríferas e seus constantes tratos culturais. Faltam, portanto, a introdução de canteiros de flores/ornamentais, ao longo das ruas e em locais de grande destaque, como as bordas internas dos maciços e os cruzamentos de ruas.

\subsection{Linhas de Visadas Imaginárias}

Conforme comentado, várias características propostas no projeto original do Parque, foram modificadas, porém, para propor a volta de todas as características planejadas, muito deveria ser feito, inclusive a remoção de um Prédio drástica redução nos maciços, o que seria totalmente inviável. Iremos então, propor a volta de apenas algumas características que sejam viáveis, tais como a desobstrução das linhas de visadas imaginárias. 
Das 10 linhas de visada imaginárias, propostas pelo paisagista no projeto do Parque, podemos observar a existência de 6 linhas obstruídas (linhas vermelhas) pelos maciços de número 17, 18, 24 e o Prédio da Seção de Alunos (Figura 37) e 4 linhas desobstruídas.

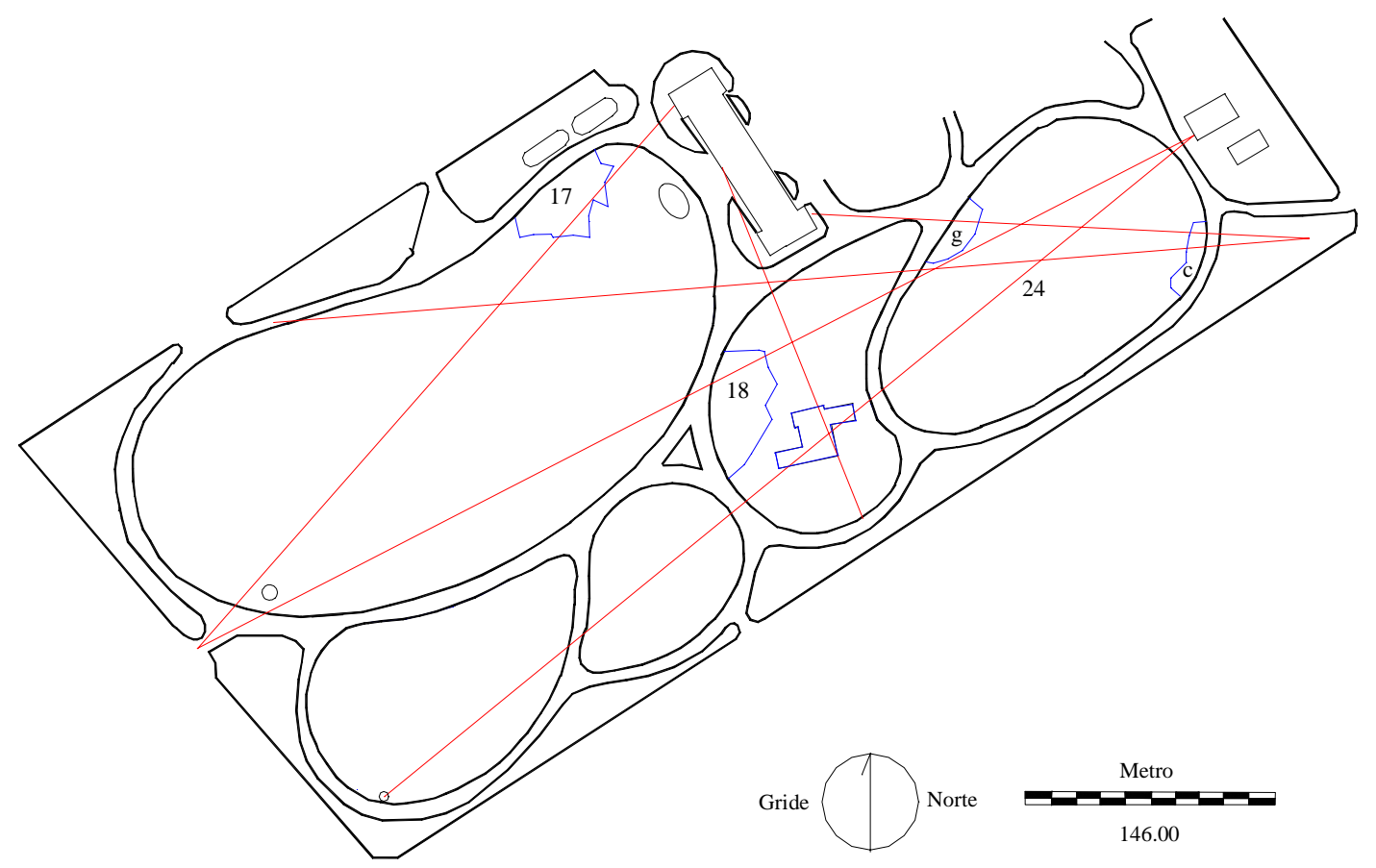

Figura 37. Imagem mostrando as linhas de visada obstruídas (linhas vermelhas), os maciços 17, 18, os mini-maciços 24c e 24g e o Prédio da Seção de Alunos, que interrompem as linhas.

Observando-se a Figura 37, podemos notar que o maciço 17, obstrui a linha que vai do Portão Principal do Parque até a parte frontal-esquerda do Prédio Central. O maciço de número 18, obstrui a linha que vai do Prédio da Microscopia Eletrônica até o Portão Principal e o maciço 24, que é formado por vários mini-maciços, apenas dois deles interrompem visadas. O de número 24g, localizado próximo à bica d’água, interrompe a linha que vai da rua que fica ao lado do Serviço Odontológico, até a Alameda Principal. O outro, de número 24c, próximo ao Prédio do Serviço Odontológico, interrompe a linha que vai da rua ao lado do Serviço Odontológico, até a parte traseira-direita do Prédio Central. 
Estes dados mostram, mais uma vez, a necessidade de se realizar um manejo mais adequado do Parque, principalmente nos maciços, citados anteriormente, que devem, seguindo orientação, ter transplantadas as mudas e, as árvores de grande porte, em estado terminal, serem retiradas e não replantadas no mesmo local. As árvores sem grande expressão e as existentes em grande número, devem também ser retiradas. Quanto as linhas de visadas interceptadas pelo Prédio da Seção de Alunos, fica impossibilitada as suas desobstruções.

No maciço 17, através de observações in loco, as árvores que formam a "cortina” que interrompe a visada, são pertencentes basicamente a três espécies: 12 plantas de Rhamnidium elaeocarpum (Saguaragi-amarelo), 10 Allophilus edulis (Chal-chal) e 4 Peschiera fuchsaefolia (Leiteiro). Somam-se a elas: 1 Tipuana tipu (Tipuana), 2 Bauhinias (Bauhinias) e 1 Casearina sylvestris (Guaçatonga). Deve-se lembrar que estas espécies formam praticamente o restante do maciço, devendo portanto, serem retiradas, pois, as árvores, são de pouca importância, do ponto de vista de coleção botânica e de preciosidade e se apresentam em grande número na região. O mini-maciço 24 g, é formado por árvores das espécies Spondias mombim (Caja-mirim), Caesalpinia ferrea (Pau-ferro), Ficus elastica (Ficus), Caesalpinia echinata (Pau-brasil) e Calycophyllum spruceanum (Pau-mulato) onde cada uma, é representada por apenas um indivíduo. Por se tratarem de espécies “nobres” e/ou com poucos indivíduos, no restante do Parque a proposta é que as mesmas sejam mantidas, até que pereçam deixando para o futuro a desobstrução da visada que vai do Prédio da Microscopia Eletrônica até a lateral do Prédio Principal. As mesmas, não deverão ser replantadas no local. Já no minimaciço 24c, basta podar alguns galhos das árvores nele presentes e limpar o sub-bosque, que as linhas de visadas já estarão desobstruídas, não causando, portanto, maiores danos à vegetação.

No maciço 18, a intervenção também é bastante pequena, sendo o que está interrompendo a linha de visada, é uma linha de arbustos do gênero Dombeya, que pode ser retirada e transplantada em outro local do Parque, ou até mesmo fora dele.

Ressalta-se ainda, a urgência de manejo dos outros maciços existentes no Parque, em relação à contenção do crescimento, em área, seja pela proximidade dos mesmos às 
linhas de visada, casos dos maciços 10, 13, 14 e 21, ou para conter uma maior descaracterização do Parque.

Quanto ao Prédio da Seção de Alunos, é lamentável a escolha daquele local para sua construção, no tocante à descaracterização do projeto original, vindo, entre outras coisas, obstruir duas linhas de visada, sendo uma que vai do Prédio da Microscopia Eletrônica, até o Coreto (não construído) e uma outra, que vai da entrada para o Parque (mudada de local) da Estrada do Monte Alegre, até a frente do Prédio Central.

Portanto, com a prática de manejo dos maciços arbóreo/arbustivos, podem-se recuperar, três linhas de visada, ficando uma outra para o futuro, quando as árvores do mini-maciço 24g perecerem. 


\section{CONCLUSÕES}

Com o material e os métodos empregados, os resultados obtidos, analisados e interpretados permitiram tirar as conclusões apresentadas a seguir:

1) os maciços do Parque da ESALQ, poderiam ter sido submetidos à manutenção desde 1927, para manter a conformação, características e efeitos propostos pelo paisagista Arsenio Puttemans. Porém, não é o que os dados mostram, pois os mesmos, tiveram um crescimento demasiado e desordenado, descaracterizando assim, a conformação do projeto original. A área de cobertura arbórea/arbustiva de aproximadamente $30.000 \mathrm{~m}^{2}$, foi em muito superada em 1945 (data da fotografia mais antiga obtida), sendo a mesma de $40.576 \mathrm{~m}^{2}$ e em 1995 (último vôo), essa medida passa a 77.221 $\mathrm{m}^{2}$;

2) realizar levantamentos florísticos e fitossociológicos periódicos nos maciços arbóreo/arbustivos, com locação topográfica dos indivíduos, a fim de se observarem, se as mudanças propostas surtiram o efeito esperado, além de manter o banco de dados das espécies que compõem os maciços arbóreo/arbustivos, atualizados, conforme citado por Leitão Filho (1982);

3) o software IDRISI, mostrou-se eficiente na obtenção da medição das áreas e na caracterização dos maciços arbóreo/arbustivos;

4) as fotografias aéreas são importantes no estudo pois, permitirão com o uso de um software adequado, completar o projeto original. 
5) das dez linhas de visadas imaginárias propostas pelo paisagista, no projeto original, seis estão interrompidas, sendo quatro delas, interrompidas por maciços arbóreo/arbustivos e duas, pelo Prédio da Seção de Alunos;

6) das seis linhas de visada, interrompidas, quatro delas poderão ser desobstruídas, através de práticas simples de manejo, que são:

- eliminação de parte do maciço de número 17;

- limpeza no sub-bosque do maciço de número 18 e mini maciço 24c;

- no mini-maciço de número 24g, deve-se evitar a introdução de árvores no mesmo e aguardar que as árvores que o constituem, pereçam;

- as outras duas linhas, interrompidas pelo Prédio da Seção de Alunos, ficam impossibilitadas de serem desobstruídas;

7) devem-se realizar desbastes de árvores de espécies que estiverem desequilibrando a biodiversidade nos maciços, conforme já comentado na página $77, \S 1^{\circ}$ do item Resultados e Discussão;

8) deverá ser evitado o plantio de árvores nos locais onde os maciços foram corrigidos;

9) devem-se fazer observações periódicas nas linhas de visadas e nos maciços arbóreo/arbustivos do Parque, no tocante à área dos mesmos, principalmente no seu perímetro, evitando que eles voltem a crescer;

10) merecem urgência as revisões dos maciços de números 10, 13, 14 e 21, pois os mesmos já tangenciam algumas linhas de visada;

11) no interior dos maciços, devem ser introduzidas árvores de espécies que foram extintas no período estudado (Tabela 5 na página 73 e seguintes), observando a fitossociologia de cada espécie, para auxiliar a sua distribuição, conforme os relatos 
de Gandolfi (1991). Devem ser introduzidas também, espécies que sejam de interesse, para estudos e pesquisas e ainda, plantas de espécies presentes no Parque, representadas por apenas um indivíduo e que, o mesmo, esteja danificado, doente, praguejado ou com idade avançada;

12) deverão ser implementadas, junto à Administração do Campus, leis que orientem a construção de prédios na área do Parque;

13) deverão ser introduzidas plantas ornamentais de pequeno porte em locais de destaque, tais como: borda de maciços, beira de ruas etc e manter as já existentes ao redor do Prédio Central conforme os preceitos de Bellair \& Bellair (1939);

14) deverão ser introduzidas novas espécies arbóreas em áreas que ainda estão disponíveis como por exemplo, os jardins do Pavilhão de Engenharia, cujos canteiros já estão delimitados.

\section{SUGESTÕES}

1) propõe-se comparar os levantamentos da Mata do Piracicamirim e da Mata da Pedreira, com os levantamentos realizados no Parque da ESALQ, para verificar se há alguma coincidência;

2) realizar estudo de dispersão de sementes, para tentar entender as grandes mudanças ocorridas na florística dos maciços arbóreo/arbustivos do Parque e até, para embasar estudos futuros.

3) devido ao sucesso da metodologia utilizada neste estudo, propõe-se a realização de estudo semelhante em outros Parques; 
4) poderá se utilizar do software IDRISI, para dispor topográficamente as árvores dentro de cada maciço, para se estudar com mais rigor, a florística e a fitossociologia das espécies presentes no Parque;

5) na proposição de um parque, deverão ser observadas algumas características, que não foram utilizadas no Parque estudado, que são:

- observações, quanto ao diâmetro da copa das árvores que deverão ser plantadas nos maciços, principalmente na sua borda, com relação à distância do local de plantio da mesma, à linha que define o maciço.

- observações quanto à sucessão das espécies utilizadas na implantação;

- intervenções periódicas corrigindo eventuais erros na conformação dos maciços, bem como na florística e na fitossociologia dos mesmos.

- mapeamento das espécies por maciço;

6) elaborar projetos paisagísticos detalhados das áreas da Escola respeitando o Estilo Inglês de Paisagismo. 


\section{REFERÊNCIAS BIBLIOGRÁFICAS}

ALVES, D.S. Sistema de informação geográfica. In: RODRIGUES, M. (coord.) Geoprocessamento. São Paulo: EDUSP, 1990. p.66-67.

AVERY, T.E. Interpretation of aerial photographs. 3. ed. Minneapolis: Burgess Publ., 1978. 392p.

BARRETO, R. G. Levantamento das espécies de Commelinaceae R. Br. Nativas do Brasil. São Paulo: EDUSP, 1997. 490p. Tese (Doutorado) - Instituto Biológico, Universidade de São Paulo.

BATISTA, E. A. Levantamentos fitossociológicos aplicados à vegetação de cerrado, utilizando-se de fotografias aéreas verticais. Piracicaba, 1982. 86p. Dissertação (Mestrado) - Escola Superior de Agricultura "Luiz de Queiroz", Universidade de São Paulo.

BELLAIR, G.A.; BELLAIR, P.A. Parcs et jardins. Paris: Encyclopédie Agricole, 1939. 348p.

CALIJURI, M.L.; ROHM, S. Sistema de informação geográfica. Viçosa: UFV, 1993. 42p.

CAMPOS, S.A. Áreas verdes de Piracicaba. Anais da Escola Superior de Agricultura "Luiz de Queiroz", v.48, p.71-107, 1991. 
CATHARINO, E.L.M. Estudos fisionômicos, florísticos e fitossociológicos em matas residuais secundárias no município de Piracicaba-SP. Campinas, 1989. 190p. Dissertação (Mestrado) - Universidade Estadual de Campinas.

COUTO, H.T.Z. Métodos de amostragem para avaliação de árvores de ruas. In: CONGRESSO BRASILEIRO DE ARBORIZAÇÃO URBANA, 2o, São Luis, 1994. Anais. São Luis: Sociedade Brasileira de Arborização Urbana, 1994. p. 169-179.

CRUZ, A.M.R.; CAMARA, M.C. Levantamento arbóreo da Cidade de São Paulo. São Paulo, 1976.

DEMATTÊ, M.E.S.P. Princípios de paisagismo. Jaboticabal: Funep, 1997. 104p. (Série Paisagismo, 1).

EASTMAN, J.R. (Coord.) User`s guide of IDRISI 1.0 for windows. Clark University, 1995. 178p.

ENGEL, V.L.; POGGIANI, F. Estudo fenológico das principais espécies arbóreas plantadas no Parque da Escola Superior de Agricultura “Luiz de Queiroz” em Piracicaba-SP. O Solo, v.77. n.1/2, p.42-56 jan./dez. 1985.

ENGEL, V.L.; MORAIS, A.L.; POGGIANI, F. Guia de localização e reconhecimento das principais espécies arbóreas do Parque da ESALQ. Piracicaba: FEALQ, 1985. 226p.

GANDOLFI, S. Estudo florístico e fitossociológico de uma floresta residual na área do Aeroporto Internacional de São Paulo, município de Guarulhos, S.P. Campinas, 1991. 232p. Dissertação (Mestrado) - Universidade Estadual de Campinas 
GOLDEMBERG, R.; RODRIGUES, R.R.; ESSOE, B. Levantamento florístico e fitossociológico dos canteiros do Parque da Escola Superior de Agricultura "Luiz de Queiroz". Anais da Escola Superior de Agricultura "Luiz de Queiroz", v.48, p.71-107, 1991.

GOODWIN, D.W. A street tree inventory for Massachusetts using a Geographic Information System. Journal of Arboriculture, v.22, n.1, p.19-28, 1996.

GOOSEN, D. Interpretation de fotos aereas y su importancia en levantamiento de suelos. Roma: FAO, 1968. 58p. (FAO. Boletim sobre Suelos, 6).

GREY, G.W.; DENEKE, F.J. Urban forestry. New York: John Wiley, 1978. 279p.

GUO, Q.; XU, D.Y.; YAN, H. et al. Study on the impacts of climate changes on the distribution of Pinus tabulaeformis in China. Scientia Silvae Sinicae, v.31, n.5, p.393-402, 1995./Resumo em CAB Abstracts em CD-ROM - 1995/.

HEINSDIJK, D. Interpretação florestal de fotografias aéreas. Publicação do Serviço Florestal de Suriname, n.13 p.234-257, 1952.

HENDERSON, A.; GALEANO, G.; BERNAL, R. Fields guide to the palms of the Americas. New Jersey: Princeton University Press. 1995. 416p.

JORGENSEN, E. Towards are urban forestry concept. Ottawa: Forestry Service, 1974. 14p.

KAGEYAMA, P.Y. Estudo para implantação de matas ciliares de proteção na Bacia Hidrográfica do Passa Cinco, visando a utilização para abastecimento público. Piracicaba: FEALQ; DAEE; ESALQ, 1986. 34p. 
KAMARUZAMAN, J.; MOHD-RASOL, M.A. Satellite remote sensing of deforestation in the Sungai Buloh Forest Reserve. International Journal of Remote Sensing. v.16, n.11, p.1981-1997, 1995. / Resumo em CAB Abstracts em CD-ROM - 1995.

LEITÃO FILHO, H.F. Aspectos taxonômicos das florestas do Estado de São Paulo. In: CONGRESSO NACIONAL DE ESSÊNCIAS NATIVAS, 1., Campos do Jordão, 1982. Anais. Silvicultura em São Paulo, v.16A, pt.1, p.197-206, 1982.

LIMA, A.M.L.P. Nosso Parque faz 80 anos. Revista da ADEALQ, v.10, n.6, p.20-22, 1987.

LOCH, C. A interpretação de imagens aéreas: noções básicas e algumas aplicações nos campos profissionais. 2.ed. Florianópolis: Editora da UFSC, 1989. 119p. (Série Didática).

LORENZI, H. Árvores brasileiras. Manual de identificação e cultivo de plantas arbóreas nativas do Brasil. Nova Odessa: Editora Plantarum, 1992. 368p.

LORENZI, H. Árvores brasileiras. Manual de identificação e cultivo de plantas arbóreas nativas do Brasil. 2.ed. Nova Odessa: Editora Plantarum, 1998. 368p.

LORENZI, H.; SOUZA, H. M.; COSTA, J. T. de M. et al. Palmeiras no Brasil. Nativas e exóticas. Nova Odessa: Editora Plantarum, 1996. 320p.

LORENZI, H., SOUZA, H. M. Plantas ornamentais no Brasil. Arbustivas, herbáceas e trepadeiras. Nova Odessa: Editora Plantarum. 1995. 736p.

MABBERLEY, D. J. The plant-book, a portable dictionary of the vascular plants. 2.ed. New York: Cambridge University Press. 1997. 858p. 
MACHIN, J.; NAVAS, A. Land evaluation and conservation of semiarid agrosystems in Zaragoza (NE Spain) using an expert evaluation system and GIS. Land Degradation and Rehabilitation, v.6, n.4, p.203-214, 1995./ Resumo em CAB Abstracts em CDROM - 1995/.

MENDONÇA, J.F.; SANTOS, J.R.; LUCHT, P.H., et al. Aplicações de sensoriamento remoto em agronomia e floresta. São José dos Campos: INPE, 1980. 318p.

MERCADAL, F.G. Parques y jardines: su historia e sus trazados. Madrid: Afrodisio Aguado, 1949. v.4, 299p.

MESQUITA, A. de L, Revisão taxonômica do Gênero Enterolobium Mart. (Mimosoideae) para a região neotropical. Recife: UFRP. 1990. 222p. Dissertação (Mestrado) - Universidade Federal Rural de Pernambuco.

MILLER, R.W. Urban forestry: planning and managing urban greenspaces. 2. ed. Englewood Cliffs: Prentice Hall, 1997. 502p.

MONTENEGRO, H.W.S. A arte de projetar jardins. Piracicaba: FEALQ, 1983. 134p.

RABBEN, E.L. Fundamentals of photointerpretation. In: AMERICAN SOCIETY OF PHOTOGRAMMETRY. Manual of photographic interpretation. Washington, 1960, p.99-186.

RANZANI, G. Manual de levantamento dos solos. São Paulo: EDUSP, 1965. 112p.

REIS, J.C. Proposição metodológica para estudo e mensuração do processo de assoreamento de reservatórios, utilizando sistema de informação geográfico. Viçosa, 1995. 119p. Dissertação (Mestrado) - Universidade Federal de Viçosa. 
ROCHA, J.S.M. de. Manual de interpretação de aerofotogramas. Santa Maria: Universidade Federal de Santa Maria, 1986. 58p.

RODRIGUES, R. R.; GANDOLFI, S. Recomposição de florestas nativas: princípios gerais e subsídios para uma definição metodológica. Revista Brasileira de Horticultura Ornamental, v.2, p.4-15, 1996.

ROMERO, R. Florística da família Melastomataceae na planície litorânea de Picinguaba, Município de Ubatuba, Parque Estadual da Serra do Mar, São Paulo. Rio Claro: UNESP. 1993. 178p. Dissertação (Mestrado) - Instituto de Biociências, Universidade Estadual Paulista.

ROSALEN, D.L. Estudo do processo de captação de imagens aplicado à fotogrametria digital. São Carlos, 1997. 139p. Dissertação (Mestrado) - Escola de Engenharia de São Carlos - Universidade de São Paulo.

ROSSI, L. A flora arbóreo-arbustiva da Mata da Reserva da Cidade Universitária "Armando de Salles Oliveira", São Paulo. São Paulo:USP, 1987. 270p. Dissertação (Mestrado) - Instituto de Biociências, Universidade de São Paulo.

SALVADOR. Prefeitura Municipal. Áreas verdes e espaços abertos. Salvador: OCEPLAN; PLANDURB, 1978. 211p.

SANTOS, M.C. Manual de jardinagem. 2.ed. Rio de Janeiro: Freitas Bastos, 1975. 456p.

SÃO PAULO (Estado). Secretaria do Meio Ambiente. Vegetação significativa no Município de São Paulo. São Paulo, 1988. 560p. (Série Documentos). 
SARTORI, L. B. S. O Gênero Machaerium Pers. (Leguminosae - Papilionidae Dalbergieae) no Estado de São Paulo. Campinas: UNICAMP, 1994. 101p. Dissertação (Mestrado) - Instituto de Biologia, Universidade Estadual de Campinas.

SCHREUDER, G.F. Manual de fotogrametría forestal. . Turrialba: IICA, 1963. 91p.

SETZER, J. Contribuição para o estudo do clima do Estado de São Paulo. D.E.R. São Paulo. IX a XI: 237p. 1946. (separata).

SILVEIRA, A.B. Tipificação da cobertura vegetal da região oriental do Mato Grosso do Sul, área do reservatório da Usina Hidrelétrica Engo Sérgio Motta, através de imagens Landsat/TM. Três Lagoas, 1999. 60p. Monografia de Graduação - Departamento de Ciências Naturais, Universidade de Mato Grosso do Sul.

SOUZA, C. S. Scrophilariaceae da Serra do Cipó, Minas Gerais, Brasil. São Pulo: USP. 1990. 339p. Dissertação (Mestrado) - Departamento de Botânica, Universidade de São Paulo.

SPURR, S.H. Aerial photographs in forestry. New York: The Ronald Press, 1948. 340p.

TAKAHASHI, L.Y. Arboriação urbana: inventário. In: CONGRESSO BRASILEIRO DE ARBORIZAÇÃO URBANA, 2o, São Luis 1994, Anais. São Luis: Sociedade Brasileira de Arborização Urbana, 1994. p.193-200.

TOZZI, A. M. G. de A. Estudo taxonômico dos Gêneros Lonchocarpus Kunth e Deguelia Aubl. No Brasil. Campinas: UNICAMP. 1989. 341p. Tese (Doutorado) Universidade Estadual de Campinas, Departamento de Biologia Vegetal.

USTERI, A. Guia botânico da Praça da República e do Jardim da Luz. 1919. 
VASCONCELLOS, P.W.C. de O marco geográfico da ESALQ. In: ESCOLA SUPERIOR DE AGRICULTURA "LUIZ DE QUEIROZ". ESALQ 75: 75 anos a serviço da Pátria. Piracicaba, 1976. p.94

VASSÃO, F.; SOARES, A. Paisagismo: edição especial em vídeo da Revista Natureza. (vídeo). Direção geral de Oliveira, R.G.; roteiro de R. Piazentin,; coordenação de produção de C.C. Módena. São Paulo, 1996. vídeo, Editora Europa Multimídia, 22min.

WILDNER, M. Parque da ESALQ comemora 90 anos. Jornal da USP, v.9, n.318, p.7, 1995. 